UNIVERSIDADE DE SÃO PAULO

FACULDADE DE FILOSOFIA, LETRAS E CIÊNCIAS HUMANAS DEPARTAMENTO DE LETRAS CLÁSSICAS E VERNÁCULAS PROGRAMA DE PÓS-GRADUAÇÃO EM LETRAS CLÁSSICAS

MARIA CECÍLIA ALBERNAZ LINS SILVA DE ANDRADE

A Germania de Tácito: tradução e comentários

(versão corrigida - o exemplar original encontra-se disponível no CAPH (Centro de Apoio à Pesquisa Histórica) da FFLCH)

São Paulo 
UNIVERSIDADE DE SÃO PAULO

FACULDADE DE FILOSOFIA, LETRAS E CIÊNCIAS HUMANAS DEPARTAMENTO DE LETRAS CLÁSSICAS E VERNÁCULAS PROGRAMA DE PÓS-GRADUAÇÃO EM LETRAS CLÁSSICAS

\section{A Germania de Tácito: tradução e comentários}

(versão corrigida - o exemplar original encontra-se disponível no CAPH (Centro de Apoio à Pesquisa Histórica) da FFLCH)

Maria Cecília Albernaz Lins Silva de Andrade

Dissertação apresentada ao Programa de PósGraduação em Letras Clássicas do Departamento de Letras Clássicas e Vernáculas da Faculdade de Filosofia, Letras e Ciências Humanas da Universidade de São Paulo, para obtenção do título de mestre.

Orientador: Prof. Dr. Breno Battistin Sebastiani

São Paulo 
Nome: ANDRADE, Maria Cecília Albernaz Lins Silva de

Título: A Germania de Tácito: tradução e comentários

Dissertação apresentada ao Programa de Pós-Graduação em Letras Clássicas do Departamento de Letras Clássicas e Vernáculas da Faculdade de Filosofia, Letras e Ciências Humanas da Universidade de São Paulo, para obtenção do título de mestre.

Aprovado em:

Banca Examinadora 


\title{
RESUMO
}

Esta dissertação apresenta versão para o vernáculo do texto latino de Germania, obra trazida a lume em 98 d. C. pelo historiador Tácito e que compõe o conjunto das opera minora desse autor. Tal tradução é acompanhada do texto em latim e de notas para justificar determinada opção de versão, ante outras possibilidades de leitura da mesma palavra/passagem. A seguir, são tecidos comentários sobre a composição genérica de Germania, verificando as características que permitem inseri-la na tradição etnográfica e periegética e o contato com outros gêneros literários, mas também sobre a debatida questão da interpretação dessa obra única na literatura romana.

Palavras-chave: Germania, Tácito, tradução, historiografia, etnografia

\begin{abstract}
This dissertation presents a version in Portuguese of the Latin text of Germania, which was brought out in 98 a. D. by the historian Tacitus and integrates the opera minora of that author. This translation is accompanied by the Latin text and notes that justify such version option in face of other readings of the same word/passage. Next, commentaries about the generical composition of Germania are made, verifying the caracteristics that allow insert it in the ethnographic and periegetic tradition and the contact with other literary genders, but also about the debated question of the interpretation of this unique work in the Roman literature.
\end{abstract}

Keywords: Germania, Tacitus, translation, historiography, ethnography 
Familiaribus 


\section{AGRADECIMENTOS}

Ao Prof. Dr. Breno Battistin Sebastiani, pela orientação e paciência dispensada a mim. Obrigada por não abandonar quem eu mesma já teria abandonado.

À banca, composta pelo Prof. Dr. Pablo Schwartz Frydman e pela Profa. Dra. Corassin, por haver aceitado participar da qualificação e pela colaboração inestimável que deram à pesquisa com suas sugestões.

À biblioteca da Universität Basel na Suíça, especialmente à Frau Hildebrandt, pela atenção e ajuda que me forneceram. Modelo de eficiência e educação.

A minha família, por ficar sempre ao meu lado.

A meus amigos e colegas do latim, por estarem dispostos a me apoiar quando eu precisar.

A Alice Miyazaki, Magaly Negrisoli, Marcele Souto, Márcia Medeiros e Rosangela Gutierrez, pelo apoio. E, em especial, ao Ju, pela compreensão e afeto. 


\section{SUMÁRIO}

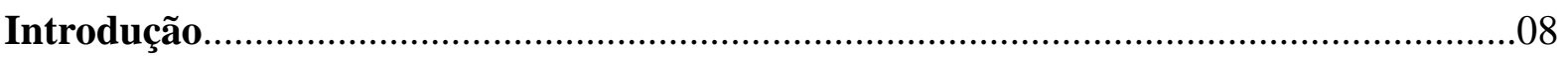

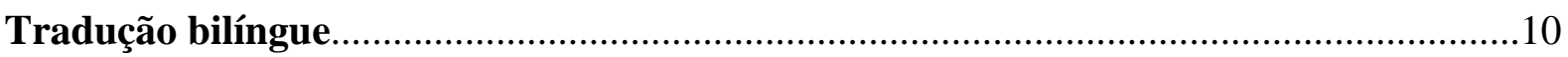

\section{Comentários}

Capítulo I. Sobre a construção da monografia etnográfica em Germania

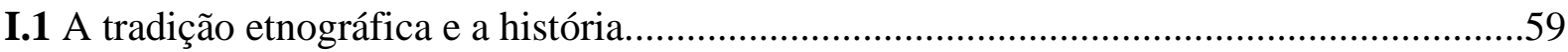

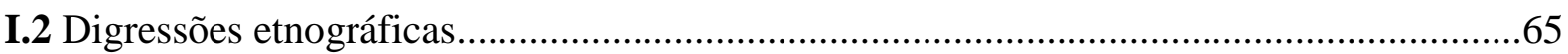

I.3 Da estruturação da monografia etnográfica em Germania .............................................77

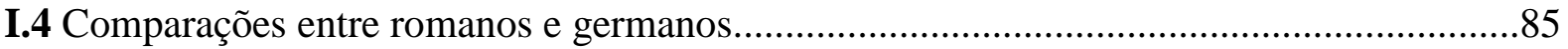

Capítulo II. Sobre a escrita periegética em Germania

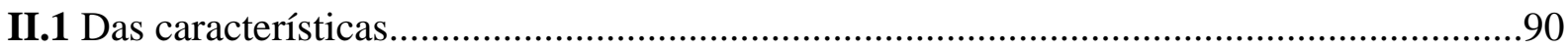

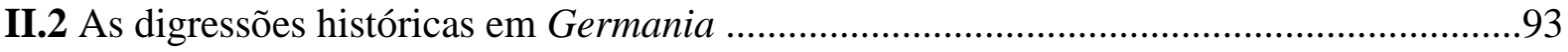

Capítulo III. A Germania como um todo

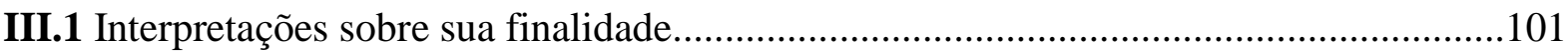

III.2 Gemania e Agricola: um programa comum...........................................................109

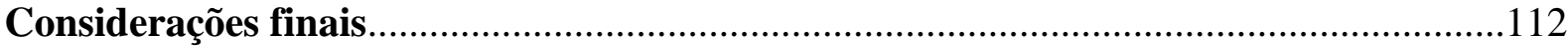

Bibliografia. 


\section{INTRODUÇÃO}

Esta dissertação compõe-se de nossa tradução do texto De origine et situ Germanorum ou simplesmente Germania, datada de 98 d.C., de Cornélio Tácito acrescida de notas filológicas e posterior estudo que discute a presença nesta obra de certas espécies e expedientes historiográficos e até mesmo de outros gêneros, como a épica, e a maneira como são trabalhados por Tácito, de modo a refletir sobre sua constituição genérica.

Nossa versão para o vernáculo é acompanhada do texto latino de Germania tal como estabelecido por Koestermann (1964), edição escolhida por apresentar detalhado aparato crítico. Pela peculiaridade da escrita de Tácito, marcada pela concisão amiúde derivada de elipses, pela abundância e variedade de figuras, aliterações e construções próprias dos estudos retóricos de sua época (OAKLEY, 2009), optamos por adotar como critério de tradução a preservação, no texto português, destes traços característicos. Este procedimento, entretanto, não logrará êxito quando o entendimento puder ser prejudicado. As notas elaboradas visam expor diferentes possibilidades de leitura de determinadas passagens conforme casos apontados e discutidos em bibliografia auxiliar, implicando discussão de possibilidades de tradução.

O estudo que segue a tradução tem por referência o esquema analítico de Karl Trüdinger (1918, p. 148), que divide Germania em duas metades: a primeira, que vai do parágrafo 1 ao 27, trata brevemente dos aspectos geográficos da região, discute sobre a origem da gente germana e apresenta suas características e costumes como se compusesse um grande e homogêneo grupo; a segunda, que vai de 28 a 46, trata de cada nação germana em particular, discorrendo sobre suas peculiaridades. Este estudo que apresentaremos é composto por comentários separados em três capítulos. No primeiro deles buscamos recuperar a tradição etnográfica desde a antiguidade grega até o século I d. C. para investigarmos em que medida e 
de que maneira Tácito se insere nessa tradição, sem a intenção de determinar quais foram suas fontes; no segundo, trataremos da composição da segunda metade de Germania e no terceiro falaremos sobre as interpretações dadas a esta obra de Tácito e de que forma a questão genérica está presente nesta discussão e sobre a Germania integrar com Agricola um programa comum. 


\section{TRADUÇÃO}

1. Germania omnis a Gallis Raetisque et 1 . Toda a Germânia está separada dos gauleses, Pannoniis Rheno et Danuvio fluminibus, a retos e panônios pelos rios Reno e Danúbio, e dos Sarmatis Dacisque mutuo metu aut montibus sármatas e dácios pelo medo mútuo e pelas separatur: cetera Oceanus ambit, latos sinus et montanhas. O Oceano circunda as demais insularum inmensa spatia complectens, nuper regiões, abarcando amplas baías e vastidões cognitis quibusdam gentibus ${ }^{1}$ ac regibus, quos insulares, das quais algumas gentes e reis se bellum aperuit. Rhenus Raeticarum Alpium tornaram recentemente conhecidos, pois a guerra inaccesso ac praecipiti vertice ortus, modico os revelou. O Reno, que nasce do cimo flexu in occidentem versus septentrionali inacessível e escarpado dos Alpes réticos, depois Oceano miscetur. Danuvius molli et clementer de se curvar um pouco para ocidente, deságua no edito montis Abnobae iugo effusus plures Oceano setentrional. Já o Danúbio, a espraiar-se populos adit, donec in Ponticum mare sex brandamente modesto do elevado cume da meatibus erumpat; septimum os paludibus montanha Ábnoba, percorre mais povos, até que hauritur.

$$
\begin{aligned}
& \text { se precipita no mar Pôntico por seis } \\
& \text { embocaduras; a sétima é sorvida pelos pântanos. }
\end{aligned}
$$

2. Ipsos Germanos indigenas crediderim 2. Quanto aos próprios Germanos, eu os julgaria minimeque aliarum gentium adventibus et nativos e de forma alguma imiscuídos aos que hospitiis mixtos, quia nec terra olim, sed vêm de outras gentes, porque outrora aqueles que classibus advehebantur qui mutare sedes desejavam mudar de moradia lá chegavam não

\footnotetext{
${ }^{1}$ Gerber e Greef (1962) dizem que “"natio' partem significat, 'gens' amplectitur” (p. 494); em Germania, gens remeteria à totalidade dos povos germanos, enquanto natio corresponderia a cada povo germano em particular. Entretanto, eles afirmam sobre a acepção de gens nesse primeiro parágrafo de Germania que " "natio' idem quam 'gens"” (p. 494), então gens assume a mesma significação de natio. Apesar disso, optamos por manter a versão de gens por "gente", para acompanhar a opção vocabular do texto latino. Outrossim é atribuída a mesma significação a gens em: 27,$10 ; 38,2 ; 13,15 ; 37,4 ; 43,10 ; 10,19 ; 30,5 ; 31$, $9 ; 33,8 ; 2,2 ; 39,10 ; 38,5 ; 29,9 ; 35,3 ; 38,2 ; 44,2 ; 45,7 ; 45,30 ; 28,7 ; 15,9 ; 36,8 ; 21,6 ; 38,7 ; 41,6 ; 25$, $10 ; 28,4 ; 34,2$.
} 
quaerebant, et inmensus ultra utque sic dixerim por terra, mas em naus. Além disso, o imenso e, adversus Oceanus raris ab orbe nostro navibus por assim dizer, oposto Oceano é visitado por aditur. quis porro, praeter periculum horridi et poucos navios do nosso mundo. E quem, fora o ignoti maris, Asia aut Africa aut Italia relicta perigo do mar violento e desconhecido, deixaria a Germaniam peteret, informem terris, asperam Ásia, a África ou a Itália e dirigir-se-ia à caelo, tristem cultu aspectuque nisi si patria sit? Germânia, de aspecto tosco, clima rigoroso e Celebrant carminibus antiquis, quod unum apud desagradável para viver e mesmo para observar, a illos memoriae et annalium genus est, não ser que fosse sua pátria?

Tuistonem deum terra editum. ei filium Por meio de cantos antigos, que é a única

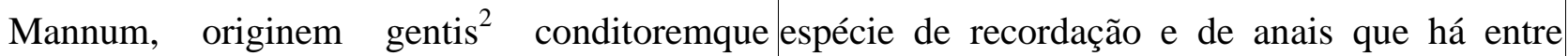
Manno tris filios assignant, e quorum nominibus eles, celebram o deus Tuistão, nascido da terra. proximi Oceano Ingaevones, medii Herminones, Atribui-se a ele um filho, Mano, origem e ceteri Istaevones vocentur. quidam, ut in licentia fundador da gente, e a Mano três filhos. E a partir vetustatis, pluris deo ortos plurisque gentis dos nomes destes, são chamados ingévones os appellationes, Marsos Gambrivios Suebos que habitam próximo ao Oceano, hermíones os Vandilios affirmant, eaque vera et antiqua da região central e istévones os demais. Alguns nomina. ceterum Germaniae vocabulum recens asseguram, conforme a licença que é dada à et nuper additum, quoniam qui primi Rhenum Antiguidade, haver mais filhos do deus e mais transgressi Gallos expulerint ac nunc Tungri, nomes de povos, marsos, gambrívios, suevos e tunc Germani vocati sint: ita nationis nomen, vândalos, e serem estes os nomes antigos e non gentis evaluisse paulatim, ut omnes primum verdadeiros. A denominação de "Germânia", ao a victore ob metum, mox etiam a se ipsis contrário, é recente e foi introduzida há pouco, invento nomine Germani vocarentur. porque os primeiros que atravessaram o Reno,

\footnotetext{
${ }^{2}$ Gens aqui trata dos germanos de uma maneira geral. Tal significado é dado a gens também em: 2, 20; 4, 3; 14,
} $9 ; 2,11 ; 2,15 ; 10,11 ; 19,4 ; 22,12$. Em todas essas passagens, gens foi traduzida por "gente". 


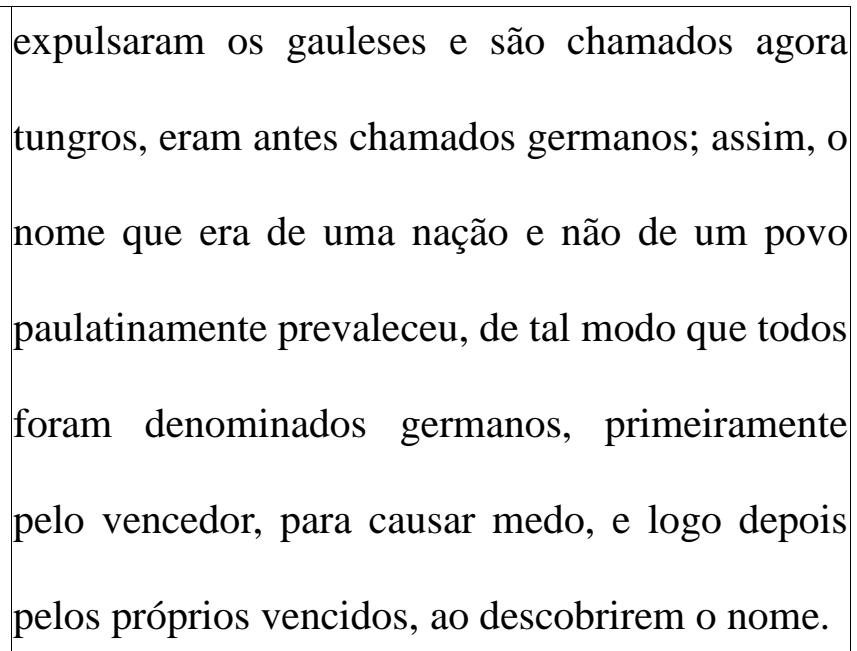

3. Fuisse apud eos et Herculem memorant, 3. Também recordam que Hércules viveu entre primumque omnium virorum fortium ituri in eles e, quando vão para a batalha, celebram-no proelia canunt. sunt illis haec quoque carmina, como o primeiro dentre os bravos varões. Eles quorum relatu, quem barditum vocant, também possuem cantos com cujo conteúdo, que accendunt animos, futuraeque pugnae fortunam denominam barditum, acendem os ânimos ao ipso cantu augurantur; terrent enim trepidantve, serem entoados, e por meio destes predizem a prout sonuit acies, nec tam voces illae quam sorte da batalha futura. Amedrontam ou abalamvirtutis concentus videntur. affectatur praecipue se, conforme o grito do exército, e isso mostra asperitas soni et fractum murmur, obiectis ad os não tanto a união de vozes quanto de valor. scutis, quo plenior et gravior vox repercussu Almejam a aspereza do som e um ruído irregular intumescat. ceterum et Ulixen quidam opinantur quando põem diante de suas bocas os escudos, longo illo et fabuloso errore in hunc Oceanum para que a voz se amplifique, mais forte e grave, delatum adisse Germaniae terras, pela reverberação. Voltando ao assunto, alguns Asciburgiumque, quod in ripa Rheni situm crêem que Ulisses, levado a este Oceano naquele hodieque incolitur, ab illo constitutum longo e fabuloso errar, chegou em terras nominatumque; aram quin etiam Ulixi germânicas, e constituiu e deu nome a consecratam, adiecto Laertae patris nomine Ascibúrgio, que está situado às margens do Reno eodem loco olim repertam, monumentaque et e é atualmente habitado. De fato, o altar 
tumulos quosdam ${ }^{3}$ Graecis litteris inscriptos in consagrado a Ulisses, com o acréscimo do nome confinio Germaniae Raetiaeque adhuc extare. de seu pai Laertes, outrora encontrado naquele quae neque confirmare argumentis neque mesmo lugar, bem como monumentos e alguns refellere in animo est: ex ingenio suo quisque túmulos com inscrições em grego ainda existem demat vel addat fidem.

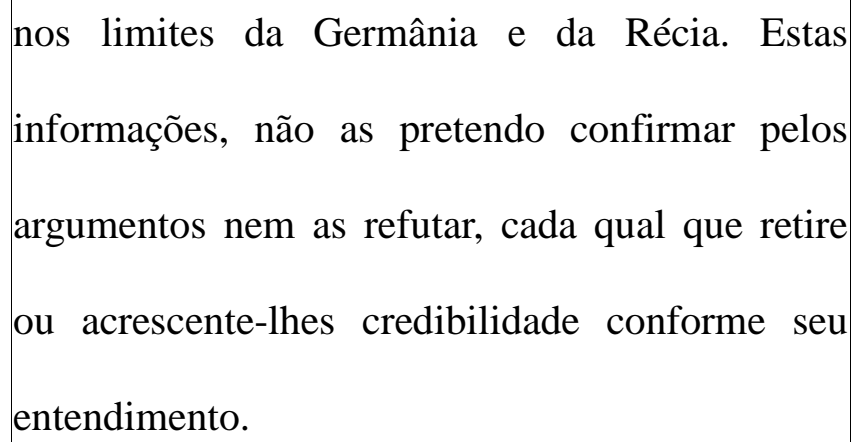
nos limites da Germânia e da Récia. Estas informações, não as pretendo confirmar pelos argumentos nem as refutar, cada qual que retire ou acrescente-lhes credibilidade conforme seu entendimento.

4. Ipse eorum opinionibus accedo, qui 4. Eu próprio concordo com aqueles que julgam Germaniae populos nullis aliis aliarum que os povos da Germânia não se mesclaram, por nationum conubiis infectos propriam et meio do casamento, com outras nações, dada a sinceram et tantum sui similem gentem extitisse peculiaridade, pureza e tamanha similaridade de arbitrantur. unde habitus quoque corporum, sua gente. Até o aspecto de seus corpos, embora tamquam in tanto hominum numero, idem haja um grande número de pessoas, é igual em omnibus: truces et caerulei oculi, rutilae comae, todos: olhos azuis e ameaçadores, cabelos ruivos, magna corpora et tantum ad impetum valida. corpanzis vigorosos somente ao embate; não com laboris atque operum non eadem patientia, a mesma firmeza suportam o trabalho e os minimeque sitim aestumque tolerare, frigora afazeres e muito menos toleram a sede e o calor atque inediam caelo solove assueverunt. intenso, mas graças ao clima e ao terreno habituaram-se ao frio e à fome.

\footnotetext{
3 Pensamos que traduzir esta passagem (e as demais do mesmo tipo) de forma a não reproduzir essa característica da escola retórica a que pertencia Tácito, que consiste na justaposição de dois substantivos ou adjetivos sinônimos, como que para reforçar a idéia ou melhor expressá-la, prejudicaria a versão justamente por privá-la desta propriedade existente no texto latino. A tradução inglesa de Hutton traz: certas sepulturas com túmulos (certain barrows with monuments), não mantendo a construção do texto latino, o que fará posteriormente em 10.3, por exemplo; e a francesa, de Burnouf: monumentos e túmulos (et que des monuments et des tombeaux).
} 
5. Terra etsi aliquanto specie differt, in 5. Ainda que a região difira um pouco em universum tamen aut silvis horrida aut aparência, no geral, contudo, é temível pelas paludibus foeda, humidior qua Gallias, florestas e repugnante por conta dos pântanos, ventosior qua Noricum ac Pannoniam aspicit; chove mais próximo às Gálias e venta mais satis ferax, frugiferarum arborum impatiens, próximo de Nórico e da Panônia; é bastante fértil, pecorum fecunda, sed plerumque improcera. ne mas não dá árvores frutíferas e é abundante em armentis quidem suus honor aut gloria frontis: gado que são, em sua maioria, de pequeno porte. numero gaudent, eaeque solae et gratissimae Sua honra e glória certamente não derivam da opes sunt. argentum et aurum propitiine an irati aparência dos rebanhos: alegram-se com a dii negaverint dubito. nec tamen affirmaverim quantidade, e estas são as únicas e mais nullam Germaniae venam argentum aurumve agradáveis riquezas que possuem. Se foram gignere: quis enim scrutatus est? possessione et deuses favoráveis ou encolerizados que lhes usu haud perinde afficiuntur: est videre apud negaram o ouro e a prata, eu não saberia dizer. E illos argentea vasa legatis et principibus eorum também não afirmaria que nenhuma mina da muneri data non in alia vilitate quam quae humo Germânia produz prata ou ouro: quem a finguntur; quamquam proximi ob usum explorou? Não são afetados pela posse e pelo uso commerciorum aurum et argentum in pretio igualmente. Vê-se entre eles vasilhas de prata, habent formasque quasdam nostrae pecuniae dadas de presente a seus embaixadores e agnoscunt atque eligunt: interiores simplicius et governantes, mas estas são tidas como ninharias antiquius permutatione mercium utuntur. não diversas das que são produzidas pela terra. pecuniam probant veterem et diu notam, Embora os mais próximos à fronteira, pelo hábito serratos bigatosque. argentumque ${ }^{4}$ magis quam do comércio, vendam o ouro e a prata por um aurum sequuntur, nulla affectione animi, sed bom preço e conheçam algumas formas de nossa

\footnotetext{
${ }^{4}$ Adotamos a opção "argentum quoque magis quam aurum sequuntur" para a versão dessa passagem, por reconhê-la mais adequada ao contexto. Esta lição consta no texto estabelecido em TACITUS, 2006.
} 


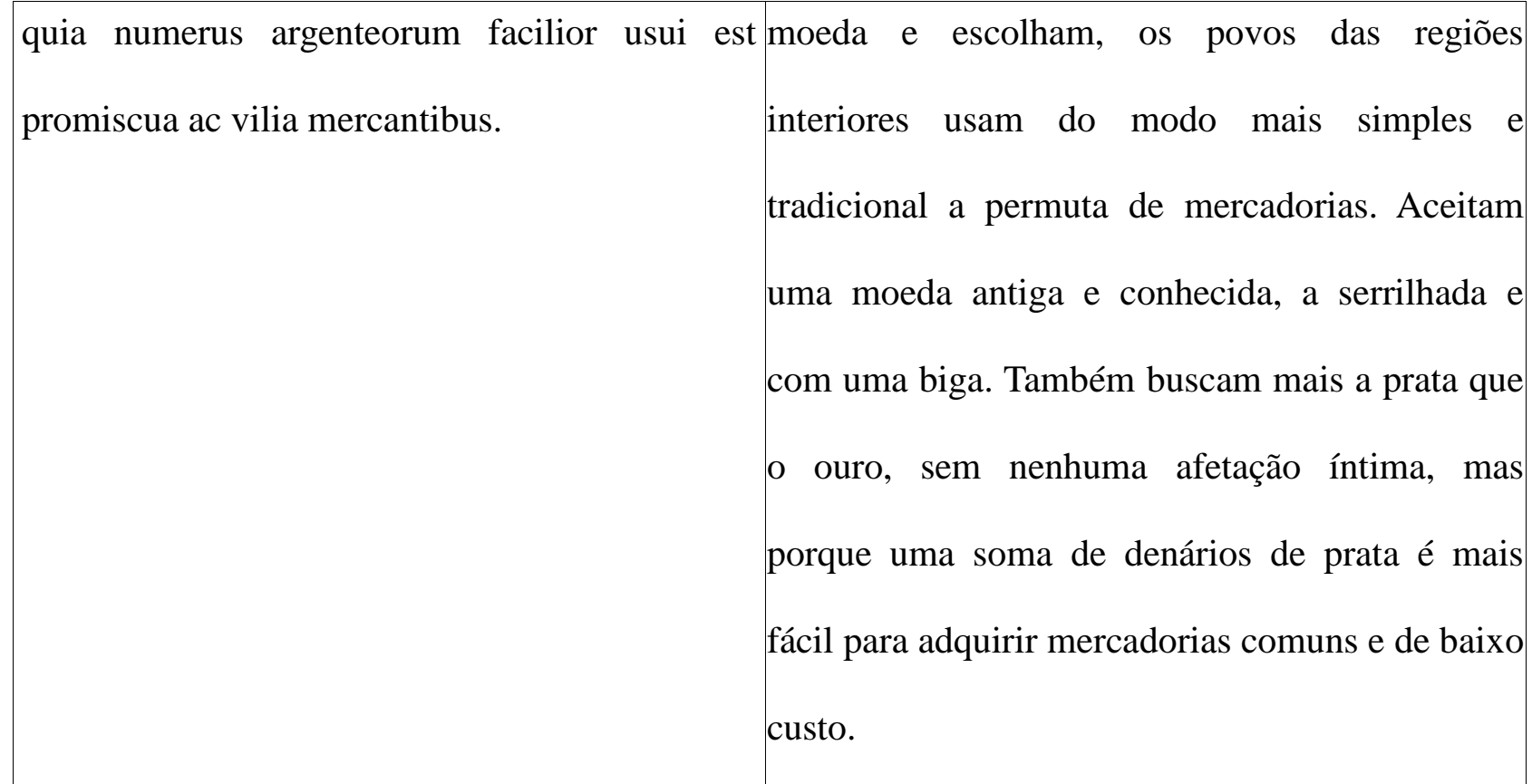

6. Ne ferrum quidem superest, sicut ex genere 6. Na verdade, nem o ferro é abundante, como se telorum colligitur. rari gladiis aut maioribus pode inferir pelo tipo de suas armas. Raros são os lanceis utuntur: hastas vel ipsorum vocabulo que usam espadas ou lanças maiores: produzem frameas $^{5}$ gerunt angusto et brevi ferro, sed ita lanças, ou pela denominação deles próprios acri et ad usum habili, ut eodem telo, prout ratio frameas, com sua parte de ferro estreita e curta, poscit, vel cominus vel eminus pugnent. et de tal sorte afiadas e cômodas ao manejo, que eques quidem scuto frameaque contentus est, com a mesma arma, consoante exige a razão, pedites et missilia spargunt, pluraque singuli, lutam quer de perto quer de longe. Um cavaleiro atque in inmensum vibrant, nudi aut sagulo fica satisfeito com um escudo e uma "framea", a leves. nulla cultus iactatio; scuta tantum infantaria atira armas de arremesso, e cada qual lectissimis coloribus distinguunt. paucis loricae, atira muitas a uma longa distância, pois ficam nus vix uni alterive cassis aut galea. equi non forma, ou com um leve traje de guerra. Não há nenhuma

\footnotetext{
${ }^{5}$ Lança curta, uma espada; estas ou outras denominações para essa arma tipicamente germânica poderiam ter sido usadas, mas por ser framea o nome germânico utilizado por Tácito no texto latino, seguido de sua definição, mantivemos a palavra framea todas as vezes que o objeto designado por esse termo é mencionado e também para destacar este vocábulo, um de apenas três que Tácito apresenta da linguagem dos germanos (a mesma opção de tradução vale para: barditum, parágrafo 3, e glesum, parágrafo 45). A tradução brasileira de Stevenson (1950) traz "frâmea", forma esta presente na última edição do Vocabulário Ortográfico da Língua Portuguesa (VOLP, 2009). Na tradução francesa, de Burnouf, a versão é 'framées' e na inglesa, de Hutton, 'frameae'; e assim ocorre também em 6.2.
} 
non velocitate conspicui. sed nec variare gyros ostentação em seu modo de viver; seus escudos in morem nostrum docentur: in rectum aut uno se diferenciam somente pelas mais formosas flexu dextros agunt, ita coniuncto orbe, ut nemo cores. Poucos usam couraças, dificilmente um posterior sit. in universum aestimanti plus penes ou outro usa elmo ou capacete. Os cavalos não peditem roboris; eoque mixti proeliantur, apta et são notáveis nem pela aparência, nem pela congruente ad equestrem pugnam velocitate velocidade, e não são adestrados a dar voltas para peditum, quos ex omni iuventute delectos ante todos os lados como é hábito nosso: seguem em aciem locant. definitur et numerus: centeni ex linha reta ou com uma curva à direita, de tal singulis pagis sunt, idque ipsum inter suos forma que, fechado o círculo, ninguém fique para vocantur, et quod primo numerus fuit, iam trás. De forma geral, julgam haver mais vigor no nomen et honor est. acies per cuneos soldado-infante e combatem unidos no mesmo componitur. cedere loco, dummodo rursus local, sendo adequada e compatível à da pugna instes, consilii quam formidinis arbitrantur. eqüestre a velocidade da infantaria, que é corpora suorum etiam in dubiis proeliis referunt. escolhida dentre a flor da juventude e posta na scutum reliquisse praecipuum flagitium, nec aut linha de frente. A quantidade também é sacris adesse aut concilium inire ignominioso determinada: de cada aldeia provêm cem, e por fas, multique superstites bellorum infamiam esse mesmo numeral são chamados entre os seus: laqueo finierunt.

o que a princípio era apenas um número passou a ser uma denominação e uma honra. O exército ordena-se em forma de cunha. Consideram que deixar o posto, contanto que sigas no encalço em seguida, seja questão de planejamento e não por medo. Levam os corpos dos seus mesmo em prélios ainda irresolutos. Ter abandonado o escudo é a pior desonra, e não é permitido ao 


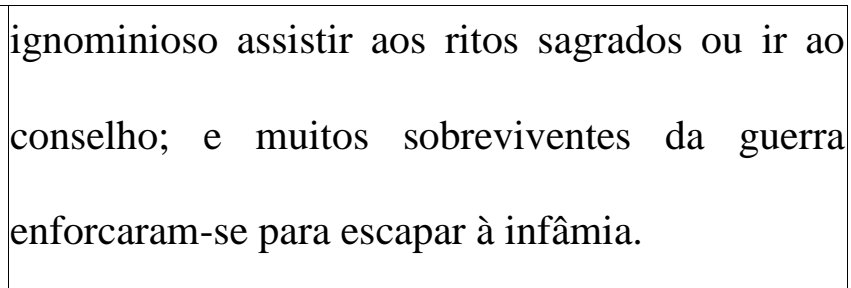

7. Reges ex nobilitate, duces ex virtute sumunt. 7. Eles escolhem seus reis segundo a nobreza e nec regibus infinita aut libera potestas, et duces seus generais segundo a força. O poder para os exemplo potius quam imperio, si prompti, si reis não é ilimitado e irrefreado, os generais antes conspicui, si ante aciem agant, admiratione dão o exemplo que ordens, e são os mais praesunt. ceterum neque animadvertere neque admirados se estão preparados e visíveis na linha vincire, ne verberare quidem nisi sacerdotibus de frente. Ademais, castigar, acorrentar, açoitar, permissum, non quasi in poenam nec ducis somente é permitido aos sacerdotes, não como iussu, sed velut deo imperante, quem adesse uma forma de punição ou por ordem do general, bellantibus credunt. effigiesque et signa mas como uma ordem do deus que crêem estar quaedam detracta lucis in proelium ferunt; junto a eles na batalha. Algumas imagens e quodque praecipuum fortitudinis incitamentum símbolos são retirados dos bosques sagrados e est, non casus nec fortuita conglobatio turmam carregados para o prélio; e isto é o principal aut cuneum facit, sed familiae et propinquitates; estímulo da coragem, pois não foi o acaso nem a et in proximo pignora, unde feminarum ululatus reunião fortuita que compôs a armada e a audiri, unde vagitus infantium. hi cuique formação em cunha, mas as famílias e as sanctissimi testes, hi maximi laudatores: ad amizades; e ainda têm perto de si as pessoas que matres, ad coniuges vulnera ferunt; nec illae lhes são mais caras, em local donde se pode ouvir numerare aut exigere plagas pavent, cibosque et os berros das mulheres e o choro das crianças. hortamina pugnantibus gestant.

Estas são as testemunhas mais sagradas para cada um deles, estas são suas maiores lisonjeadoras: levam suas feridas até suas mães, até suas esposas, as quais não temem contar seus 
ferimentos ou examiná-los, trazendo alimentos e exortações aos guerreiros.

8. Memoriae proditur quasdam acies inclinatas 8. Contam as narrativas que algumas batalhas, já iam et labantes a feminis restitutas constantia a ponto de perder-se, foram restabelecidas pelas precum et obiectu pectorum et monstrata mulheres, dada a constância de suas preces e a cominus captivitate, quam longe impatientius interposição de seus peitos, assim indicado de feminarum suarum nomine timent, adeo ut perto o cativeiro, o que eles temem mais efficacius obligentur animi civitatum ${ }^{6}$, quibus arrebatadoramente com relação a suas mulheres, inter obsides puellae quoque nobiles imperantur. a ponto de serem mais eficazmente constrangidos inesse quin etiam sanctum aliquid et providum os ânimos dos povos a quem se exige, dentre os putant, nec aut consilia earum aspernantur aut reféns, garotas nobres. Ademais disso, julgam responsa neglegunt. vidimus sub divo haver nas mulheres algo de sagrado e previdente Vespasiano Veledam diu apud plerosque e não desprezam seus conselhos nem numinis loco habitam; sed et olim Albrunam $^{7}$ et negligenciam suas predições. Sob o império de compluris alias venerati sunt, non adulatione Vespasiano, vimos Veleda ser considerada como nec tamquam facerent deas.

uma divindade, durante muito tempo, pela
maioria dos homens; e outrora veneraram
também Aurínia e muitas outras, não com vil
lisonja nem como se forjassem deusas.

9. Deorum maxime Mercurium colunt $^{8}$, cui 9. Dentre os deuses, cultuam sobretudo Mercúrio, certis diebus humanis quoque hostiis litare fas a quem crêem ser permitido até, em certos dias,

\footnotetext{
${ }^{6}$ Civitas nesta passagem refere-se à organização social, podendo ser entendida como "Estado", e por esta razão traduzimo-na como "Cidade". Civitas é empregada com esse sentido também em: 10, 5; 12, 8; 13, 16; 14, 7; 15,$7 ; 19,10 ; 25,9 ; 30,2 ; 43,11 ; 37,2 ; 10,14 ; 41,3 ; 44,6$.

${ }^{7}$ Auriniam

${ }^{8}$ Chamamos atenção aqui para a semelhança deste período com De Bello Gallico VI. 17,1, tratando dos gauleses: deum maxime Mercurium colunt. A única diferença é o caso e número da palavra deus, que em César é acusativo singular e em Tácito genitivo plural, mas ainda assim ambas as frases mantêm o mesmo significado.
} 


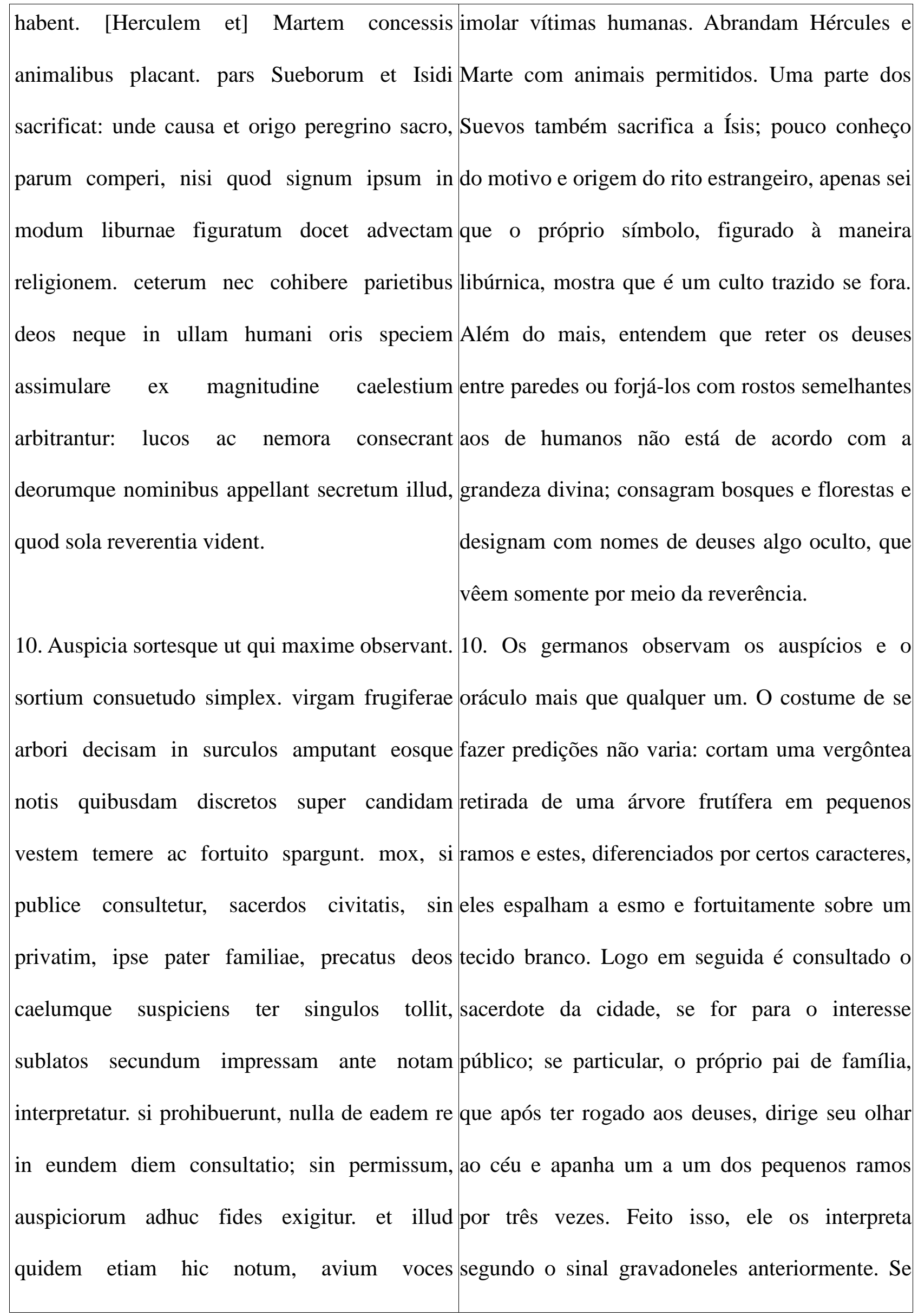


volatusque interrogare: proprium gentis algo for vetado, nenhuma consulta a respeito do equorum quoque praesagia ac monitus experiri. mesmo assunto é feita no mesmo dia, mas se for publice aluntur iisdem nemoribus ac lucis, permitido, uma prova ainda é exigida dos candidi et nullo mortali opere contacti; quos auspícios. Também lhes é algo conhecido buscar pressos sacro curru sacerdos ac rex vel princeps respostas nos sons e no voo das aves é algo civitatis comitantur hinnitusque ac fremitus conhecido por eles, mas é próprio desse povo observant. nec ulli auspicio maior fides, non também consultar presságios e predições solum apud plebem: apud proceres, apud utilizando cavalos. Para o interesse público, sacerdotes; se enim ministros deorum, illos alguns cavalos brancos intocados pelo trabalho conscios putant. est et alia observatio humano são criados naqueles mesmos bosques e auspiciorum, qua gravium bellorum eventus florestas, estes são atrelados ao carro sagrado e o explorant. eius gentis, cum qua bellum est, sacerdote e o rei, ou o líder da Cidade, os captivum quoquo modo interceptum cum electo acompanham e observam seus relinchos e popularim suorum, patriis quemque armis, frêmitos. Nenhum outro auspício inspira maior committunt: victoria huius vel illius pro confiança, não só na plebe, mas também nos praeiudicio accipitur.

chefes e sacerdotes; de fato, estes últimos consideram-se servos dos deuses, e aqueles animais, seus confidentes. Há ainda outro tipo de observação dos auspícios, por meio do qual consultam o desenlace das duras guerras. Põem em combate um prisioneiro apanhado do povo contra o qual se guerreia, com um escolhido dentre os seus, cada qual com as armas de sua pátria: a vitória deste ou daquele é tomada como prognóstico. 
11. De minoribus rebus principes consultant, de 11 . Consultam os líderes quando se trata de maioribus omnes, ita tamen, ut ea quoque, assuntos menores, os maiores são tratados por quorum penes plebem arbitrium est, apud todos; entretanto, é de tal forma que também principes praetractentur. coeunt, nisi quid estes últimos, cuja decisão cabe ao povo, são fortuitum et subitum incidit, certis diebus, cum previamente tratados entre os líderes. Reúnem-se aut inchoatur luna aut impletur; nam agendis em dias determinados: quando a lua começa a rebus hoc auspicatissimum initium credunt. nec crescer ou quando ela se torna cheia, a não ser dierum numerum, ut nos, sed noctium que sobrevenha algo fortuito e súbito; pois crêem computant. sic constituunt, sic condicunt: nox ser este início o mais auspicioso para empreender ducere diem videtur. illud ex libertate vitium, as ações. Não contam, como nós, o número de quod non simul nec ut iussi conveniunt, sed et dias, massim de noites. Assim constituem, assim alter et tertius dies cunctatione coeuntium concordam: a noite parece conduzir ao dia. É um absumitur. ut turbae placuit, considunt armati. vício derivado de sua liberdade não se silentium per sacerdotes, quibus tum et encontrarem ao mesmo tempo, como se coercendi ius est, imperatur. mox rex vel convocados, e assim um dia a mais, e ainda um principes, prout aetas cuique, prout nobilitas, terceiro, é consumido pela delonga dos prout decus bellorum, prout facundia est, participantes. Logo que a multidão tenha audiuntur, auctoritate suadendi magis quam aprovado, sentam-se armados. O silêncio é iubendi potestate. si displicuit sententia, fremitu exigido pelos sacerdotes, os quais detém também aspernantur; sin placuit, frameas concutiunt: o direito de reprimir. Logo depois, o rei ou os honoratissimum assensus genus est armis líderes, de acordo com a idade de cada um, com a laudare.

nobreza, com a glória nas guerras e com a eloquência, são ouvidos mais pelo poder de persuasão que pela capacidade de dar ordens. Se a proposição desagradar, eles a rejeitam com um 
grande alarido, porém, se agradar, agitam as frameas; este louvor com armas é o tipo mais honroso de aprovação.

12. Licet apud concilium accusare quoque et 12. Também é permitido, no Conselho, acusar e discrimen capitis intendere. distinctio poenarum apresentar penas capitais. A distinção entre as ex delicto: proditores et transfugas arboribus penas é estabelecida a partir dos delitos. Os suspendunt, ignavos et imbelles et corpore traidores e desertoressão enforcados, os fracos, infames caeno ac palude, iniecta insuper crate, covardes e pervertidos são mergulhados na lama mergunt. diversitas supplicii illuc respicit, ou num pântano, e uma grade é colocada por tamquam scelera ostendi oporteat, dum cima. A diversidade de suplícios diz respeito à puniuntur, flagitia abscondi. sed et levioribus idéia de que é preciso mostrar os crimes no delictis pro modo poena: equorum pecorumque momento de sua punição e esconder as numero convicti multantur. pars multae regi vel ignomínias. Mas a pena para delitos mais leves é civitati, pars ipsi, qui vindicatur, vel propinquis proporcional: os condenados são multados em eius exsolvitur. eliguntur in iisdem conciliis et uma quantia de cavalos e gado. Uma parte da principes, qui iura per pagos vicosque reddunt; multa é paga ao rei ou à cidade, a outra parte é centeni singulis ex plebe comites consilium par aquele que foi lesado, ou para seus familiares. simul et auctoritas adsunt.

Nestes mesmos Conselhos também são eleitos os líderes, os quais administram a justiça pelos povoados e rincões. Para cada qual há uma centena de acompanhantes populares, que lhes proporcionam conselhos e autoridade.

13. Nihil autem neque publicae neque private 13 . Não tratam de nenhum assunto, público ou 
rei nisi armati agunt. sed arma sumere non ante privado, senão armados. Mas, como é de cuiquam moris, quam civitas ${ }^{9}$ suffecturum costume, ninguém pega em armas antes que os probaverit. tum in ipso concilio vel principum cidadãos reconheçam que haverão de ser capazes aliquis vel pater vel propinqui scuto frameaque e daí então, durante o próprio Conselho, um dos iuvenem ornant: haec apud illos toga, hic líderes ou o pai ou os parentes ornam o jovem primus iuventae honos; ante hoc domus pars com o escudo e a 'framea'; isso, entre eles, é videntur, mox rei publicae. insignis nobilitas aut como a toga, a primeira honra da juventude. magna patrum merita principis dignationem Antes desse momento, ele é considerado membro etiam adulescentulis assignant; ceteri de uma família e, logo em seguida, membro da robustioribus ac iam pridem probatis república. A ilustre nobreza ou os grandes méritos aggregantur, nec rubor inter comites aspici. dos pais dão, mesmo aos adolescentes, o gradus quin etiam ipse comitatus habet, iudicio reconhecimento do príncipe; os demais são eius quem sectantur; magnaque et comitum agregados aos outros mais vigorosos, já há muito aemulatio, quibus primus apud principem suum aprovados, sem que se veja sinal de vergonha locus, et principum, cui plurimi et acerrimi quando junto a seus companheiros. Porém, o comites. haec dignitas, hae vires, magno semper próprio agrupamento apresenta graduações, electorum iuvenum globo circumdari, in pace estabelecidas de acordo com o julgamento decus, in bello praesidium. nec solum in sua daquele que seguem; e então é grande a gente cuique, sed apud finitimas quoque rivalidade entre companheiros na disputa pelo civitates id nomen, ea gloria est, si numero ac primeiro lugar ao lado de seu líder, e também virtute comitatus emineat; expetuntur enim entre os líderes, na disputa pelo agrupamento legationibus et muneribus ornantur et ipsa mais numeroso e mais enérgico. Traz tal $\begin{array}{ll}\text { plerumque fama bella profligant. } & \text { dignidade e poderio estar sempre rodeado por um }\end{array}$

\footnotetext{
${ }^{9}$ Neste caso civitas diz respeito aos próprios cidadãos e por isso foi traduzida por "cidadãos" e não por “Cidade". Ver Gerber e Greef (1962, p. 173).
} 


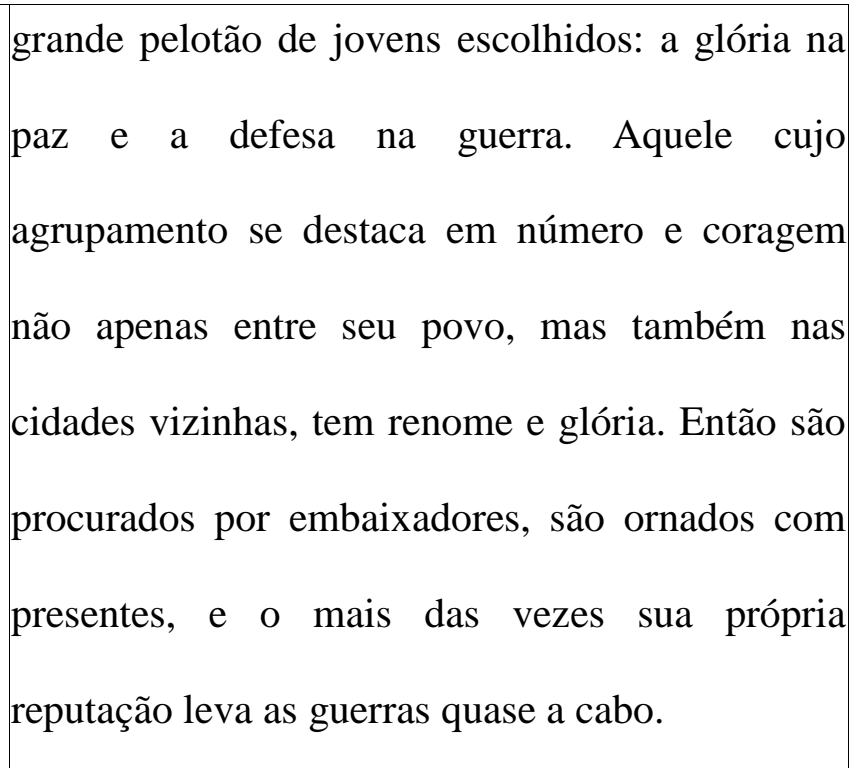

14. Cum ventum in aciem, turpe principi virtute 14. Quando entra na batalha, é vergonhoso para o vinci, turpe comitatui virtutem principis non líder ser vencido em bravura e é vergonhoso para adaequare. iam vero infame in omnem vitam ac os companheiros não se igualar com o líder em probrosum superstitem principi suo ex acie bravura. Além disso, é infame e ignominioso pelo recessisse: illum defendere tueri, sua quoque resto da vida ter abandonado a batalha e fortia facta gloriae eius assignare praecipuum sobrevivido a seu líder; defendê-lo, protegê-lo e sacramentum est: principes pro victoria também atribuir-lhe seus próprios feitos pugnant, comites pro principe. si civitas, in qua grandiosos para a glória dele é a principal orti sunt, longa pace et otio torpeat, plerique consagração militar. Os líderes lutam pela vitória, nobilium adulescentium petunt ultro eas os companheiros pelo líder. Se a Cidade, na qual nationes, quae tum bellum aliquod gerunt, quia nasceram, está entorpecida por uma longa paz e et ingrata genti quies et facilius inter ancipitia pelo ócio, a maioria dos nobres adolescentes clarescunt magnumque comitatum non nisi vi procura por nações que estejam guerreando com belloque tueare; exigunt enim principis sui outras naquele momento, não só porque a inação liberalitate illum bellatorem equum, illam é desagradável para seu povo como também mais cruentam victricemque frameam; nam epulae et facilmente tornam-se ilustres em situações de quamquam incompti, largi tamen apparatus pro perigo e não se mantém um grande agrupamento 
stipendio cedunt. materia munificentiae per sem violência e guerra: é, portanto, da bella et raptus. nec arare terram aut exspectare generosidade de seu líder que reclamam aquele annum tam facile persuaseris quam vocare famoso cavalo de guerra, aquela sanguinária e hostem et vulnera mereri; pigrum quin immo et vitoriosa framea. Com efeito, banquetes e iners videtur sudore acquirere quod possis abundância em apetrechos, ainda que sejam sanguine parare.

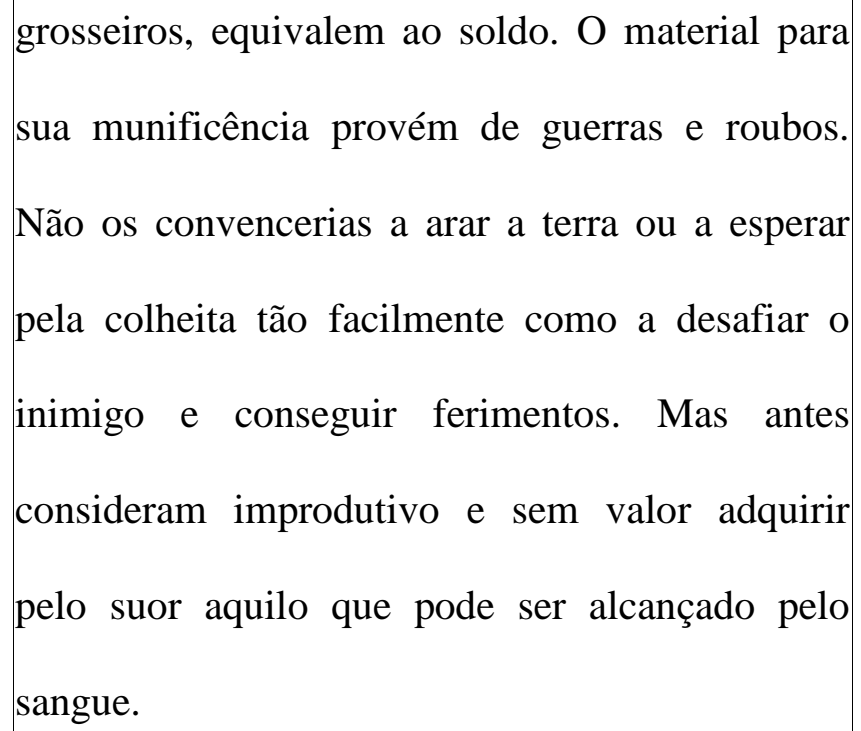
grosseiros, equivalem ao soldo. O material para sua munificência provém de guerras e roubos. Não os convencerias a arar a terra ou a esperar pela colheita tão facilmente como a desafiar o inimigo e conseguir ferimentos. Mas antes consideram improdutivo e sem valor adquirir pelo suor aquilo que pode ser alcançado pelo sangue.

15. Quotiens bella non ineunt, [non] multum 15. Todas as vezes que não vão para a guerra, venatibus, plus per otium transigunt, dediti dedicam-se muito às caçadas, porém vivem mais somno ciboque, fortissimus quisque ac na ociosidade, entregues ao sono e à comida. Os bellicosissimus nihil agens, delegata domus et homens mais fortes e belicosos nada fazendo, o penatium et agrorum cura feminis senibusque et cuidado da casa, dos penates e dos campos infirmissimo cuique ex familia: ipsi hebent, confiado às mulheres, aos velhos e aos mais mira diversitate naturae, cum iidem homines sic incapazes da família; e eles mesmos ficam ament inertiam et oderint quietem. mos est ociosos, devido a uma notável contradição em civitatibus ultro ac viritim conferre principibus sua natureza, que leva os mesmos homens a vel armentorum vel frugum, quod pro honore amarem assim a indolência e a odiarem a inação. acceptum etiam necessitatibus subvenit. gaudent É costume nas cidades servir aos líderes, de modo praecipue finitimarum gentium donis, quae non espontâneo e individualmente, de uma parte de 
modo a singulis, sed et publice mittuntur, electi seu rebanho e de sua seara, o que é aceito como equi, magn<ific>a arma, phalerae torquesque; honra, mas que também cobre suas necessidades. iam et pecuniam accipere docuimus.

Alegram-se, sobretudo, com presentes dos povos vizinhos, que não só são enviados por indivíduos, mas ainda em nome da Cidade: cavalos seletos, magníficas armas, colares e braceletes; e já os ensinamos a aceitar dinheiro.

16. Nullas Germanorum populis urbes habitari 16. Bem se sabe que povos germanos não satis notum est, ne pati quidem inter se iunctas habitam em centros urbanos, na verdade, não sedes. colunt discreti ac diversi, ut fons, ut admitem moradias juntas umas com as outras. campus, ut nemus placuit. vicos locant non in Moram separados e afastados, conforme agrade nostrum morem conexis et cohaerentibus uma fonte, um campo ou um bosque. aedificiis: suam quisque domum spatio Estabelecem povoados não com edificações circumdat, sive adversus casus ignis remedium contíguas e conjugadas, segundo é nosso sive inscientia aedificandi. ne caementorum costume, mas cada qual circunda sua casa com quidem apud illos aut tegularum usus: materia um espaço, como prevenção contra incêndio ou ad omnia utuntur informi et citra speciem aut por falta de habilidade para construir. Nem delectationem. quaedam loca diligentius illinunt mesmo fazem uso de cascalho ou telhas, o terra ita pura ac splendente, ut picturam ac material usado em todas as circunstâncias é liniamenta colorum imitetur. solent et amorfo e sem ornamento ou deleite. subterraneos specus aperire eosque multo Diligentemente revestem certos locais com terra insuper fimo onerant, suffugium hiemi $<\mathrm{s}>$ et tão limpa e esplendente, que simula pintura e receptaculum frugibus, quia rigorem frigorum esboços coloridos. Costumam também abrir eius modi loci molliunt, et si quando hostis cavernas subterrâneas e cobri-las com muito advenit, aperta populatur, abdita autem et esterco, como um refúgio no inverno e despensa 
defossa aut ignorantur aut eo ipso fallunt, quod de grãos, porque locais assim aliviam o rigor do quaerenda sunt.

frio e quando o inimigo chega, destrói aquilo que está à vista, mas os lugares escondidos e debaixo da terra são desconhecidos e ludibriam exatamente porque devem ser procurados.

17. Tegumen omnibus sagum fibula aut, si desit, 17. Todos vestem um saio fechado com uma spina consertum: cetera intecti $^{10}$ totos dies iuxta fivela ou, na falta desta, com um espinho; nus focum atque ignem agunt. locupletissimi veste quanto ao mais, passam dias inteiros junto ao distinguuntur, non fluitante, sicut Sarmatae ac calor do fogo. Os mais ricos são diferenciados Parthi, sed stricta et singulos artus exprimente. pelo uso de uma veste, que não é larga como a gerunt et ferarum pelles, proximi ripae dos Sármatas e dos Partos, mas justa, marcando neglegenter, ulteriores exquisitius, ut quibus todas as formas do corpo. Também trazem em si nullus per commercia cultus. eligunt feras et peles de fera, negligentemente os povos às detracta velamina spargunt maculis pellibusque margens do rio, de modo mais cuidado os que beluarum, quas exterior Oceanus atque ignotum habitam o interior, dado que estes últimos não mare gignit. nec alius feminis quam viris obtêm adornos por relações comerciais.

habitus, nisi quod feminae saepius lineis Primeiro eles escolhem as feras e depois retiram amictibus velantur eosque purpura variant, suas peles e forram-nas com fibras e couro de partemque vestitus superioris in manicas non grandes animais, criados pelo Oceano exterior e extendunt, nudae brachia ac lacertos; sed et desconhecido mar. Este é o traje de homens e proxima pars pectoris patet. mulheres; todavia, as mulheres cobrem-se mais

${ }^{10}$ Este trecho retoma tanto as Metamorfoses de Ovídio, 14, 166 spinis conserto tegmine nullis, quanto a Eneida de Virgílio, 3, 594 consertum tegumen spinis. Ambos tratam de Aquemênidas, quem Odisseu deixa na terra dos Cíclopes. Para THOMAS (2009, p. 59), o porquê de haver esse intertexto aí é difícil dizer, mas acrescenta que também a continuação cetera intecti é claramente moldada na continuação do texto de Virgílio ac cetera Graius. Em Virgílio, Aquemênidas torna-se primitivo por viver na terra dos primitivos Cíclopes, então Tácito, ainda segundo Thomas, estaria sugerindo o primitivismo germânico por esta relação intertextual. Além disso, vemos nesta referência à Eneida de Virgílio o estabelecimento de uma relação com o próprio gênero épico. 


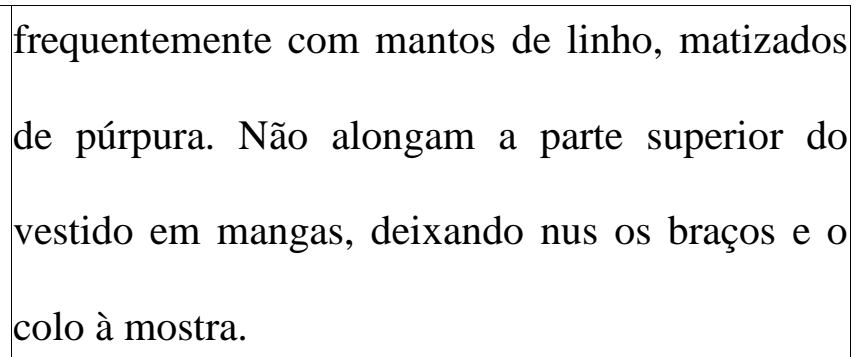

18. Quamquam severa illic matrimonia, nec 18. Embora os casamentos lá sejam austeros, não ullam morum partem magis laudaveris. nam louvarias tanto nenhum outro costume deles. Pois prope soli barbarorum singulis uxoribus eles são praticamente os únicos bárbaros que se contenti sunt, exceptis admodum paucis, qui contentam com uma só esposa, com exceção de non libidine, sed ob nobilitatem plurimis nuptiis alguns poucos que são requisitados a contrair ambiuntur. dotem non uxor marito, sed uxori matrimônios, não por lascívia, mas pela nobreza. maritus offert. intersunt parentes et propinqui ac Não é a esposa que oferece o dote ao marido, e munera probant, munera non ad delicias sim o marido à esposa. Os parentes e amigos muliebres quaesita nec quibus nova nupta estão junto e avaliam os presentes, os quais não comatur, sed boves et frenatum equum et são buscados de acordo com caprichos femininos scutum cum framea gladioque. in haec munera nem se enfeita com estes a recém-casada, são uxor accipitur, atque in vicem ipsa armorum bois, cavalos com rédeas e escudo com 'framea' e aliquid viro affert: hoc maximum vinculum, gládio. Com estes presentes arranja-se uma haec arcana sacra, hos coniugales deos esposa, e ela, por sua vez, leva alguma arma ao arbitrantur. ne se mulier extra virtutum marido: nisto vêem o maior dos vínculos, o cogitationes extraque bellorum casus putet, ipsis mistério sagrado, os deuses conjugais. Para que a incipientis matrimonii auspiciis admonetur esposa não se considere sem pensamentos de venire se laborum periculorumque sociam, idem coragem e sem riscos de guerra, ela é admoestada in pace, idem in proelio passuram ausuramque: a se tornar companheira dos trabalhos e perigos hoc iuncti boves, hoc paratus equus, hoc data desde os auspícios iniciais do matrimônio, e há de arma denuntiant. sic vivendum, sic pereundum: sofrer e arriscar-se igualmente na paz e no prélio; 
accipere se quae liberis inviolata ac digna os bois jungidos, o cavalo aparelhado, as armas reddat, quae nurus accipiant rursusque ad dadas declaram isso. Assim deve viver, assim nepotes referantur.

deve criar: o conhecimento que adquire, inviolado e o conveniente, transmite a seus filhos, e as noras têm de aprender e, em seguida, expor aos netos.

19. Ergo saepta pudicitia agunt, nullis 19. Vivem, portanto, em restrita pudicícia, que spectaculorum illecebris, nullis conviviorum não é corrompida pelos atrativos dos espetáculos irritationibus corruptae. litterarum secreta viri ou pelos excitamentos dos banquetes. Homens e pariter ac feminae ignorant. paucissima in tam mulheres, igualmente, desconhecem a numerosa gente adulteria, quorum poena conversação secreta por meio de cartas. Para uma praesens et maritis permissa: abscisis crinibus população tão numerosa, há pouquíssimos casos nudatam coram propinquis expellit domo de adultério, os quais têm punição imediata e maritus ac per omnem vicum verbere agit; concedida aos maridos: depois de ter seus cabelos publicatae enim pudicitiae nulla venia: non cortados, ela é despida e na frente dos conhecidos forma, non aetate, non opibus maritum o marido a expulsa de casa e a persegue com uma invenerit. nemo enim illic vitia ridet, nec vara por todos os cantos. Não há perdão para a corrumpere et corrumpi saeculum vocatur. pudicícia prostituída ${ }^{15}:$ nem pela beleza, nem pela

${ }^{15}$ J. G. C. Anderson, em seu comentário sobre Germania (Oxford, 1938), expõe que publicatae enim pudicitiae faz referência a mulheres solteiras, como se descobre ao final com maritum invenerit. Até então o assunto era o comportamento durante o matrimônio, portanto, haveria uma brusca mudança no tema. Para Anderson, a continuação do argumento leva a interpretação mais natural e esta é a consideração decisiva. James Fettes (1977) acredita que isso é um erro. Segundo ele, o melhor é inferir o sentido a partir da sentença antecedente, que descreve o método utilizado para castigar a traidora, perseguição per omnem vicum, que seria então tornar público, o que explicaria o uso de publicare e crê resolver o problema com uma mudança no texto, ao invés de enim pudicitiae, impudicitiae. Esta alteração está fundamentada no manuscrito Vat. Lat. 2964, que traz enim inpudititie. E sugere a seguinte tradução para o trecho: "Para impudicícia assim exposta não pode haver perdão; nem beleza, nem juventude, nem riqueza poderiam encontrar-lhe um segundo marido". Entendemos, com Anderson, ser possível a leitura do trecho como se tratando de solteiras; se pensarmos no fio condutor do tema como sendo a impudicícia, não haveria uma ruptura, ademais, a leitura de Fettes pressupõe, necessariamente, a leitura de maritum como alterum maritum, o que não fazemos, pois considerando o trecho posterior: "Certamente, ainda são melhores essas cidades em que apenas as donzelas se casam e vive-se com esperança e voto de esposa uma só vez. Assim, casam-se com um único marido", não 
melius quidem adhuc eae civitates, in quibus idade, nem pelas posses ela encontrará um tantum virgines nubunt et cum spe votoque marido. Lá ninguém ri dos vícios e não dizem uxoris semel transigitur. sic unum accipiunt que corromper ou ser corrompido é próprio da maritum quo modo unum corpus unamque época. Certamente, ainda são melhores essas vitam, ne ulla cogitatio ultra, ne longior cidades em que apenas as donzelas se casam e cupiditas, ne tamquam maritum, sed tamquam vive-se com esperança e voto de esposa uma só matrimonium ament. numerum liberorum finire vez. Assim, casam-se com um único marido, de aut quemquam ex agnatis necare flagitium forma a haver um único corpo e uma única vida e habetur, plusque ibi boni mores valent quam não haja outro pensamento ou paixão posterior e alibi bonae leges.

para que o amem não por ser um marido, mas por
ser um matrimônio. Determinar o número de
filhos ou matar algum dos que nascerem a mais é
considerado ação torpe; e bons costumes ali
valem mais que boas leis em outro lugar.

20. In omni domo nudi ac sordidi in hos artus, 20. Em todas as casas, as crianças crescem nuas e in haec corpora, quae miramur, excrescunt. sua sujas quanto a braços e pernas e quanto aos quemque mater uberibus alit, nec ancillis aut corpos, os quais admiramos. Sua mãe alimenta-as nutricibus delegantur. dominum ac servum com os seios, e não as confia a criadas ou amas. nullis educationis deliciis dignoscas: inter Você não conseguiria discernir o senhor do eadem pecora, in eadem humo degunt, donec escravo por caprichos de criação; eles passam o aetas separet ingenuos, virtus agnoscat. sera tempo em meio aos mesmos animais e no mesmo iuvenum venus, eoque inexhausta pubertas. nec chão, até que a idade distinga os nascidos livres e virgines festinantur; eadem iuventa, similis a virtude os reconheça. A vida sexual dos jovens

há como pensar em um segundo casamento, por qualquer que seja o motivo do término do primeiro. Entretanto, considerando também válido o ponto de vista de Fettes e acreditando ser o próprio período em latim passível de mais de um entendimento, procuramos, na versão, manter essa abertura. 
proceritas: pares validaeque miscentur, ac demora para começar e por isso a mocidade é robora parentum liberi referunt. sororum filiis vigorosa. As moças não se apressam em casar; idem apud avunculum qui apud patrem honor. elas vivem a mesma juventude que eles e têm quidam sanctiorem artioremque hunc nexum estaturas semelhantes. Quando se unem, são sanguinis arbitrantur et in accipiendis obsidibus iguais em idade e força e seus filhos reproduzem magis exigunt, tamquam et animum firmius et em si a robustez dos pais. Com relação aos filhos domum latius teneant. heredes tamen das irmãs, a consideração do tio é a mesma que a successoresque sui cuique liberi, et nullum do pai. Alguns julgam ser esse vínculo sanguíneo testamentum. si liberi non sunt, proximus mais sagrado e estreito e, ao receber prisioneiros, gradus in possessione fratres patrui avunculi. isso é o que mais exigem, como se assim quanto plus propinquorum, quanto maior obtivessem um caráter mais firme e uma família affinium numerus, tanto gratiosior senectus; nec maior. Entretanto, os herdeiros e sucessores de ulla orbitatis pretia.

$$
\begin{aligned}
& \text { cada qual são seus filhos e não há nenhum } \\
& \text { testamento; se não houver filhos, os graus de } \\
& \text { parentesco mais próximos para a posse dos bens } \\
& \text { são irmãos, tios paternos e tios maternos. Quanto } \\
& \text { mais parentes, quanto maior o número de amigos, } \\
& \text { tanto mais favorecida será a velhice; e não se } \\
& \text { paga preço algum pela falta de filhos }
\end{aligned}
$$

21. Suscipere tam inimicitias seu patris seu 21. É necessário adotar as inimizades de seu pai propinqui quam amicitias necesse est; nec ou parente assim como suas amizades; e não inplacabiles durant; luitur enim etiam subsistem os renitentes, pois por um homicídio homicidium certo armentorum ac pecorum paga-se com certa quantia de gado e animais de numero recipitque satisfactionem universa seu rebanho e a família inteira aceita a reparação, domus, utiliter in publicum, quia periculosiores com proveito para todos, porque as inimizades 
\begin{tabular}{|l|l}
\hline sunt inimicitiae iuxta libertatem. & são mais perigosas entre pessoas livres.
\end{tabular}

Convictibus et hospitiis non alia gens effusius Nenhum outro povo concede tão abundantemente indulget. quemcumque mortalium arcere tecto familiaridade e hospitalidade. É considerado nefas habetur; pro fortuna quisque apparatis crime negar abrigo a qualquer ser humano; cada epulis excipit. cum defecere, qui modo hospes um, conforme suas posses, acolhe com um fuerat, monstrator hospitii et comes; proximam magnificente banquete. Depois de terminado, domum non invitati adeunt. nec interest: pari aquele que há pouco era o hóspede, é o que indica humanitate accipiuntur. notum ignotumque quem hospedará e acompanha, então adentram na quantum ad ius hospitis nemo discernit. abeunti, casa vizinha sem terem sido convidados. Mas não si quid poposcerit, concedere moris; et poscendi importa, eles são recebidos com a mesma polidez. in vicem eadem facilitas. gaudent muneribus, Ninguém faz distinção entre conhecidos e sed nec data imputant nec acceptis obligantur. desconhecidos no que diz respeito ao direito de [victus inter hospites communis. $]^{11}$

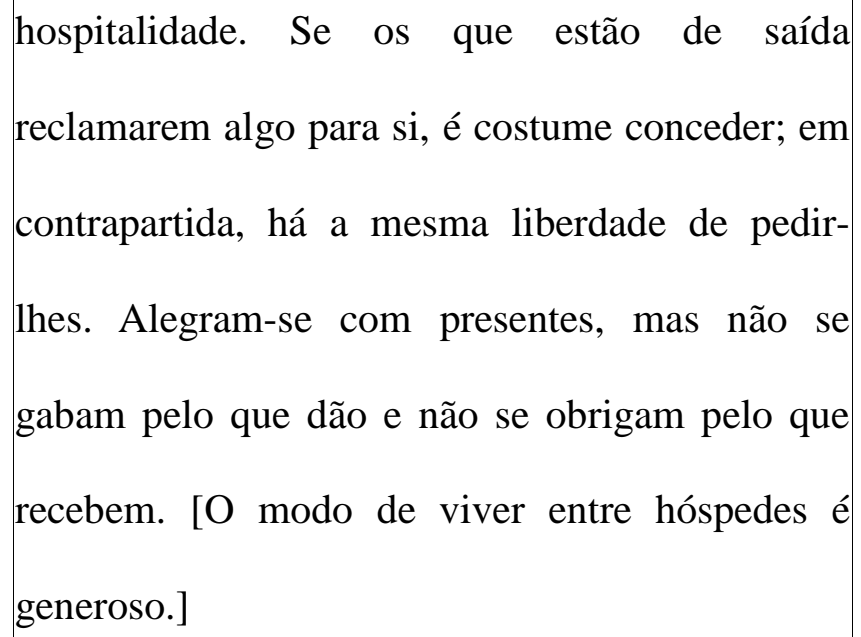
hospitalidade. Se os que estão de saída reclamarem algo para si, é costume conceder; em contrapartida, há a mesma liberdade de pedirlhes. Alegram-se com presentes, mas não se gabam pelo que dão e não se obrigam pelo que recebem. [O modo de viver entre hóspedes é generoso.]

22. Statim e somno, quem plerumque in diem 22. Depois de despertarem do sono, que quase extrahunt, lavantur, saepius calida, ut apud quos sempre prolongam pelo dia, lavam-se geralmente plurimum hiems occupat. lauti cibum capiunt: em água quente, já que entre eles o inverno é

\footnotetext{
${ }^{11}$ Nesta passagem, adotamos para a tradução a versão comis apresentada no lugar de communis nos manuscritos da classe X do arquétipo perdido Hersfeld, a saber: Codex Vaticanus Lat. 1862 B e Codex Leidensis Perizonianus XVIII Q. 21 b. A opção foi feita em razão de sua melhor adequação semântica ao contexto. A tradução da sentença entre colchetes poderia ser: [Entre os hóspedes, o alimento é compartilhado]; de qualquer forma, o trecho está entre colchetes pela incerteza que apresenta quanto à sua fidelidade.
} 
separatae singulis sedes et sua cuique mensa. predominante. Limpos, fazem a refeição em tum ad negotia nec minus saepe ad convivia cadeiras individuais e cada qual em sua mesa. procedunt armati. diem noctemque continuare Então, vão aos negócios, e não raras vezes aos potando nulli probrum. crebrae, ut inter banquetes, armados. Passar o dia e a noite vinolentos, rixae raro conviciis, saepius caede et bebendo não é vergonha para nenhum deles. As vulneribus transiguntur. sed et de reconciliandis duras brigas entre bêbados, raramente com invicem inimicis et iungendis affinitatibus et gritarias, terminam geralmente em derramamento asciscendis principibus, de pace denique ac de sangue e ferimentos. No entanto, quase sempre bello plerumque in conviviis consultant, deliberam nesses banquetes sobre a reconciliação tamquam nullo magis tempore aut ad simplices recíproca de inimigos, a formação de alianças, a cogitationes pateat animus aut ad magnas eleição de chefes e até mesmo a paz e a guerra, incalescat. gens non astuta nec callida aperit como se em nenhum outro momento o espírito adhuc secreta pectoris licentia loci; ergo detecta estivesse mais aberto a simples reflexões ou se et nuda omnium mens. postera die retractatur, et aquecesse mais para as grandes. O povo, que não salva utriusque temporis ratio est: deliberant, é astucioso nem sagaz, expõe os até então dum fingere nesciunt, constituunt, dum errare segredos do coração pela licença da non possunt.

circunstância; portanto, a mente de todos está descoberta e nua. No dia seguinte, a argumentação é retomada, sem prejuízo de um ou outro momento: deliberam quando não conseguem fingir e decidem quando não podem duvidar.

23. Potui humor ex hordeo aut frumento, in 23. Para beber há um líquido feito de cevada e quandam similitudinem vini corruptus; proximi grãos, que depois de fermentado guarda certa ripae et vinum mercantur. cibi simplices, semelhança com o vinho. Os povos próximos às 
agrestia poma, recens fera aut lac concretum: margens do rio também compram vinho. As sine apparatu, sine blandimentis expellunt refeições são simples, frutas do campo, carne famem. adversus sitim non eadem temperantia. fresca, leite coalhado; matam a fome sem si indulseris ebrietati suggerendo quantum refinamento, sem delícias. Com relação à sede, concupiscunt, haud minus facile vitiis quam não usam da mesma moderação. Se fores armis vincentur. complacente com sua embriaguez, trazendo o quanto desejarem, tão mais facilmente serão vencidos pelos vícios como pelas armas.

24. Genus spectaculorum unum atque in omni 24. O tipo de espetáculo é um só e o mesmo em coetu idem: nudi iuvenes, quibus id ludicrum todo encontro: jovens nus, que consideram um est, inter gladios se atque infestas frameas saltu divertimento lançar-se com um salto em meio a iaciunt. exercitatio artem paravit, ars decorem, espadas e hostis 'frameas'. A prática levou à non in quaestum tamen aut mercedem: quamvis habilidade e a habilidade à elegância, mas não audacis lasciviae pretium est voluptas para proveito ou por paga; ainda que sejam spectantium. aleam, quod mirere, sobrii inter brincadeiras audaciosas, a satisfação dos seria exercent, tanta lucrandi perdendive espectadores é sua recompensa. Ocupam-se de temeritate, ut, cum omnia defecerunt, extremo jogos quando sóbrios como de um assunto sério, ac novissimo iactu de libertate ac de corpore o que é de se admirar, com tanto desatino para contendant. victus voluntariam servitutem adit: ganhar ou perder que, quando se esgotarem todas quamvis iuvenior, quamvis robustior alligari se as possibilidades, disputarão seu corpo e ac venire patitur. ea est in re prava pervicacia, liberdade em um lance extremo e derradeiro. $\mathrm{O}$ ipsi fidem vocant. servos condicionis huius per perdedor segue em voluntária servidão e ainda commercia tradunt, ut se quoque pudore que seja o mais jovem e mais forte, ele sofre por victoriae exsolvant. ser preso e vendido; tal a persistência em uma prática insensata, a que eles chamam de 


integridade. Comercializam escravos desta
condição, para que também se liberem da
vergonha de uma vitória assim.

25. Ceterum ${ }^{12}$ servis non in nostrum morem, 25. Possuem escravos, que não são, como é nosso descriptis per familiam ministeriis, utuntur: costume, designados para serviços domésticos. suam quisque sedem, suos penates regit. Cada um governa sua casa e moradia. O senhor frumenti modum dominus aut pecoris aut vestis demanda dele, como de um colono, uma ut colono iniungit, et servus hactenus paret: quantidade de grãos, animais ou vestes, e o cetera domus officia uxor ac liberi exsequuntur. escravo é bastante obediente. A esposa e os filhos verberare servum ac vinculis et opere coercere realizam os demais afazeres do lar. Bater em um rarum: occidere solent, non disciplina et escravo e castigá-lo com trabalho e amarras é severitate, sed impetu et ira, ut inimicum, nisi raro: costumam matá-los, não por disciplina ou quod impune est. liberti non multum supra rigor, mas por impulso e raiva, como a um servos sunt, raro aliquod momentum in domo, inimigo, fora isso não há punição. Os homens numquam in civitate, exceptis dumtaxat iis livres não são muito superiores aos escravos; gentibus quae regnantur. ibi enim et super estes raramente possuem alguma influência na ingenuos et super nobiles ascendunt: apud casa, nunca na Cidade, com exceção apenas ceteros impares libertini libertatis argumentum daqueles povos comandados por reis; lá, com sunt. efeito, eles sobrelevam-se aos homens livres e aos nobres, mas para os outros, as desigualdades entre os libertos são prova de liberdade.

26. Faenus agitare et in usuras extendere 26. É desconhecida a prática da usura e o ignotum; ideoque magis servatur quam si acúmulo de dinheiro por juros, por isso tal atitude

\footnotetext{
${ }^{12} \mathrm{O}$ texto latino estabelecido pela LOEB (TACITUS, 2006) traz ceteris e uma possibilidade de versão seria:
} Possuem outros escravos 
vetitum esset. agri pro numero cultorum ab é mais observada do que se fosse proibida. Os universis in vicem occupantur, quos mox inter campos são, sucessivamente, ocupados por todos se secundum dignationem partiuntur; facilitatem os agricultores, de acordo com a quantidade partiendi camporum spatia praestant. arva per deles, e depois partilhados entre eles conforme a annos mutant, et superest ager. nec enim cum posição social. A extensão dos territórios facilita ubertate et amplitudine soli labore contendunt, a partilha. Mudam de terreno ano a ano e ainda ut pomaria conserant et prata separent et hortos sobra campo a cultivar, pois não desgastam a rigent: sola terrae seges imperatur. unde annum fertilidade e a dimensão do solo pelo cultivo, já quoque ipsum non in totidem digerunt species: que plantam pomares, separam os prados e regam hiems et ver et aestas intellectum ac vocabula os vegetais. Exige-se da terra somente grãos, por habent, autumni perinde nomen ac bona essa razão, não dividem o próprio ano em tantas ignorantur. estações: inverno, primavera e verão têm significação e nomes, do outono ignoram igualmente a denominação e as vantagens.

27. Funerum nulla ambitio: id solum observatur, 27. Não há ostentação nos funerais. Cuidam ut corpora clarorum virorum certis lignis apenas em cremar os corpos dos homens ilustres crementur. struem rogi nec vestibus nec com a madeira adequada. Não alimentam as odoribus cumulant: sua cuique arma, chamas da fogueira funerária com roupas ou quorundam igni et equus adicitur. sepulcrum perfumes; mas para cada um, suas armas, e ainda caespes erigit: monumentorum arduum et o cavalo de alguns é atirado ao fogo. Uma leiva operosum honorem ut gravem defunctis forma o túmulo, pois rejeitam a difícil e aspernantur. lamenta ac lacrimas cito, dolorem trabalhosa homenagem dos monumentos como se et tristitiam tarde ponunt. feminis lugere fosse pesado para os defuntos. Rapidamente honestum est, viris meminisse. deixam de lado as lamentações e as lágrimas, Haec in commune de omnium Germanorum vagarosamente, a dor e a tristeza. Às mulheres é 
origine ac moribus accepimus; nunc singularum decoroso chorar, aos homens, recordar. gentium instituta ritusque, quatenus differant, Soubemos em geral estas coisas a respeito da quae<que> nationes e Germania in Gallias origem e costumes de todos os germanos. Agora commigraverint, expediam. apresentarei os ritos e as convenções de cada povo, até que ponto diferem entre si, e quais nações migraram da Germânia para as Gálias.

28. Validiores olim Gallorum res fuisse summus 28. O divino Júlio, o melhor dentre os escritores, auctorum Divus Iulius tradit; eoque credibile est relata que a posição dos gauleses, outrora era etiam Gallos in Germaniam transgressos. mais forte e certamente por isso é crível terem os quantulum enim amnis obstabat quominus, ut gauleses passado para a Germânia ${ }^{16}$. E quanto um quaeque gens evaluerat, occuparet rio opunha-se a que cada povo que se fortalecera permutaretque sedes promiscuas adhuc et nulla ocupasse e trocasse de sítio, até então públicos e regnorum potentia divisas? igitur inter não divididos pelo poder dos reinos? Assim Hercyniam silvam Rhenumque et Moenum sendo, os helvécios habitaram a região entre a amnes Helvetii, ulteriora Boii, Gallica utraque floresta Hercínia e os rios Reno e Meno, as terras gens, tenuere. manet adhuc Boihaemi nomen para além as ocuparam os Boios, um e outro significatque loci veterem memoriam quamvis povos gauleses. O nome Boiemos permanece até mutatis cultoribus. sed utrum Aravisci in hoje e atesta a antiga tradição do local embora Pannoniam ab Osis, Germanorum natione, an tenham mudado seus moradores.

Osi ab Araviscis in Germaniam commigraverint, Mas se foram os araviscos que, provindos dos cum eodem adhuc sermone institutis moribus osos [nação de germanos], migraram para a utantur, incertum est, quia pari olim inopia ac Panônia ou se foram os osos que, provindos dos libertate eadem utriusque ripae bona malaque araviscos, migraram para a Germânia, não se sabe

16 Ac fuit tempus, cum Germanos Galli virtute superarent, ultro bella inferrent, propter hominum multitudinem agrique inopiam trans Rhenum colonias mitterent. Comentarii De Bello Gallico, VI, 24.

Tácito não só conhecia os Comentarii, como lera o sexto livro, no qual há uma digressão sobre os germanos. 
erant. Treveri et Nervii circa affectationem ao certo, já que até hoje utilizam o mesmo idioma Germanicae originis ultro ambitiosi sunt, e os mesmos princípios e costumes; porque tamquam per hanc gloriam sanguinis a outrora se igualavam em pobreza e liberdade e similitudine et inertia Gallorum separentur. havia as mesmas coisas boas e más em ambas as ipsam Rheni ripam haud dubie Germanorum margens do rio. Os trévoros e os nérvios são os populi colunt, Vangiones Triboci Nemetes. ne primeiros a pretenderem com fervor a origem Ubii quidem, quamquam Romana colonia esse germânica, como se por esta relação sanguínea meruerint ac libentius Agrippinenses conditoris gloriosa eles se apartassem da semelhança e sui nomine vocentur, origine erubescunt, inação dos gauleses. Sem dúvida, povos transgressi olim et experimento fidei super germânicos habitam a margem do Reno: ipsam Rheni ripam collocati, ut arcerent, non ut vangíones, tribocos e nêmetes. Nem mesmo os custodirentur.

$$
\begin{aligned}
& \text { úbios, ainda que tenham merecido ser colônia } \\
& \text { romana e por vontade própria sejam chamados } \\
& \text { 'agripinenses' devido ao nome de seu fundador, } \\
& \text { envergonham-se de sua origem; há muito tempo, } \\
& \text { atravessam o Reno e, após provarem sua } \\
& \text { fidelidade, foram estabelecidos sobre a margem } \\
& \text { desse rio, não para serem observados, mas para } \\
& \text { que impedissem a passagem. }
\end{aligned}
$$

29. Omnium harum gentium virtute praecipui 29. De todos estes povos, os mais corajosos são Batavi non multum ex ripa, sed insulam Rheni os batavos, que não ocupam grande extensão da amnis colunt, Chattorum quondam populus et margem, mas habitam uma ilha do rio Reno. seditione domestica in eas sedes transgressus, in Antigamente, eram uma população dos catos e quibus pars Romani imperii fierent. manet por causa de uma guerra civil passaram a esses honos et antiquae societatis insigne; nam nec sítios, onde se tornariam parte do Império 
tributis contemnuntur nec publicanus atterit; Romano. Permanecem a honra e a insígnia da exempti oneribus et collationibus et tantum in antiga aliança, então eles não são rebaixados com usum proeliorum sepositi, velut tela atque arma, tributos nem são oprimidos pelo cobrador de bellis reservantur. est in eodem obsequio et impostos; são isentos de encargos ou Mattiacorum gens; protulit enim magnitudo contribuições e poupados para o uso em batalhas populi Romani ultra Rhenum ultraque veteres somente: do mesmo modo que armas e terminos imperii reverentiam. ita sede armamento são reservados às guerras. $\mathrm{O}$ povo finibusque in sua ripa, mente animoque matíaco desfruta do mesmo benefício, pois a nobiscum agunt, cetera similes Batavis, nisi grandeza da população romana propagou a quod ipso adhuc terrae suae solo et caelo acrius reverência ao império para além do Reno e para animantur. além das vetustas fronteiras. Assim, em sua

Non numeraverim inter Germaniae populos, própria margem está seu assentamento e quamquam trans Rhenum Danuviumque território, mas estão conosco em mente e espírito; consederint, eos qui decumates agros exercent: no mais são similares aos batavos, sem contar que levissimus quisque Gallorum et inopia audax em sua terra recebem maior disposição do solo e dubiae possessionis solum occupavere; mox do clima.

limite acto promotisque praesidiis sinus imperii Não enumerarei dentre as populações da et pars provinciae habentur.

Germânia, embora tenham se assentado além do Reno e do Danúbio, aqueles que cultivam campos decimados. Os mais ágeis gauleses, levados pela temerária pobreza, ocuparam o solo cuja propriedade era incerta; logo depois, com os limites traçados e os postos de defesa movidos adiante, estas terras foram consideradas a extremidade do Império e parte de uma província. 
30. Ultra hos Chatti initium sedis ab Hercynio 30. Para além destes povos, os catos começam saltu incohant, non ita effusis ac palustribus seu assentamento a partir da floresta Hercínia e o locis, ut ceterae civitates, in quas Germania local não é tão amplo ou pantanoso como as patescit, durant siquidem colles, paulatim outras Cidades que compõem a Germânia. Se, rarescunt, et Chattos suos saltus Hercynius contudo, as colinas se estendem, paulatinamente prosequitur simul atque deponit. duriora genti se rarefazem, e a floresta Hercínia acompanha corpora, stricti artus, minax vultus et maior seus catos e os deixa apenas ao final de seu animi vigor. multum, ut inter Germanos, rationis assentamento. Esta gente possui corpos mais ac sollertiae: praeponere electos, audire robustos, membros trabalhados, feição praepositos, nosse ordines, intellegere ameaçadora e maior vigor de espírito. Eles têm occasiones, differre impetus, disponere diem, grande raciocínio e sagacidade, que os destaca vallare noctem, fortunam inter dubia, virtutem dentre os germanos: elegem homens excelentes, inter certa numerare, quodque rarissimum nec ouvem os eleitos, sabem sua posição hierárquica, nisi Romanae disciplinae concessum, plus reconhecem as oportunidades, retardam o ataque, reponere in duce quam in exercitu. omne robur organizam-se durante o dia, entrincheiram-se à in pedite, quem super arma ferramentis quoque noite, incluem a sorte dentre as coisas incertas e a et copiis onerant: alios ad proelium ire videas, coragem dentre as coisas certas e - algo raríssimo Chattos ad bellum. rari excursus et fortuita e somente concedido à disciplina romana pugna. equestrium sane virium id proprium, cito confiam mais no comandante que no exército. parare victoriam, cito cedere: velocitas iuxta Todo poder militar está na infantaria, que além de formidinem, cunctatio propior constantiae est. armas, carrega também utensílios de ferro e provisões: os outros povos, vês irem para a batalha, os catos vão para a guerra. A incursão e a luta casual são raras. De certo, é próprio da força eqüestre alcançar rapidamente a vitória e 
rapidamente retirar-se: a celeridade está muito próxima ao medo, já a demora é ligada à firmeza.

31. Et aliis Germanorum populis usurpatum raro 31. A prática empregada poucas vezes por outras et privata cuiusque audentia apud Chattos in populações dos germanos, e pela ousadia consensum vertit, ut primum adoleverint, individual, tornou-se um consenso entre os catos: crinem barbamque submittere nec nisi hoste deixar o cabelo e a barba crescerem logo que se caeso exuere votivum obligatumque virtuti oris tornassem rapazes e não tirar a vestimenta do habitum. super sanguinem et spolia revelant rosto, devotada e prometida à coragem, até que frontem seque tum demum pretia nascendi tivessem matado o inimigo. Sobre sangue e rettulisse dignosque patria ac parentibus ferunt: espólios revelam sua face, só então eles mostram ignavis et imbellibus manet squalor. fortissimus que mereceram ter nascido e que são dignos da quisque ferreum insuper anulum (ignominiosum pátria e de seus familiares: junto aos pusilânimes id genti) velut vinculum gestat, donec se caede e covardes permanece a miséria. Além disso, os hostis absolvat. plurimis Chattorum hic placet mais valentes usam um anel de ferro (o que é habitus, iamque canent insignes et hostibus ignominioso para este povo) como se fosse um simul suisque monstrati. omnium penes hos grilhão, até o momento em que a morte de um initia pugnarum; haec prima semper acies, visu inimigo o liberta. Este aspecto agrada à maioria nova; nam ne in pace quidem vultu mitiore dos catos, e mesmo com os cabelos mansuescunt. nulli domus aut ager aut aliqua embranquecendo ainda portam as insígnias que cura: prout ad quemque venere, aluntur, prodigi os revela tanto aos inimigos quanto aos amigos. É alieni, contemptores sui, donec exsanguis com estes homens que toda batalha tem início: senectus tam durae virtuti impares faciat.

são sempre a linha de frente do exército, imagem surpreendente. Pois nem na paz se abrandam com um semblante mais tranquilo. Não possuem casa, campo ou outra preocupação; em cada lugar que 


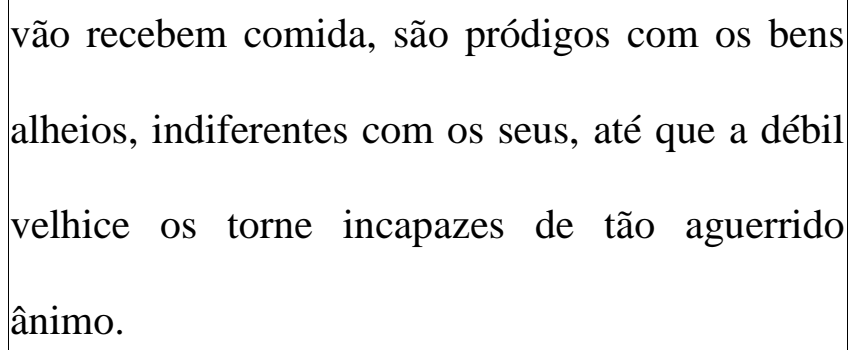

32. Proximi Chattis certum iam álveo Rhenum, 32. Os usípios e os tencteros habitam próximo quique terminus esse sufficiat, Usipi ac Tencteri aos catos, às margens do Reno, cujo leito seguro colunt. Tencteri super solitum bellorum decus já basta como fronteira. Os tencteros, mais do que equestris disciplinae arte praecellunt; nec maior é ordinariamente ilustre nas guerras, são apud Chattos peditum laus quam Tencteris excelentes na arte da disciplina eqüestre. $\mathrm{O}$ equitum sic instituere maiores: posteri imitantur. mérito da infantaria dos catos não é maior que o hi lusus infantium, haec iuvenum aemulati: da cavalaria dos tencteros. Desta forma perseverent senes. inter familiam et penates et instituíram os antigos, seus descendentes os iura successionum equi traduntur: excipit filius, imitam. Estas são as brincadeiras das crianças, a non ut cetera, maximus natu, sed prout ferox emulação dos jovens, e os idosos continuam a bello et melhor.

$$
\begin{aligned}
& \text { fazê-lo. Os cavalos são legados aos escravos, à } \\
& \text { família e aos herdeiros por direito; } \\
& \text { diferentemente de outras coisas, essa herança } \\
& \text { quem a recebe não é o filho mais velho e sim } \\
& \text { aquele que for mais apto e intrépido na guerra. }
\end{aligned}
$$

33. Iuxta Tencteros Bructeri olim occurrebant: 33. Os brúteros outrora vieram para perto dos nunc Chamavos et Angrivarios immigrasse tencteros. Conta-se que os camavos e os narratur, pulsis Bructeris ac penitus excisis angrivários imigraram há pouco, após os brúteros vicinarum consensu nationum, seu superbiae terem sido completamente arruinados e expulsos odio seu praedae dulcedine seu favore quodam por uma união entre as nações vizinhas, seja pela erga nos deorum; nam ne spectaculo quidem aversão a sua soberba, seja pelo atrativo dos 
proelii invidere. super sexaginta milia non armis despojos, seja por um certo favorecimento dos telisque Romanis, sed quod magnificentius est, deuses para conosco, porque certamente não oblectationi oculisque ceciderunt. maneat, invejam a visão da batalha. Mais de sessenta mil quaeso, duretque gentibus, si non amor nostri, at morreram, não por armas ou lanças romanas mas certe odium sui, quando urgentibus imperii fatis para o deleite de nossos olhos, o que é nihil iam praestare fortuna maius potest quam magnífico. Eu rogo que esta situação permaneça hostium discordiam.

e se prolongue entre os povos, se não por amizade a nós, seguramente por ódio a eles; quando os destinos do Império o ameaçam, a Fortuna já não pode oferecer nada melhor que a discórdia entre os inimigos.

34. Angrivarios et Chamavos a tergo Dulgubnii 34. Os angrivários e os camavos são cercados et Chasuarii cludunt aliaeque gentes haud pelos dulgúbnios, pelos casuários e por outros perinde memoratae, a fronte Frisii excipiunt. povos não tão célebres ao sul e são sucedidos maioribus minoribusque Frisiis vocabulum est pelos frísios ao norte. Os frísios são chamados ex modo virium. Utraeque nationes usque ad maiores ou menores à proporção de suas forças. Oceanum Rheno praetexuntur ambiuntque Estes dois povos têm o Reno por limite até o immensos insuper lacus et Romanis classibus oceano e ainda cercam os imensos lagos antes navigatos. ipsum quin etiam Oceanum illa navegados por naus romanas. Foi por ali que temptavimus; et superesse adhuc Herculis tentamos chegar ao oceano. Espalhou-se o boato columnas fama vulgavit, sive adiit Hercules, seu de que até hoje existem colunas de Hércules lá, quidquid ubique magnificum est, in claritatem seja porque Hércules visitou o local, seja porque eius referre consensimus. nec defuit audentia concordamos em atribuir à sua celebridade tudo Druso Germanico, sed obstitit Oceanus in se aquilo que encontramos de magnífico em simul atque in Herculem inquiri. mox nemo qualquer lugar. Não que tenha faltado ousadia a 
temptavit, sanctiusque ac reverentius visum de Druso Germânico, mas o Oceano impediu que actis deorum credere quam scire.

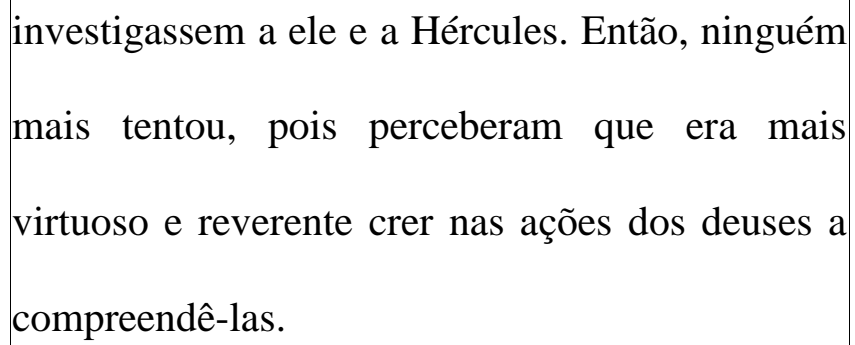
investigassem a ele e a Hércules. Então, ninguém mais tentou, pois perceberam que era mais virtuoso e reverente crer nas ações dos deuses a compreendê-las.

35. Hactenus in occidentem Germaniam 35. Até este ponto nós tomamos conhecimento do novimus; in septentrionem ingenti flexu recedit. ocidente da Germânia; mas esta se volta ao norte ac primo statim Chaucorum gens, quamquam com uma grande inflexão. E logo em primeiro incipiat a Frisiis ac partem litoris occupet, lugar encontramos os caucos, que embora omnium quas exposui gentium lateribus principiem após os frísios e ocupem uma parte do obtenditur, donec in Chattos usque sinuetur. tam litoral, estendem-se pela lateral de todos os povos immensum terrarum spatium non tenent tantum dos quais tratei até que fazem uma curva em Chauci, sed et implent, populus inter Germanos direção aos catos. Os caucos não apenas são nobilissimus, quique magnitudinem suam malit proprietários de um vasto território, mas também iustitia tueri. sine cupididate, sine impotentia, o povoam. Eles são a mais nobre população quieti secretique nulla provocant bella, nullis dentre os germanos, que prefere manter sua raptibus aut latrociniis populantur. id grandeza pela justiça. Não são cobiçosos nem praecipuum virtutis ac virium argumentum est, soberbos; tranqüilos e afastados, não provocam quod, ut superiores agant, non per iniurias guerras, não causam devastação com raptos ou adsequuntur; prompta tamen omnibus arma ac, latrocínios. A principal prova de sua coragem e si res poscat, exercitus, plurimum virorum força é que não obtém por meio de injustiças o equorumque; et quiescentibus eadem fama. título de superiores. Há armas preparadas para todos e inclusive, se a situação exigir, um exército muitíssimo numeroso em homens e cavalos; e eles conservam a mesma fama mesmo 
vivendo em paz.

36. In latere Chaucorum Chattorumque 36. Ao flanco dos caucos e dos catos há os Cherusci nimiam ac marcentem diu pacem queruscos, que por muito tempo não foram inlacessiti nutrierunt: idque iucundius quam atacados e desenvolveram uma paz ociosa e tutius fuit, quia inter inpotentes et validos falso desmedida. E isto foi mais por deleite que por quiescas: ubi manu agitur, modestia ac probitas segurança, pois em meio a povos violentos e nomina $^{13}$ superioris sunt. ita qui olim boni fortes, perderás tempo descansando. Onde se vive aequique Cherusci, nunc inertes ac stulti pelo poder, moderação e probidade compõem a vocantur: Chattis victoribus fortuna in reputação do mais poderoso. Assim, os sapientiam cessit. Tracti ruina Cheruscorum et queruscos, que outrora eram chamados de bons e Fosi, contermina gens, adversarum rerum ex justos, agora são os tolos e fracos: para os aequo socii sunt, cum in secundis minores vitoriosos catos a sorte contou por sabedoria. Os fuissent.

fosos, povo vizinho, foram arrastados pela destruição dos queruscos, com eles agora dividem igualmente as adversidades, ainda que tenham sido inferiores em épocas ditosas.

37. Eundem Germaniae sinum proximi Oceano 37. Os cimbros habitam o mesmo golfo da Cimbri tenent, parva nunc civitas, sed gloria Germânia, próximo ao Oceano; a Cidade é

${ }^{13}$ Nos textos latinos de Germania que lemos, a opção é por nomina (Puteolanus), mas o aparato crítico traz também a leitura nomine. Lee (1968) elenca três possibilidades de interpretação para essa versão menos comum, todas muito pouco prováveis dentro do contexto em que se insere, porém, segundo ele, "em Tácito é arriscado negligenciar a leitura mais difícil". A primeira diz que essas qualidades existem apenas com referência ao mais forte; a segunda seria a tradução de nomine por "em nome de", propondo que só o mais forte decide o que é moderado e justo; e a terceira propõe que "moderação e justiça (da parte do mais fraco) é atribuída ao mais forte". Lee ainda apresenta três interpretações para o período com nomina: o mais forte arroga a si mesmo os títulos de moderação e justiça, moderação e justiça são concedidas ao mais forte e moderação e justiça são chamadas por esses nomes somente quando acompanhadas de força superior, de outra forma passariam por covardia e tolice. Esta última opinião sobre o significado dessa passagem, Lee adotou de J. H. Sleeman (Cambridge, 1914) e crê ser esta a mais adequada. Concordamos com Lee quanto a esta última interpretação, pois seguindo o raciocínio que vinha sendo desenvolvido e acompanhando o que se seguirá, "onde se vive pelo poder" as honras da moderação e justiça deixam de ser honras quando praticadas pelos fracos, da mesma forma que a sorte dos vencedores catos tornou-se sabedoria. 
ingens. veterisque famae lata vestigia manent, pequena agora, mas de grande glória. Ainda utraque ripa castra ac spatia, quorum ambitu permanecem amplos vestígios da antiga fama: nunc quoque metiaris molem manusque gentis espaçosos acampamentos em ambas margens do et tam magni exitus fidem. sescentesimum et rio, cujo perímetro dá hoje a você a medida da quadragesimum annum urbs $^{14}$ nostra agebat, multidão e força deste povo e convencem de tão cum primum Cimbrorum audita sunt arma grande êxito. Nossa cidade contava seiscentos e Caecilio Metello et Papirio Carbone consulibus. quarenta anos quando pela primeira vez ouviu-se ex quo si ad alterum imperatoris Traiani falar do exército cimbro, sob o consulado de consulatum computemus, ducenti ferme et Cecílio Metelo e Papírio Carbão. Se calcularmos decem anni colliguntur: tam diu Germania a partir daí até o segundo consulado do imperador vincitur. Medio tam longi aevi spatio multa in Trajano, reuniremos cerca de duzentos e dez vicem damna. non Samnis, non Poeni, non anos: tanto tempo para vencer a Germânia. Hispaniae Galliaeve, ne Parthi quidem saepius Durante tão longo espaço de tempo muitos foram admonuere: quippe regno Arsacis acrior est os prejuízos a ambas as partes. Nem os samnitas, Germanorum libertas. quid enim aliud nobis nem os cartagineses, nem os hispanos, nem os quam caedem Crassi, amisso et ipse Pacor, infra gauleses, nem os partos nos deram mais lições, Ventidium deiectus Oriens obiecerit? at pois que a liberdade dos germanos mostrou-se Germani Carbone et Cassio et Scauro Aurelio et mais dura que a tirania de Arsace. Além da morte Servilio Caepione Maximoque Mallio fusis vel de Crasso, o que mais nos apresentaria o oriente, captis quinque simul consulares exercitus depois de este mesmo ter perdido Pácoro e ter populo Romano, Varum trisque cum eo legiones sido subjugado por Ventídio? Já os germanos, etiam Caesari abstulerunt; nec impune C. tendo derrubado ou aprisionado Carbão, Cássio, Marius in Italia, divus Iulius in Gallia, Drusus Aurélio Escauro, Servílio Cepião e Máximo ac Nero et Germanicus in suis eos sedibus Málio, tiraram cinco exércitos consulares do povo

\footnotetext{
${ }^{14}$ urbs é uma palavra utilizada em Germania apenas para designar a cidade de Roma.
} 
perculerunt: mox ingentes Gai Caesaris minae romano de uma só vez e destruíram ainda Varo e in ludibrium versae. inde otium, donec com ele três legiões de César. Não foi occasione discordiae nostrae et civilium impunemente que C. Mário os derrotou na Itália, armorum expugnatis legionum hibernis etiam o divino Júlio nas Gálias e Druso, Nero e Gallias adfectavere; ac rursus inde pulsi Germânico em sua própria casa. A grande ameaça proximis temporibus triumphati magis quam de Caio César logo se transformou em zombaria. victi sunt.

$$
\begin{aligned}
& \text { Desde então houve paz, até que por ocasião de } \\
& \text { nossa discórdia e dos confrontos civis tomaram } \\
& \text { de assalto os quartéis de inverno das legiões e } \\
& \text { buscaram apoderar-se das Gálias; mas em seguida } \\
& \text { foram expulsos dali e nos últimos tempos tivemos } \\
& \text { mais triunfos que vitórias sobre eles. }
\end{aligned}
$$

38. Nunc de Suebis dicendum est, quorum non 38. Agora se deve tratar dos suevos, que não una, ut Chattorum Tencterorumve gens; compõem um povo uno como os catos ou os maiorem enim Germaniae partem obtinent, tencteros. Com efeito, eles ocupam a maior parte propiis adhuc nationibus nominibusque discreti, da Germânia, mas ainda são separados em nações quamquam in commune Suebi vocentur. insigne com nomes próprios, embora geralmente os gentis obliquare crinem nodoque substringere: chamem de suevos. É característica deste povo sic Suebi a ceteris Germanis, sic Sueborum por os cabelos para o lado e amarrá-los com um ingenui a servis separantur. In aliis gentibus seu nó; desta forma distinguem-se os suevos dos cognatione aliqua Sueborum seu, quod saepe demais germanos e os suevos livres dos escravos. accidit, imitatione, rarum et intra iuventae Em outros povos, quer por haver alguma relação spatium; apud Suebos usque ad canitiem com os suevos quer por imitação (o que sói horrentes capilli retorquentur, ac saepe in ipso ocorrer), esse costume é raro e próprio da vertice religantur; principes et ornatiorem juventude. Entre os suevos, até na velhice os 
habent. ea cura formae, sed innoxia; neque enim cabelos eriçados são colocados para trás e com ut ament amenturve, in altitudinem quandam et frequiência presos na própria cabeça. Os líderes terrorem adituri bella comptius hostium oculis trazem mais ornatos. Estes são os cuidados com a ornantur. aparência, todavia inocentes. O motivo não é para que amem ou sejam amados, mas para, adornadamente, prover àqueles que vão à guerra de uma imagem de certa estatura e aterrorizante aos olhos do inimigo.

39. Vetustissimos nobilissimosque Sueborum 39. Os semnones dizem ser a nação mais antiga e Semnones memorant; fides antiquitatis religione nobre dos suevos; a certeza da antiguidade é firmatur. stato tempore in silvam auguriis assegurada pela religião. Em data marcada, "em patrum et prisca formidine sacram omnes uma floresta sagrada pelas previsões dos <eiusdem> nominis eiusdemque sanguinis antepassados e prisco terror", reúnem-se todas as populi legationibus coëunt caesoque publice populações de mesmo nome e sangue por meio homine celebrant barbari ritus horrenda de seus embaixadores e, depois de matarem um primordia. est et alia luco reverentia: nemo nisi homem publicamente, celebram as horrendas vinculo ligatus ingreditur, ut minor et origens do bárbaro ritual. E há outra reverência potestatem numinis prae se ferens. si forte ao bosque sagrado: ninguém ali adentra a não ser prolapsus est, attolli et insurgere haud licitum: que atado por um liame, mostrando-se inferior per humum evolvuntur. eoque omnis superstitio ante ao poder da divindade. Se por acaso caírem, respicit, tamquam inde initia gentis, ibi regnator não é permitido que sejam erguidos ou se ponham omnium deus, cetera subiecta atque parentia. de pé, devem sair rastejando. Toda a superstição adicit auctoritatem fortuna Semnonum: centum volta-se para o seguinte: como foi lá que se pagis habitant, magnoque corpore efficitur ut se originou o povo, é lá que está o deus soberano de Sueborum caput credant. todas as coisas; os demais devem ser 


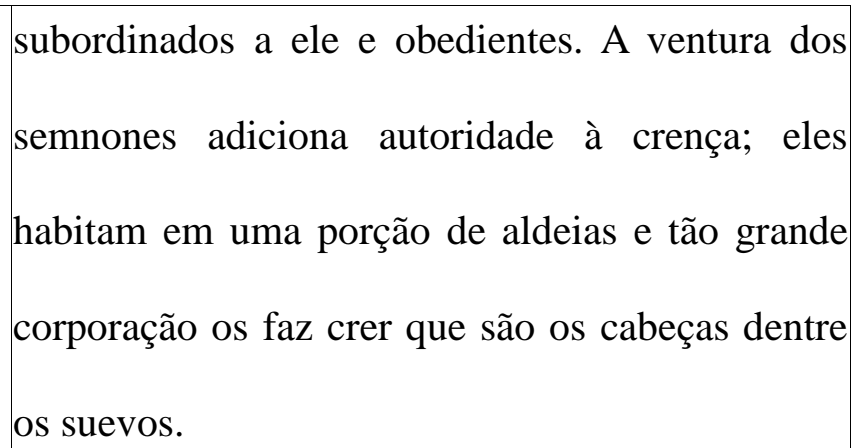

40. Contra Langobardos paucitas nobilitat: 40. Os langobardos, ao contrário, enobrecem-se plurimis ac valentissimis nationibus cincti non por serem poucos. Rodeados por nações muito per obsequium, sed proeliis ac periclitando tuti numerosas e valentes, eles não estão a salvo sunt. Reudigni deinde et Aviones et Anglii et graças à submissão e sim às batalhas, e por Varini et Eudoses et Suarines et Nuitones exporem-se ao perigo.

fluminibus aut silvis muniuntur. nec quicquam A seguir vêm os reudignos, os aviões, os anglos, notabile in singulis, nisi quod in commune os varinos, os eudoses, os suardones e os Nerthum, id est Terram matrem, colunt eamque nuítones, todos estes fortificados com rios ou intervenire rebus hominum, invehi populis florestas. Nenhum destes é particularmente arbitrantur. est in insula Oceani castum nemus, notável, exceto pelo culto comum a Nerto, a mãe dicatumque in eo vehiculum, veste contectum; terra, que pode, segundo crêem, intervir em attingere uni sacerdoti concessum. is adesse questões humanas e investir contra as populações. penetrali deam intellegit vectamque bubus Em uma ilha do Oceano há um bosque sagrado e feminis multa cum veneratione prosequitur. laeti lá existe um carro consagrado, coberto por um tunc dies, festa loca, quaecumque adventu véu; apenas um sacerdote pode tocá-lo. Ele hospitioque dignatur. non bella ineunt, non arma percebe a presença da deusa em seu santuário e sumunt; clausum omne ferrum; pax et quies acompanha com muita veneração, ela ser tunc tantum nota, tunc tantum amata, donec transportada por vacas. Então os dias são felizes, idem sacerdos satiatam conversatione há festividades em todo lugar que ela julga digno mortalium deam templo reddat. mox vehiculum para ir e hospedar-se. Eles não vão a guerras e 
et vestis et, si credere velis, numen ipsum não pegam em armas, todas as espadas são secreto lacu abluitur. servi ministrant, quos guardadas. Só neste momento a paz e o sossego statim idem lacus haurit. arcanus hinc terror são conhecidos e amados; até que o mesmo sanctaque ignorantia, quid sit illud, quod tantum sacerdote leve de volta ao seu templo a deusa, já perituri vident. saciada do convívio com os mortais. Logo depois, o carro, o véu e, se você quiser acreditar, a própria divindade são banhados em um lago secreto. Os escravos fazem o serviço e sem demora são engolidos pelo mesmo lago. Daí o misterioso terror e o santo desconhecimento sobre o que acontece nesse rito, só assistido por aqueles que vão morrer.

41. Et haec quidem pars Sueborum in secretiora 41. Esta parte dos suevos estende-se pelos rincões Germaniae porrigitur: propior, ut, quo modo mas remotos da Germânia. A mais próxima a nós Paulo ante Rhenum, sic nunc Danuvium sequar, - para seguir agora pelo Danúbio, como há pouco Hermundurorum civitas, fida Romanis; eoque fiz com o Reno - é a Cidade dos hermúnduros, solis Germanorum non in ripa commercium, sed leal aos romanos; dos germanos, apenas com eles penitus atque in splendidissima Raetiae comercializamos não só às margens do rio, mas provinciae colonia. passim sine custode também ao longe, na esplendorosa colônia da transeunt; et cum ceteris gentibus arma modo província da Récia. Eles transitam para cá e para castraque nostra ostendamus, his domos lá sem serem vigiados; e enquanto expomos aos villasque patefecimus non concupiscentibus. in outros povos tão somente nossas armas e fortes, a Hermunduris Albis oritur, flumen inclutum et estes nós mostramos nossas casas e vilas, porque notum olim; nunc tantum auditur.

não as cobiçam. No território dos hermúnduros nasce o Elba, outrora um rio célebre 
reconhecido, atualmente apenas conhecem-no de nome.

42. Iuxta Hermunduros Naristi ac deinde 42. Perto dos hermúnduros vivem os naristos e, Marcomani et Quadi agunt. Praecipua mais adiante, os marcomanos e os quados. A Marcomanorum gloria viresque, atque ipsa glória e a força dos marcomanos são notáveis, sua etiam sedes pulsis olim Boiis virtute parta. nec própria região foi obtida pela coragem quando, Naristi Quadive degenerant. eaque Germaniae antigamente, expulsaram de lá os boios. Os velut frons est, quatenus Danuvio praecingitur. naristos e os quados equiparam-se a eles, povos Marcomanis Quadisque usque ad nostram estes que são como a fronte da Germânia até onde memoriam reges manserunt ex gente ipsorum, o Danúbio a cerca. Os marcomanos e os quados, nobile Marobodui et Tudri genus (iam et até os nossos dias, mantiveram-se reis de seus externos patiuntur), sed vis et potentia regibus próprios povos, como as nobres famílias de ex auctoritate Romana. raro armis nostris, Moroboduo e de Tudri (mas já admitem saepius pecunia iuvantur, nec minus valent.

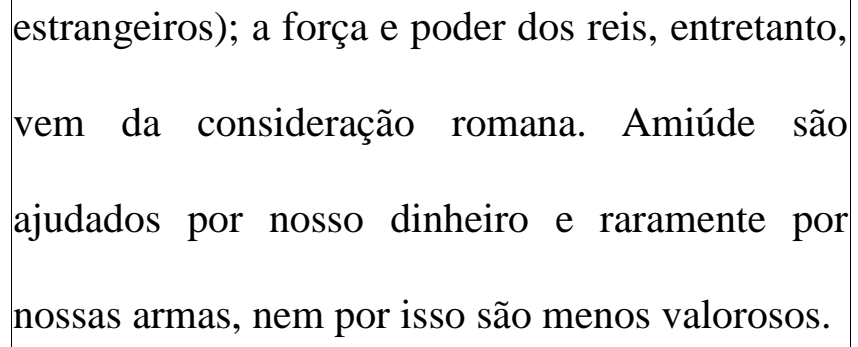
estrangeiros); a força e poder dos reis, entretanto, vem da consideração romana. Amiúde são ajudados por nosso dinheiro e raramente por nossas armas, nem por isso são menos valorosos.

43. Retro Marsigni, Cotini, Osi, Buri terga 43. Os marsignos, os gotinos, os osos e os búrios Marcomanorum Quadorumque claudunt. e encerram-se às costas dos marcomanos e dos quibus Marsigni et Buri sermone cultuque quados. Destes, os marsignos e os búrios Suebos referunt: Cotinos Gallica, Osos parecem-se com os suevos na linguagem e nos Pannonica língua coarguit non esse Germanos, costumes. A língua gaulesa dos gotinos e a língua et quod tributa patiuntur. partem tributorum panônia dos osos provam que eles não são Sarmatae, partem Quadi ut alienigenis germanos, por isso aturam os tributos. Parte dos imponunt: Cotini, quo magis pudeat, et ferrum tributos é imposta pelos sármatas e parte pelos 
effodiunt. omnesque hi populi pauca quados, para quem eles são estrangeiros. Os campestrium, ceterum saltus et vertices gotinos ainda mineram ferro, o que é mais montium [iugumque] insederunt. dirimit enim vergonhoso. Todas essas populações possuem scinditque Suebiam continuum montium iugum, poucas planícies, habitam então desfiladeiros e o ultra quod plurimae gentes agunt, ex quibus topo das montanhas. Pois divide e separa a latissime patet Lugiorum nomen in plures Suévia uma cadeia de montanhas, para além da civitates diffusum. valentissimas nominasse qual vivem miríades de povos; dentre eles, o sufficiet, Harios, Helveconas, Manimos, nome mais amplamente divulgado é o dos lígios, Helisios, Naharvalos. apud Naharvalos antiquae que se estendem por muitas Cidades. Bastará ter religionis lucus ostenditur. praesidet sacerdos nomeado as mais fortes: os hários, os helveconas, muliebri ornatu, sed deos interpretatione os manimos, os helísios e os naarvalos. Entre os Romana Castorem Pollucemque memorant. ea naarvalos apresenta-se um bosque sagrado de vis numini, nomen Alcis. nulla simulacra, uma antiga religião: um sacerdote preside o ritual nullum peregrinae superstitionis vestigium; ut vestido de mulher, mas segundo a interpretação fratres tamen, ut iuvenes venerantur. ceterum romana, referem-se ao culto aos deuses Castor e Harii super vires, quibus enumeratos paulo ante Pólux. Tal a natureza daquela divindade, cujo populos antecedunt, truces insitae feritati arte ac nome é Alcos. Não utilizam imagens e não há tempore lenocinantur: nigra scuta, tincta vestígio de nenhuma crença estrangeira; no corpora; atrás ad proelia noctes legunt ipsaque entanto, essas duas divindades são veneradas formidine atque umbra feralis exercitus como jovens irmãos. Quanto aos hários, além da terrorem inferunt, nullo hostium sustinente força, que excede a das populações enumeradas novum ac velut infernum adspectum; nam primi pouco antes, eles são ferozes e aumentam seu in omnibus proeliis oculi vincuntur. aspecto selvagem por meio de artifícios e do Trans Lugios Gotones regnantur, paulo iam momento certo. Os escudos são enegrecidos e os adductius quam ceterae Germanorum gentes, corpos pintados; escolhem noites sem lua para as 
nondum tamen supra libertatem. protinus deinde batalhas e causam terror usando o próprio medo e ab Oceano Rugii et Lemovii; omniumque harum as sombras deste exército funesto. Nenhum gentium insigne rotunda scuta, breves gladii et inimigo suporta a nova e, por assim dizer, erga reges obsequium. infernal aparência.

Para além dos lígios, há o reinado dos gotões; seu soberano governa mais duramente que o dos outros povos germanos, mas não a ponto de suprimir a liberdade. Logo em seguida e ao lado do Oceano estão os rúgios e os lemóvios. São sinais distintivos de todos estes povos os escudos redondos, os gládios curtos e a obediência aos reis.

44. Suionum hinc civitates, ipso in Oceano, 44. Adiante há as Cidades dos suiones, praeter viros armaque classibus valent. forma localizadas no próprio Oceano e vigorosas por navium eo differt, quod utrimque prora paratam seus homens, armas e, sobretudo, por suas frotas. semper adpulsui frontem agit. nec velis A estrutura de seus navios é diferente da dos ministrant nec remos in ordinem lateribus demais, porque existe proa em ambas as pontas, adiungunt: solutum, ut in quibusdam fluminum, então a parte frontal está sempre preparada para o et mutabile, ut res poscit, hinc vel illinc impulso. Não os dirigem à vela nem fixam remos remigium. est apud illos et opibus honos, eoque em fileiras às laterais; seguem a velas soltas, unus imperitat, nullis iam exceptionibus, non como se faz em certos rios, mas o curso pode ser precario iure parendi. nec arma, ut apud ceteros alterado para qualquer direção, conforme a Germanos, in promisco, sed clausa sub custode, ocasião exigir. Entre eles há consideração pela et quidem servo, quia subitos hostium incursus riqueza e um homem apenas manda, sem prohibet Oceanus, otiosae porro armatorum quaisquer restrições e com direito irrevogável à 
manus facile lasciviunt: enimvero neque obediência. As armas não são carregadas em nobilem neque ingenuum, ne libertinum quidem público, como se vê nos demais povos germanos, armis praeponere regia utilitas est. mas ficam trancadas e sob a proteção de um guarda, seguramente um escravo; porque o Oceano impede a súbita incursão do inimigo e, além disso, as mãos desocupadas dos homens armados facilmente cometem excessos; sem dúvida, não é útil ao rei armar um nobre, um homem livre ou mesmo um liberto.

45. Trans Suionas aliud mare, pigrum ac prope 45. Para lá dos suiones há outro mar, preguiçoso inmotum, quo cingi claudique terrarum orbem e quase imóvel, que rodeia e cerca o mundo; a hinc fides, quod extremus cadentis iam solis prova disto é que o último brilho do sol ao se pôr fulgor in ortum edurat adeo clarus, ut sidera continua claro até o nascer novamente do sol, de hebetet; sonum insuper emergentis audiri modo que ofusca as estrelas; a crença ainda formasque equorum et radios capitis adspici acrescenta que é possível ouvir o barulho de persuasio adicit. illuc usque, et fama vera, quando ele emerge e ver as imagens dos cavalos e tantum natura. ergo iam dextro Suebici maris os raios de sua cabeça.

litore Aestiorum gentes adluuntur, quibus ritus Tão somente até ali, e os boatos são verdadeiros, habitusque Sueborum, língua Britannicae chega a natureza. Portanto, agora iremos para o propior. matrem deum venerantur. insigne litoral à direita do mar dos suevos, onde são superstitionis formas aprorum gestant: id pro banhados os povos estios, cujos costumes e armis hominumque tutela securum deae aparência são suevos, mas a linguagem é mais cultorem etiam inter hostes praestat. rarus ferri, próxima à britânica. Eles veneram a mãe dos frequens fustium usus. frumenta ceterosque deuses. Como símbolo desta superstição, fructus patientius quam pro solita Germanorum carregam imagens de javalis; isto substitui armas 
inertia laborant. sed et mare scrutantur, ac soli e a proteção dos homens, mantém seguro o omnium sucinum, quod ipsi glesum vocant, adorador da deusa mesmo em meio a inimigos. $\mathrm{O}$ inter vada atque in ipso litore legunt. nec quae uso de espadas é raro, mas o de bastões é natura quaeve ratio gignat, ut barbaris, freqüente. Cultivam grãos e outros frutos da terra quaesitum compertumve; diu quin etiam inter mais pacientemente que pela costumeira inércia cetera eiectamenta maris iacebat, donec luxuria dos germanos. E também exploram o mar, são os nostra dedit nomen. ipsis in nullo usu: rude únicos germanos a recolher o âmbar, chamado legitur, informe perfertur, pretiumque mirantes por eles de glesum, do fundo do mar e da própria accipiunt. sucum tamen arborum esse intellegas, praia. Com qual substância e por qual método quia terrena quaedam atque etiam volucria cria-se esse material, eles não investigaram ou animalia plerumque interiacent, quae implicata descobriram, já que são bárbaros. Porém, durante humore mox durescente materia clauduntur. muito tempo ficou misturado aos outros resíduos fecundiora igitur nemora lucosque sicut Orientis marinhos, até que nossa luxúria o nomeou. Não secretis, ubi tura balsamaque sudantur, ita possui utilidade para eles; recolhem-no bruto, Occidentis insulis terrisque inesse crediderim, trazem-no sem forma e admiram-se ao receber o quae vicini solis radiis expressa atque liquentia pagamento. Você pode conceber que o âmbar seja in proximum mare labuntur ac vi tempestatum produto da seiva das àrvores, porque certos in adversa litora exundant. si naturam sucini animais terrestres e mesmo voadores geralmente admoto igni temptes, in modum taedae são encontrados no meio dela: pegados ao accenditur alitque flammam pinguem et líquido, logo ficam presos à matéria endurecida. olentem; mox ut in picem resinamve lentescit. Eu poderia pensar, portanto, que assim como em Suionibus Sitonum gentes continuantur. cetera recônditos locais do oriente são produzidos similes uno differunt, quod femina dominatur: incensos e bálsamo, há nas ilhas e terras do in tantum non modo a libertate sed etiam a ocidente florestas e bosques muito mais férteis, servitute degenerant. que são comprimidos e liquefeitos pelos raios do 
sol quando este se avizinha; essa seiva escorre até
o mar mais próximo e, pela força das
tempestades, é carregada às praias opostas. Se
você testar as propriedades do âmbar levando-o
ao fogo, verá que ele queima como uma tocha e
desenvolve uma chama oleosa e odorífera; logo
quando amolece transforma-se em pez ou resina.
Os povos sítones confinam com os suiones. Em
tudo o mais semelhantes, diferem deles apenas
em um ponto: a mulher é quem manda; desta
forma degenera-se não só a liberdade, como
também a escravidão.

46. Hic Suebiae finis. Peucinorum 46. Aqui termina a Suévia. Estou em dúvida se Venethorumque et Fennorum nationes Germanis referirei as nações dos peucenos, dos vênedos e an Sarmatis adscribam dubito, quamquam dos fenos como germanos ou sármatas, embora Peucini, quos quidam Bastarnas vocant, os peucenos, chamados de bastarnas por alguns, sermone cultu, sede ac domiciliis ut Germani sejam como os germanos na linguagem, agunt. sordes omnium ac torpor procerum; aparência, por fixar moradia e pelo tipo de conubiis mixtis nonnihil in Sarmatarum habitum habitação. Todos são sujos e os chefes indolentes; foedantur. Venethi multum ex moribus por conta dos casamentos entre os povos, eles traxerunt; nam quidquid inter Peucinos recebem alguma coisa do aspecto horrível dos Fennosque silvarum ac montium erigitur sármatas. Os vênedos contraíram muitos de seus latrociniis pererrant. hi tamen inter Germanos costumes; com seus assaltos, percorrem todas as potius referuntur, quia et domos figunt et scuta florestas e montanhas que se elevam entre os gestant et pedum usu et pernicitate gaudent: peucenos e os fenos. No entanto, estes povos são 
quae omnia diversa Sarmatis sunt in plaustro preferencialmente mencionados como germanos, equoque viventibus. Fennis mira feritas, foeda pois fixam domicílio, levam escudos e alegram-se paupertas: non arma, non equi, non penates; por usarem os pés e pela velocidade da corrida. victui herba, vestitui pelles, cubile humus: solae Em tudo isso diferem dos sármatas, que passam a in sagitiis spes, quas inopia ferri ossibus vida andando de carro ou a cavalo. Os costumes asperant. idemque venatus viros pariter ac selvagens dos fenos são espantosos e sua pobreza feminas alit; passim enim comitantur partemque vergonhosa: não possuem armas, cavalos ou praedae petunt. nec aliud infantibus ferarum penates. Eles utilizam ervas como alimento, peles imbriumque suffugium quam ut in aliquo como vestes e o chão como leito. Sua única ramorum nexu contegantur: huc redeunt esperança reside nas flechas; na falta do ferro, iuvenes, hoc senum receptaculum. sed beatius fazem suas pontas com ossos. O mesmo tipo de arbitrantur quam ingemere agris, inlaborare caça alimenta igualmente homens e mulheres, domibus, suas alienasque fortunas spe metuque pois elas os acompanham por toda parte e pedem versare; securi adversus homines, securi um quinhão da presa. E não há outro abrigo adversus deos rem difficillimam adsecuti sunt, contra as feras e as chuvas para as crianças a não ut illis ne voto quidem opus esset. cetera iam ser a proteção de algum entrelaçamento de fabulosa: Hellusios et Oxionas ora hominum galhos; para lá voltam os jovens, lá é o refúgio voltusque, corpora atque artus ferarum gerere: dos velhos. Mas acreditam haver mais felicidade quod ego ut incompertum in medio relinquam.

nisso que em gemer trabalhando nos campos, construir suas casas e ficar de olho, por esperança ou medo, em sua fortuna e na alheia. Tranquilos com relação aos homens, tranquilos com relação aos deuses, alcançaram algo dificílimo: eles não têm necessidade nem de fazer pedidos. Já o restante é fabuloso: que os helúsios e os oxiões 
têm rostos e expressões humanas, mas corpos e membros de feras; questão que eu deixarei em aberto, já que não foi esclarecida. 


\section{COMENTÁRIOS}

Capítulo I. Sobre a construção da monografia etnográfica em Germania

\section{I.1 A tradição etnográfica e a história}

A etnografia não era considerada entre os antigos gregos e romanos um gênero literário como a épica, a tragédia ou a historiografia, nem essa nomenclatura era atribuída aos textos que hoje consideramos etnográficos, apesar de sua origem grega. A recorrência de elementos particulares e sua organização textual indicam a existência de uma tradição etnográfica.

Em sua introdução à tradução de Germania, J. B. Rives aponta como provável obra inaugural da tradição etnográfica Periegesis (ao redor do mundo) de Hecateu de Mileto, datada do século V a. C., a partir da qual é possível identificar três formas em que essa tradição se desenvolveu: a periegese, a monografia etnográfica e a etnografia como digressão nas histórias (TACITUS, 2002). O autor de uma periegese é um viajante que descreve e tece comentários sobre as regiões por onde passa. Como exemplos deste tipo de literatura, citamos o Périplo atribuído a Silas, do séc. IV a.C., que discorre sobre povos, cidades e ilhas do mediterrâneo, o Périplo do Ponto Euxino e o Périplo do Mar Negro de Arriano e o Périplo do periegeta Dionísio, este último posterior a Tácito. ${ }^{17}$

A segunda parte de Germania, seguindo a divisão temática adotada e apresentada na introdução, aproxima-se da escrita periegética.

Quanto a monografias etnográficas, as primeiras de que se tem notícia, segundo Rives, são Aigyptiaka e Persika de Helânico de Lesbos e Lydiaka de Xanto, o Lídio, ambos

\footnotetext{
${ }^{17}$ Cf. MÜLLER, C. (ed.). Geographi graeci minoris. Paris: Firmin-Didot, 1882.
} 
coetâneos de Heródoto (TACITUS, 2002). Em Aigyptiaka são apresentadas as propriedades da terra e os costumes de seus habitantes, em Persika, os mitos fundadores e uma história da dinastia real, e em Lydiaka, seu passado legendário e histórico.

Todavia, entre Germania e as monografias etnográficas como Persika e Aigyptiaka há apenas em comum a estruturação monográfica e o tema principal voltado à descrição de um povo, pois nessas o mítico e a geografia ocupam papel de destaque, enquanto em Germania, as informações geográficas da região são sucintas e ocupam pequeno espaço na obra e o mítico é restrito à questão da origem da gente (TRÜDINGER, 1918, p. 147).

Segundo nos informa Fraser (1972, p. 496), o círculo de Calímaco demonstrava pouco interesse por povos não-gregos, com exceção daqueles que pertenciam ao mundo homérico e épico; o historiador Hecateu de Abdera representou uma visão diferente ao escrever uma obra sobre as antiguidades egípcias, provavelmente intitulada Sobre os egípcios. Esta obra não chegou até nós, mas muitos excertos são incorporados no primeiro livro da História de Diodoro e por meio dele somos informados das seções em que se dividia o texto de Hecateu, consideradas características da escrita etnográfica (FRASER, 1972), que são: cosmologia e teologia nativas, geografia do Egito, governadores do local e costumes. Com exceção da segunda seção, as demais apresentam diversos trechos em que se abriu espaço para o contraste entre a cultura oriental e a grega, cujo resultado sempre favorecia os egípcios e não seu próprio povo. De acordo com Fraser (1972, p. 497):

Com exceção da segunda, cada uma dessas fornece grande oportunidade, não para especulações filosóficas abstratas, mas para contrastar as noções orientais e gregas (um contraste que Hecateu faz com frequência), (...) nós 
vemos a partir de Diodoro que ele ansiava por demonstrar tanto a antiguidade quanto a superioridade da cultura egípcia. ${ }^{18}$

Na primeira seção, por exemplo, Diodoro aponta para o fato de que os deuses gregos seriam derivações dos deuses egípcios, bem como seus mitos, e na seção sobre os costumes egípcios, Diodoro diz:

Os gregos depositaram sua convicção sobre essas coisas, a saber, a honra dos bons e o castigo dos maus, em mitos inventados e em relatos desacreditados; assim, estas coisas não só não podem influir para levar os homens a uma vida melhor, como também, ao contrário, recebem muito desprezo, ridicularizadas pelos maus; mas entre os egípcios, não sendo mitológico e sim visível o castigo dos maus e a honra dos bons, ambos lembram-se a cada dia do conveniente e, dessa forma, produz-se a maior e mais proveitosa correção de seus hábitos. ${ }^{19}$

A Germania de Tácito situa-se na tradição desta literatura etnográfica da qual os grandes nomes são Homero, Hecateu, Heródoto, Teopompo e Posidônio; com exceção de Hecateu, os demais escreveram textos etnográficos para inserir e compor o todo de suas obras, história ou épica, como digressões. Para Syme (1958), a Germania é única, mas não é original. Muitos historiadores já haviam se exercitado neste campo e estabelecido uma longa tradição. Em seu estudo introdutório à tradução de Germania, Perret afirma que esta literatura fornece a Tácito, além de informações e um molde estrutural para o desenvolvimento do texto, recorrentes teorias (TACITE, 1949). Uma delas associa o povo ao local em que ele mora, ou seja, seu tipo físico e características psicológicas refletiriam as peculiaridades da

\footnotetext{
${ }^{18} \mathrm{~A}$ tradução das citações ao longo do trabalho é de responsabilidade do autor.

${ }^{19}$ Tradução do espanhol (DIODORO DE SICILIA, 2011, p. 311).
} 
região habitada. Perret informa-nos que esta teoria antropogeográfica foi sistematizada pela primeira vez no século $\mathrm{V}$ a. C. pelo autor do tratado $\Pi \varepsilon \rho i ̀ ~ \alpha \dot{\varepsilon ́ \rho} \omega v, \dot{v} \delta \dot{\alpha} \tau \omega v$, $\tau o ́ \pi \omega v$ que figura na coleção hipocrática. Heródoto, ao tratar dos egípcios em Histórias II, 35, apresenta-se adepto a essa ideia: "Os egípcios possuem um clima peculiar e um rio cuja natureza o diferencia de todos os outros e, além disso, criaram muitos hábitos e costumes que são quase completamente opostos ao do restante da humanidade". De Germania, podemos citar alguns trechos que demonstram a filiação de Tácito a essa teoria: "graças ao clima e ao terreno habituaram-se ao frio e à fome” (IV, 3); "no mais são similares aos batavos, sem contar que em sua terra recebem maior disposição do solo e do clima" (XXIX, 3). Também de sua obra Agricola citamos um exemplo: "o clima configurou seu estado físico" (XI, 2$)^{20}$.

Outra teoria diz respeito à excelência do estado primitivo da natureza humana, enquanto a civilização representaria a corrupção dos valores inerentes a este estado. Essa tendência de idealizar os povos "bárbaros", de acordo com Perret (TACITE, 1949), vai se afirmar a partir do século IV e principalmente na obra de Éforo. Em Germania, Tácito apresenta os costumes rudes dos germanos, inclinado a admirá-los e não a criticá-los por sua barbárie, como faria um etnógrafo moderno. Esta propensão a valorar o primitivo povo germano seria proveniente da idealização do natural, que era como uma das preceptivas do gênero. Perret, a esse respeito, afirma: "há um certo colorido idealizante que é como uma lei do gênero e que nos revela, portanto, pouca coisa sobre a personalidade ou intenções de Tácito”. Syme (1958) afirma, para além de se tratar de um tópico recorrente, que a idealização do selvagem cria uma imagem de virtude e felicidade primitiva, a qual inevitavelmente censura, direta ou indiretamente, a luxúria e a corrupção da vida urbana.

Perret expõe ainda que também faz parte da tradição etnográfica a reflexão sobre as questões de origem. E de todos os povos convém questionar se é autóctone, imigrante ou

\footnotetext{
${ }^{20}$ seu... positio caeli corporibus habitum dedit.
} 
composto de uma mistura de autóctones e de imigrantes (TACITE, 1949). Tácito não deixa de evocar essas três possibilidades, mas defende a suposição da autoctonia do povo germano, como vemos no início do parágrafo 2 (p. 10-11) de Germania, pois a região possui características que a tornam de difícil acesso e nada atrativa para se habitar.

Considerando essa hipótese, sob a análise de Perret, os germanos seriam provenientes de uma origem comum e como um único grande grupo, que se desenvolverá separadamente, se faz reconhecer por traços comuns: língua, costumes e tipo físico (TACITE, 1949). A fórmula que Tácito aplica aos germanos já havia sido utilizada por pseudo-Hipócrates que afirma, no capítulo 19, que o povo cita diferencia-se bastante dos demais e é apenas parecido a si mesmo, como os egípcios ${ }^{21}$.

Em relação à natureza de Germania, não há muitas discussões entre seus estudiosos desde a publicação dos trabalhos de Trüdinger (1918) e Norden (1920), segundo Rives, pois a maioria reconheceu-na como monografia etnográfica (TACITUS, 2002). Reconhecemos que essa obra de Tácito aproxima-se, por suas características, de uma monografia etnográfica, entretanto, pensamos que classificar Germania é simplificar uma obra que é deveras rica em termos de gênero e que, portanto, não se permite enquadrar em um molde rígido de definição. Ademais, colocá-la no mesmo conjunto "monografias etnográficas" em que estão Lydiaka e Persika seria admitir sua total afinidade. Então, nossa intenção não é procurar um rótulo para Germania, e sim discutir sua composição genérica.

As propostas anteriores de classificá-la como história local ou geografia foram insatisfatórias, porque a obra apresenta poucos detalhes históricos ou topográficos (RIVES, 1999, p. 50). A questão geográfica está restrita ao início da obra (parágrafo 1) e a poucas e pontuais menções ao longo do texto (30. 1 durant siquidem colles, paulatim rarescunt, et Chattos suos saltus Hercynius prosequitur simul atque deponit; 35.1 in septentrionem ingenti

\footnotetext{
${ }^{21}$ Apud NORDEN (1920)
} 
flexu recedit; 41.2 in Hermunduris Albis oritur; 43.2 dirimit enim scinditque Suebiam continuum montium iugum). Diferentemente de Estrabão ou Ptolomeu, Tácito tende a localizar uma natio em particular por referência a outras nationes e não por características topográficas, e os detalhes topográfios que surgem são pouquíssimos e muito vagos.

Outrossim a classificação de Germania como história local é inadequada para Rives, já que a obra contém poucos detalhes históricos. Tácito faz alguns apontamentos sobre a origem e movimentos de certas nationes, como os helvécios e os boios (28.2), mas deixa de lado encontros militares com os romanos, mesmo sendo estes recentes, dentre os quais a guerra de Domiciano com os catos e a insurreição dos queruscos sob Armínio; e ao invés disso, ele insere um sumário relâmpago dessas guerras no capítulo sobre os cimbros (37. 2-5) (TACITUS, 2002). Por relatos históricos políticos e descrições geográficas estarem pouco presentes na obra, essa se diferencia das monografias etnográficas e obras de cunho periegético tradicionais, que davam ênfase a essas questões.

Na opinião de Rives (TACITUS, 2002), as monografias etnográficas tradicionais costumavam retratar sociedades urbanas complexas, como aquela dos egípcios e a dos persas, mas se houvesse mais evidências para monografias contemporâneas sobre outras sociedades tribais, como aquela do orador grego Dion de Prusa sobre os getas (FgrH 707) ou aquela de Arriano sobre os alanos (FgrH 156 F12-13), Germania poderia parecer menos incomum.

Ao buscar compreender essa obra de Tácito do ponto de vista do gênero literário, uma questão maior e mais complexa apresenta-se, a da classificação da própria etnografia. A etnografia não foi considerada um gênero entre os antigos, mas será que podemos vê-la assim agora, tal como a epistolografia? Se sim, Germania não deveria ser encarada como uma peça historiográfica. Porém, as monografias etnográficas muito se aproximavam de história, como vimos acima, apesar de não serem vistas como uma e mesma coisa, e aqui citamos Momigliano (2004, p. 92): 
Autores de história local, de cronografias, genealogias, dissertações eruditas, obras etnográficas, quaisquer que fossem seus méritos, não se qualificavam como verdadeiros historiadores. É suficiente que nos lembremos de que a lista dos historiadores importantes em Quintiliano inclui, entre os gregos, Heródoto, Tucídides, Xenofonte, Teopompo, Éforo, Filisto, Clitarco e Timagenes.

E também pela forma como a etnografia desenvolveu-se, como digressões nas histórias, seria mais adequado defini-la espécie da história. Desta forma, pensamos que uma monografia etnográfica é uma monografia histórica com viés etnográfico. De toda maneira, a construção de Germania é incomum, mas este fato dentro do conjunto das obras de Tácito não é tão insólito, dado o caráter experimental que perpassa por todas essas (MOMIGLIANO, 2004, p. 163).

De acordo com Rives, tanto a monografia quanto a digressão etnográfica, a despeito de suas diferenças, possuem um certo número de elementos típicos, pois sua ocorrência é regular (TACITUS, 2002, p. 15):

O único tema invariável é o próprio povo, incluindo sua origem, suas características físicas e seus costumes religiosos, sociais e militares; ao lado disso pode haver também a história da dinastia ou política. Outro tema recorrente é seu território: suas fronteiras, sua natureza e topografia, seu clima e recursos. 


\section{I.2 Digressões etnográficas}

A etnografia sói aparecer como digressão em obras historiográficas, tanto gregas quanto latinas. Heródoto a utilizou em alguns momentos em suas Histórias, mais completamente no livro 2 (2-182) ao tratar do Egito e no livro 4, ao tratar da Cítia (5-82) e da Líbia (168-99). E todas elas baseadas em investigações do próprio historiador, que foi até esses locais.

Também Júlio César em seus Comentarii de Bello Gallico faz digressões etnográficas, que versam sobre o povo britano, o gaulês e o germano, de acordo com experimentações pessoais. Heródoto e César, portanto, são testemunhas oculares dos fatos que narram, uma constante do gênero historiográfico desde Políbio. Segundo Gudeman (1900), o registro de César sobre a vida e os costumes germânicos é o mais antigo dentre os romanos. Quanto ao conteúdo, Germania apresenta muitos pontos que se aproximam bastante da descrição de César dos germanos, a saber, a dedicação somente à guerra e caçadas, a questão da castidade na juventude, do vestuário, da agricultura, da alimentação, da divisão de terrenos, do estabelecimento da moradia e da hospitalidade.

Na digressão sobre os germanos feita em De Bello Gallico, VI há os seguintes trechos, que recortamos para compará-los a algumas passagens de Germania:

21. 3 Toda sua vida consiste em caçadas e dedicação à arte militar: desde pequenos dedicam-se ao esforço e à dureza. 4. Os que permanecem castos por mais tempo gozam o maior louvor entre os seus: julgam desenvolver com isto a estatura, desenvolver as forças e fortalecer os nervos.

5. Têm, positivamente, como uma das maiores torpezas conhecer a mulher antes dos vinte anos. Do fato, não há qualquer segredo, porque tanto se 
banham promiscuamente nos rios como usam peles ou pequenos agasalhos [de pêlos], desnuda a maior parte do corpo.

22.1 Não se interessam pela agricultura, e a maior parte do seu alimento consiste em leite, queijo, carne. E ninguém tem um tamanho certo de campo ou territórios próprios; mas os magistrados e os chefes atribuem, para cada ano, às famílias e às comunidades de homens que então se reuniram, um campo do tamanho e no lugar que lhes parece bem: e, um ano após outro, obrigam-nos a partir.

3 Disso muitas são as causas que apresentam: (...) para que não surja a ambição de dinheiro (...).

23. 1 Para as cidades o maior louvor é ter desertos, o mais amplamente possível devastados, os territórios ao seu redor.

9 Não julgam piedoso violar um hóspede. Os que, por qualquer motivo, lhes chegam, protegem-nos contra a injustiça, têm-nos por sagrados: abrem-selhes as casas de todos e se partilha o alimento. ${ }^{22}$

De Germania são os excertos a seguir, que tratam de notícias similares às de César, apresentadas por nós na mesma ordem que apareceram acima nos Comentarii:

\section{Quotiens bella non ineunt, multum venatibus}

Todas as vezes que não vão para a guerra, dedicam-se muito às caçadas

\section{0. (...)sera iuvenum venus, eoque inexhausta pubertas}

A vida sexual dos jovens demora a começar e por isso a mocidade é vigorosa.

${ }^{22}$ Tradução de M. G. NOVAK. In: NOVAK, M. DA G.; NERI, M. L.; PETERLINI, A. A. (org.). Historiadores latinos: antologia bilíngue. 3. ed. São Paulo: Martins Fontes, 1999. 
17. Tegumen omnibus sagum fíbula aut, si desit, spina consertum: Cetera intecti totos dies iuxta focum. (...) gerunt et ferarum pelles

Todos vestem um saio fechado com uma fivela ou, na falta desta, com um espinho; nus quanto ao mais, passam dias inteiros junto ao calor do fogo. (...) Também trazem em si peles de fera

14. (...) nec arare terram aut exspectare annum tam facile persuaseris quam vocare hostem et vulnera mereri. pigrum quin immo et iners videtur sudore adquirere quod possis sanguine parare.

Não os convencerias a arar a terra ou a esperar pela colheita tão facilmente como a desafiar o inimigo e conseguir ferimentos. Mas antes consideram improdutivo e sem valor adquirir pelo suor aquilo que pode ser alcançado pelo sangue.

23 (...) cibi simplices, agrestia poma, recens fera aut lac concretum As refeições são simples, frutas do campo, carne fresca, leite coalhado

26. Faenus agitare et in usuras extendere ignotum; ideoque magis servatur quam si vetitum esset. Agri pro numero cultorum ab universis in vices occupantur, (...). arva per annos mutant, et superest ager.

É desconhecida a prática da usura e o acúmulo de dinheiro por juros, por isso tal atitude é mais observada do que se fosse proibida. Os campos são, sucessivamente, ocupados por todos os agricultores, (...). Mudam de terreno ano a ano e ainda sobra campo a cultivar.

16. (...) vicos locant non in nostrum morem conexis et cohaerentibus aedificiis: suam quisque domum spatio circumdat 
Estabelecem povoados não com edificações contíguas e conjugadas, segundo é nosso costume, mas cada qual circunda sua casa com um espaço

21. (...) convictibus et hospitiis non alia gens effusius indulget. Quemcumque mortalium arcere tecto nefas habetur; pro fortuna quisque apparatis epulis excipit.

Nenhum outro povo concede tão abundantemente familiaridade e hospitalidade. É considerado crime negar abrigo a qualquer ser humano; cada um, conforme suas posses, acolhe com um magnificente banquete.

Que Tácito conhecia os Comentarii de César é certo, e não apenas pelas semelhanças das informações entre um e outro texto. No parágrafo 28 de Germania há uma menção explícita à obra de Júlio César:

28. Validiores olim Gallorum res fuisse summus auctorum Divus Iulius tradit

O divino Júlio, o melhor dentre os escritores, relata que a posição dos gauleses, outrora era mais forte

Há inclusive uma semelhança na escrita de uma sentença em Germania, que aponta para a deliberação de Tácito de explicitar sua alusão a César. De Germania é a frase: deorum maxime Mercurium colunt (dentre os deuses, cultuam sobretudo Mercúrio); a frase que aparece nos Comentarii de Bello Gallico VI. 17,1 de César é: deum maxime Mercurium colunt, que poderíamos verter como "cultuam, sobretudo, o deus Mercúrio". A única diferença é o caso e número da palavra deus, que em César é acusativo singular e em Tácito genitivo plural, mas ainda assim ambas as frases mantêm o mesmo significado, lembrando que Tácito está se referindo aos germanos e César aos gauleses. 
Isso implicaria dizer, de certa forma, que esta seria uma maneira de Tácito demonstrar a quem está emulando. A questão da emulação de Comentarii de Bello Gallico de César por Tácito é anunciada no início de sua obra. O parágrafo de abertura de Germania, que trata das delimitações geográficas da região conhecida como território germano, retoma o início do livro I dos Comentarii. Essa obra de César inicia-se pelo nome da região objeto de análise:

\section{Gallia est omnis (...)}

E com a mesma construção, Tácito abre Germania:

\section{Germania omnis (...)}

O nome da região do povo que será apresentado principia tanto os Comentarii De Bello Gallico quanto Germania, e ambas são seguidas por omnis. Na sequência, tanto o texto de César quanto o de Tácito buscam delimitar o território dos povos da Gália e dos povos germanos, respectivamente, indicando o que os separa dos demais povos, em geral, rios. Nos Comentarii César diz ser a Gália dividida em três partes: uma habitada pelos belgas, outra pelos aquitanos e a outra pelos celtas (gauleses). Os gauleses são separados dos aquitanos pelo rio Garona, dos belgas pelo Marne e Sena. Os belgas ficam próximos ao Reno e vivem em combate com os germanos. O território dos gauleses inicia no rio Ródano e é cercado pelo rio Garona, o Oceano e o território dos belgas; os sequanos e os helvécios ficam próximos ao Reno. Belgas e aquitanos são separados por rios e pelos Pirineus. Em Germania Tácito expõe, mais concisamente, o que delimita o território germano com relação aos povos que o cercam; Reno e Danúbio o separam dos gauleses, retos e panônios; as montanhas e o medo mútuo, dos sármatas e dácios e o Oceano o separa do restante. 
Mais à frente em nosso trabalho, nos comentários sobre as interpretações acerca da finalidade de Germania, discutimos a ausência de prefácio nessa obra de Tácito. Germania inicia-se abruptamente, sem um prefácio, seção importante e usual em obras historiográficas; entretanto, como vimos, Tácito começa sua obra ao modo dos Comentarii de César. E, de certa forma, a parte inicial de Germania faz às vezes de proêmio ao indicar ao leitor que o texto será uma monografia histórica sobre os germanos, por remeter à introdução aos Comentarii; porém, como ficamos sabendo posteriormente, essa inferência é aplicada apenas em linhas gerais.

No entanto, as informações sobre os germanos de um e outro divergem em alguns pontos, como, por exemplo, com relação à questão religiosa. César afirma em Comentarii de Bello Gallico, VI, 21 que os germanos não têm druidas para regular o culto divino, não zelam pelos sacrifícios; eles contam entre os deuses somente aqueles a quem podem ver e pelo ofício dos quais eles são abertamente assistidos, a saber, o Sol, o deus Fogo e a Lua, do restante, eles não conhecem nem por relato. Por Tácito somos informados que os germanos não só possuem sacerdotes (parágrafo 10 si publice sacerdos civitatis; sacerdos ac rex vel princeps; parágrafo 11 silentium per sacerdotes), como não cultuam o Sol, o deus Fogo ou a Lua. Dentre os deuses, diz-nos Tácito, os germanos cultuam, sobretudo, Mercúrio, mas também Hércules e Marte, e uma parte dos suevos cultua Ísis; também “consagram bosques e florestas e designam com nomes de deuses algo oculto, que vêem somente por meio da reverência" (parágrafo 9).

Em sua obra Agricola, cuja extensão é equivalente a de Germania e igualmente dividida em 46 parágrafos, Tácito constrói uma digressão etnográfica, que se estende do parágrafo 10 ao 12. Abaixo encontram-se o final do nono parágrafo, para observarmos a maneira como é introduzida a digressão, e trechos dos parágrafos que contêm a digressão, para podermos comparar os elementos ali utilizados e seu tratamento com os de Germania. 
(...) Para concluir sua função, ele colocou a mão dela sobre a minha e imediatamente depois foi enviado à Britânia, acompanhando esta promoção a função sacerdotal de pontifício.

10. A posição geográfica da Britânia e os povos que lá habitam têm sido registrados por muitos escritores: se eu trato deles não é pelo desafio da comparação em matéria de exatidão ou talento, mas porque foi Agricola quem os subjugou completamente: portanto, onde escritores mais antigos ornaram retoricamente um tema ainda legendário, será encontrada apenas uma confiável narração de fatos.

A Britânia é a maior ilha conhecida pelos romanos: com relação a sua extensão e posição, tem a Germânia a leste e a Espanha a oeste; ao sul podese até ver a Gália; o litoral norte não tem terras opostas a ele, mas é atingido pela imensidão do mar aberto. Lívio e Fábio Rústico, os mais minuciosos dos escritores antigos e modernos, respectivamente, compararam a forma da Britânia como um todo a uma escápula alongada ou a uma lâmina de machado. (...) Foi somente sob Agricola que frotas romanas pela primeira vez contornaram esta costa, a costa do mais remoto mar, e estabeleceram a insularidade da Britânia. (...)

11. Como quer que seja, a questão sobre quem foram os primeiros habitantes da Britânia ou se eles eram nativos ou imigrantes nunca recebeu atenção, como se poderia esperar de povos bárbaros. O físico deste povo apresenta muitas variantes, a partir das quais são feitas suposições: o cabelo ruivo e os largos lábios dos habitantes da Caledônia atesta sua origem germânica; as faces coradas dos sílures, seu cabelo em geral ondulado e a posição da Espanha no lado oposto a seu litoral, mostra a passagem dos iberos há tempos atrás e a ocupação desta área por eles; aqueles povos que estão próximos à Gália são também como os gauleses, quer porque a influência da 
hereditariedade persista quer porque em duas terras projetadas em direções opostas até que eles se encarem a condição climática estampa um tipo físico no corpo humano; mas, tendo uma visão geral do caso, nós podemos prontamente acreditar que os gauleses tomaram posse da ilha vizinha. Você encontraria lá cerimônias gaulesas e crenças religiosas gaulesas; a língua não é muito diferente (...)

12. Sua força reside em sua infantaria; mas certos povos lutam também em carros (...) raramente duas ou três Cidades se reunirão para expulsar um perigo comum; por isso, eles lutam individualmente e são coletivamente conquistados. O céu é obscurecido por nuvens e chuva constante, mas o frio não é rigoroso. A duração dos dias vai além da medida de nosso mundo: as noites são claras e, em partes distantes da Britânia, curtas, tanto que há apenas um curto espaço de tempo entre o anoitecer e o amanhecer. Se não houver nuvens para impedir, o brilho do sol - dizem - é visível durante a noite: ele não se põe e então se levanta, mas siplesmente muda de lugar. Isso quer dizer que as extremidades planas da terra com suas sombras fracas não projetam a escuridão e o cair da noite nunca alcança o céu e as estrelas.

O solo, com exceção da oliveira, da videira e outros frutos típicos de terras mais quentes, é passivo de plantações e fecundo em gado: eles desenvolvemse lentamente, mas são rápidos para brotar - em cada caso pela mesma razão, a grande humidade do solo e do céu. A Britânia produz ouro, prata e outros metais, a conquista vale a pena. Seu mar também produz pérolas, mas de certa forma obscuras e cor-de-chumbo. Alguns acham que falta habilidade a esses pescadores de pérolas; no Mar Vermelho, nós imaginamos que elas são retiradas vivas e ainda respirando das ostras, enquanto na Britânia elas são recolhidas somente quando lançadas na praia: quanto a mim, eu acreditaria mais prontamente estar faltando qualidade às pérolas que cobiça aos romanos. 
13. Quanto ao povo mesmo, eles pagam eficazmente as cobranças, tributos e obrigações impostas pelo governo, se não houver abusos. Eles ficam rebeldes ante o incorreto: porque sua sujeição, embora plena o suficiente para envolver a obediência, não envolve a escravidão. O divino Júlio foi, de fato, o primeiro romano a entrar na Britânia com um exército.

A partir de então, o historiador passa a entrelaçar ao texto o tema da política militar romana.

A introdução de um texto etnográfico sobre a Britânia dentro da biografia de Agricola não causa estranheza, já que apresenta ao leitor as características da região para onde a figura principal do texto foi enviada e de seus habitantes. Caracteriza-se assim como uma ferramenta importante para a obra, pois por ela os leitores constroem uma imagem das condições com as quais se deparou e teve de enfrentar o general Agricola. No início do primeiro parágrafo dessa digressão (10), Tácito justifica a elaboração desse texto etnográfico:

A posição geográfica da Britânia e os povos que lá habitam têm sido registrados por muitos escritores: se eu trato deles não é pelo desafio da comparação em matéria de exatidão ou talento, mas porque foi Agricola quem os subjugou completamente: portanto, onde escritores mais antigos ornaram retoricamente um tema ainda legendário, será encontrada apenas uma confiável narração de fatos.

A apresentação da proposta do texto faz as vezes de proêmio, que normalmente abre textos de historiografia, ao qual se segue a delimitação territorial: “A Britânia é a maior ilha conhecida pelos romanos: com relação a sua extensão e posição, tem a Germânia a leste e a Espanha a oeste (...)”. Em Germania não há qualquer tipo de proêmio, parte-se da questão 
geográfica: "Toda a Germânia está separada dos gauleses retos e panônios pelos rios Reno e Danúbio (...)"

O texto sobre a Britânia não é construído apenas com base em escritos etnográficos anteriores. O material etnográfico disponível sobre a Britânia, que parte de Pitéas de Marselha (323 a. C.) e prossegue com escritores posteriores, serve de fonte, mas Tácito o altera pelas informações atuais recebidas da expedição de Agricola (MARINCOLA, 2007). Por exemplo: "Foi somente sob Agricola que frotas romanas pela primeira vez contornaram esta costa, a costa do mais remoto mar, e estabeleceram a insularidade da Britânia." Portanto, este historiador traz uma novidade e certamente digna de nota, pois "onde escritores mais antigos ornam retoricamente um tema ainda legendário, será encontrada apenas uma confiável narração de fatos".

Nessa digressão sobre os britanos em Agricola, notamos também o desenvolvimento de três topoi da escrita etnográfica (parágrafo 12), que também estão presentes em Germania: a climatologia, os produtos do solo e ouro, prata e outros metais. Seu desenvolvimento em ambas as obras se dá na mesma ordem, porém os dois primeiros topoi são mais trabalhados em Agricola (TRÜDINGER, 1918). A descrição da Britânia é, inclusive, mais abrangente que a da Germânia, segundo Trüdinger. Germania é atualmente vista pela maioria dos estudiosos como monografia etnográfica, entretanto, não desdobra essas questões tanto quanto faz a digressão etnográfica de Agricola, um indício provável de que o foco de Germania está na observação dos fatores que constituem a identidade dos germanos e os torna o povo inigualável que é, analisando principalmente sua vida social, da qual fazem parte os hábitos guerreiros, os costumes morais e da vida cotidiana.

Segundo Dench (MARINCOLA, 2007), a experimentação etnográfica, mais que a escrita meramente, torna-se realmente explícita no final da República, mesmo que este conceito esteja arraigado em algumas tradições antigas, como já percebemos em Heródoto, 
quem afirma ter ele próprio viajado e realizado pesquisa etnográfica, principalmente no caso do Egito. O principal exemplo de experimentação ligada à escrita é César. Em De Bello Gallico, conhecimento e conquista estão intimamente relacionados; o general exemplar do texto é quem escreve sobre as particularidades gaulesas em contraste com uma ameaça germânica mais monolítica. O exemplo do general Agricola também pode ser citado, apesar de o escritor ter sido seu genro.

Pelo que vimos de excursi etnográficos em escritos históricos, podemos perceber que, até a época de Tácito, este expediente historiográfico vinha sendo utilizado para tentar descrever completamente o povo inimigo em um contexto de guerra, portanto ligados à conquista. Germania, então, pode ser vista como integrante desta tradição etnográfica da forma como era desenvolvida, dadas as frequentes investidas de Roma contra os germanos, ou em chave irônica, já que os romanos não conquistaram de forma definitiva a Germânia, então, o que era para ser parte de uma obra de história passou a ser esta mesma o todo, pelo fato de Germania ser uma monografia, uma obra independente e não um excursus.

Por esse motivo, por Germania não ter um prefácio e por não haver notícia na literatura romana de outra monografia etnográfica, alguns estudiosos, como Paratore (1962), consideraram-na como um estudo preliminar para as Histórias, mas esta ideia não recebeu aceitação geral segundo Rives (TACITUS, 2002). Tal hipótese fundamenta-se na ideia de que seria muito mais provável que um texto etnográfico fosse, à época, uma digressão, um expediente recorrente em histórias a ser uma novidade. Porém, há uma antiga tradição de monografias etnográficas e Tácito pode estar se filiando, de certa forma, a esta. Além do mais, a apresentação dos germanos nas duas obras é marcadamente diferente, o livro IV das Histórias traz o relato da rebelião germânica, apresentando os germanos menos favoravelmente que em Germania. Syme (1958, p. 138) faz a seguinte afirmação a esse respeito: "Ver Germania, em qualquer sentido que seja, como uma introdução às Histórias de 
Tácito é precoce e errôneo (mesmo que seja vista como um excursus estendido e antecipado)”. Pois comenta Syme que em Germania não há menção a nenhum acampamento legionário de Vindonissa a Véteros e Noviomago e certamente não trata de acampamentos estranhos e tribos pequenas, o que prestaria um grande serviço às Histórias no relato da disputa ocorrida ao longo do Reno. Ascibúrgio, por exemplo, é mencionado em Germania (3.3) somente pela origem de seu nome fazer parte da lenda relatada e não como um forte como em Histórias (IV, 33). Em Histórias, Tácito demonstra um admirável conhecimento do nome dos lugares na região do Reno (SYME, 1958).

Um olhar rápido pelas obras de Tácito possibilita notar que este foi o historiador que utilizou mais espécies historiográficas e trabalhou-os de uma maneira como até então não havia sido feita, explorando a mistura de gêneros em uma trama bem arranjada e explorando os limites genéricos.

\section{I.3 Da estruturação da monografia etnográfica em Germania}

Pelo esquema montado por Thomas (2009) de acordo com os temas dos parágrafos, temos para a primeira metade de Germania: 1. situ e fronteiras; 2-4. origem, nome e características físicas dos germanos; 5. produção e minerais; 6-8. armas e características militares; 9-10. religião; 11-15. sistemas políticos; 16. habitação; 17. vestuário; 18-21. casamento e relacionamentos; 22-4. bebida e outros entretenimentos; 25 . uso de escravos; 26. hábitos de agricultura; 27.1-27.2. funerais. Pelo exposto, já podemos notar que a estrutura desta seção de Germania foi forjada no molde dos escritos etnográficos. 
Resumindo esta divisão de Thomas, temos seis temas gerais: território, origem e características físicas, costumes militares, religião, sistemas políticos e costumes sociais; em uma detalhada exposição sobre um único povo, o germano, e em uma única obra. Mas diferentemente das primeiras monografias, em que essas seções temáticas são separadas umas das outras e totalmente independentes, em Germania Tácito enlaça um tema a outro em uma trama bem arquitetada (THOMAS, 2009). De acordo com Perret (1949, p. 20), não foram apenas teorias e categorias que Tácito recebeu de seus predecessores etnógrafos, mas também esse estilo de composição literária segundo o qual as diversas partes da descrição se seguem, postas como em desordem, e frequentemente conectadas por simples ganchos verbais. A partir deste modelo, Tácito, de maneira muito particular, desenvolve o texto por associações verbais e enreda e leitor desde o princípio.

O parágrafo 5, por exemplo, trata dos minerais encontrados na terra germânica e o parágrafo 6, das armas, então a conexão é feita ao começar a falar de armas pelo minério utilizado em sua confecção. Tal relação fora, outrossim, exposta por Trüdinger (1918):

Também buscam mais a prata que o ouro, sem nenhuma afetação íntima, mas porque uma soma de denários de prata é mais fácil para adquirir mercadorias comuns e de baixo custo.

6. Na verdade, nem o ferro é abundante, como se pode inferir pelo tipo de suas armas. Raros são os que usam espadas ou lanças maiores:

Conexão semelhante, apenas em ordem inversa, faz Heródoto em Histórias I, 215 tratando dos masságetas: "Eles fazem toda sorte de coisas de bronze e ouro. Quando se trata de pontas de lança, de flechas e machadinhas, eles sempre usam bronze, mas decoram seus elmos, cintos e couraças com ouro. (...) Eles não usam ferro ou prata de forma alguma, nem sequer os possuem em seu país, todavia há bronze e ouro em abundância”. 
O que também podemos perceber pela leitura de Germania é que esta passagem de um tema a outro não ocorre somente no exato momento da mudança de um parágrafo a outro ou em apenas um período, mas no decorrer de um parágrafo, como no oitavo; fato que nos leva a pensar na separação do texto em parágrafos como uma divisão mais prática dos assuntos e não absoluta.

8. Contam as narrativas que algumas batalhas, já a ponto de perder-se, foram restabelecidas pelas mulheres, dada a constância de suas preces e a interposição de seus peitos, assim indicado de perto o cativeiro, o que eles temem mais arrebatadoramente com relação a suas mulheres, a ponto de serem mais eficazmente constrangidos os ânimos dos povos a quem se exige, dentre os reféns, garotas nobres. Ademais disso, julgam haver nas mulheres algo de sagrado e previdente e não desprezam seus conselhos nem negligenciam suas predições. Sob o império de Vespasiano, vimos Veleda ser considerada como uma divindade, durante muito tempo, pela maioria dos homens; e outrora veneraram também Aurínia e muitas outras, não com vil lisonja nem como se forjassem deusas.

Ao nos contar sobre as batalhas restabelecidas pelas mulheres por suas preces e do medo que os germanos têm de que façam suas mulheres reféns, Tácito mescla o tema da guerra com o das mulheres e o das mulheres com o da religião para chegar ao final do parágrafo tratando das deusas e iniciar o seguinte falando dos deuses germânicos. Portanto, dos hábitos bélicos à religião, que em uma monografia etnográfica tradicional representaria uma mudança repentina, em Germania é tão sutilmente arranjada, que a leitura flui sem quebras. De acordo com Rives, Tácito toma a elegância como princípio de organização do 
texto e deliberadamente evita agrupar toda a informação em um tópico, mas busca variedade e transições graciosas (TACITUS, 2002).

Outra transição de temas realizada com esse procedimento ocorre no interior do parágrafo 5, (TRÜDINGER, 1918): “Sua honra e glória certamente não derivam da aparência dos rebanhos: alegram-se com a quantidade, e estas são as únicas e mais agradáveis riquezas que possuem. Se foram deuses favoráveis ou encolerizados que lhes negaram o ouro e a prata, eu não saberia dizer”. Ao final do breve relato sobre o gado da Germânia, Tácito se refere a esses animais utilizando a palavra opes, cujo significado remete à riqueza monetária ou material. Dessa forma, o leitor já é introduzido à ideia antes mesmo do tema dos metais valiosos e demais ser de fato apresentado, portanto, essa passagem ocorre de modo sutil e natural a quem lê.

Também Diodoro já havia criado ligações temáticas ao longo de suas descrições de povos. Em Biblioteca Histórica V, 25-26, por exemplo, Diodoro, depois de tratar do clima frio que acomete os gauleses, passa à produtividade do solo, que devido à temperatura, não produz vinho. Em Germania, parágrafo 5, também se passa do clima ao solo, porém, sem uma conexão entre esses temas. Para Norden (1920, p. 462), a semelhança do princípio de composição entre Diodoro e Tácito é óbvia, e para ele a ausência de elos temáticos é típica sim em etnografias, mas nas que são significativamente mais antigas. Portanto, poderíamos pensar neste elemento como um expediente emulado por Tácito de etnógrafos anteriores.

Todavia, a construção de elos temáticos por associação de ideias é muito mais trabalhada em Posidônio e Tácito (NORDEN, 1920, p. 465) que em outros autores, os quais fazem uso mais pontual e esporádico deste recurso.

A etnografia enquanto composição literária desenvolveu também uma linguagem particular. Os fragmentos existentes de Hecateu mostram um estilo direto e sem deleite, de alto rigor descritivo. A seriedade e a gravidade dos textos etnográficos ainda estão presentes 
em Heródoto, mas ele consegue, segundo Norden (1920, p. 460), combinar a forma puramente científica com o discurso $\gamma \lambda v \kappa \imath \imath \eta ́ \varsigma$ jônico. As características formais dos textos etnográficos primeiros, como as frases curtas e simples, tornam-se preceptivas para os escritos daqueles que se propõem a tratar do mesmo tópico, a saber, descrição de povos e lugares que habitam, pois replicam o estilo narrativo primitivo. Posidônio se vale destas particularidades ao tratar dos hábitos alimentares dos celtas, por exemplo, como podemos perceber pelo longo fragmento de suas Histórias citado por Ateneu em Deipnosofistas, IV, 151-152, do qual citamos apenas o início:

Os celtas colocam palha no chão quando eles servem refeições, que eles fazem em mesas de madeira montadas a pouca distância do chão. Sua comida consiste de poucos pães, mas uma grande quantidade de carne preparada em água ou assadas sobre carvão ou em espetos.

Para Perret, a característica formal dos textos dos primeiros etnógrafos constitui-se posteriormente em lei dessa espécie literária (TACITE, 1949). Tácito segue-na e assim dá a sua narração um ar de espontaneidade, como a de um viajante ingênuo que também se ocupa da reflexão científica, ao mesmo tempo em que cose brilhantemente os temas uns aos outros e os conclui com fórmulas impactantes, as sententiae.

Na primeira parte deste capítulo, apresentamos o topos etnográfico da reflexão sobre a origem de um povo (p. 60 e 61) e agora veremos mais detalhadamente sua utilização em Germania. Esse topos é introduzido no parágrafo 2: “Quanto aos próprios Germanos, eu os julgaria nativos e de forma alguma imiscuídos aos que vêm de outras gentes”. A hipótese de Tácito sobre a formação dessa gens é aí demonstrada, seguida pelos motivos que a sustentam: os povos desejosos de outro local para moradia de outrora lá chegavam em naus e não por terra; poucos navios do orbe nostro visitam o imenso e adverso Oceano e ninguém, exceto os 
nativos da Germânia, deixaria a Ásia, a África ou a Itália, enfrentaria o perigo do violento e desconhecido mar, para dirigir-se à Germânia, de aspecto tosco, clima rigoroso e desagradável. Ainda no mesmo parágrafo, Tácito relata a tradição germânica originada com o deus Tuistão, deum terra editum, que é relembrada pelos nativos por meio de cantos antigos e explica a adoção do nome "Germânia". Primeiramente, o autor não faz nenhuma menção a outras hipóteses para a origem dos germanos além da autoctonia, nem mesmo as cogita, diferentemente do que podemos verificar no caso dos britanos no parágrafo 11 de Agricola, (trazido por nós na página 72 deste trabalho) e no caso dos judeus em Histórias, V, 2-3, de Tácito.

Apesar disso, nos dois primeiros argumentos para a autoctonia há espaço para considerarmos não só possível como factível a migração, somente por mar, para terras germânicas, corroborada pelo fato de Hércules e Ulisses terem por lá passado (parágrafo 3), mas o terceiro argumento e o relato que se segue a esse vêm para invalidar qualquer teoria sobre o voluntário deslocamento de alguém, de qualquer parte do mundo conhecido, para tais rincões e o estabelecimento de moradia de quem tivesse por lá aportado, confirmando a hipótese de Tácito.

No parágrafo 4, o autor volta a sua teoria para reforçá-la pela peculiaridade e especificidade dos germanos: "Eu próprio concordo com aqueles que julgam que os povos da Germânia não se mesclaram, por meio do casamento, com outras nações, dada a peculiaridade, pureza e tamanha similaridade de sua gente”. Trüdinger (1918, p. 149-151) chama a atenção para esse fato, assim como para a possibilidade de migração proveniente do sul indicada pela presença de Hércules e Ulisses na Germânia, e afirma que verificando a história do movimento das nações no passado, a existência de povos puros parece quase inacreditável. 
O próprio Tácito se contradiz (quia nec terra olim sed classibus advehebantur qui mutare sedes quaerebant) quando aborda a migração de povos gauleses para a Germânia no parágrafo 28. Após contar ao leitor ter lido em César que a posição dos gauleses anteriormente era mais forte, afirma que certamente por isso era crível que os gauleses tivessem passado para a Germânia e questiona: "E quanto um rio opunha-se a que cada povo que se fortalecera ocupasse e trocasse de sítio, até então públicos e não divididos pelo poder dos reinos?". Por esta passagem somos informados que povos mais fortes de antes tinham facilidade em estabelecer-se em território germano, uma informação que faria muita diferença naquela trama sobre a autoctonia em que Tácito procurou enredar o leitor nos primeiros parágrafos da obra. Para além de um descompasso no texto, percebemos que o autor quer conduzir seus leitores por determinadas sendas, para que cheguem às conclusões que ele, o autor, deseja. Neste caso, ele quer nos convencer da autoctonia do povo germano, um elemento que colabora para a construção da imagem dos germanos como povo único, só parecido a si mesmo. Essa visão não só justificaria Germania, um estudo sobre os costumes sociais dos nativos dessa região, como também o impasse histórico imposto por eles à expansão do império romano. Isso, contudo, não exclui a possibilidade de Tácito ter outros objetivos com a obra (ver capítulo III. 1).

Segue-se à afirmação sobre a pureza racial a descrição física dos germanos (parágrafo 4): "olhos azuis e ameaçadores, cabelos ruivos, corpanzis vigorosos somente ao embate". Esses poucos detalhes físicos estão presentes, segundo Tácito, em todos os habitantes da Germânia, indicando assim sua homogeneidade, mas como nos alerta Trüdinger (1918) esse não é um critério importante na definição da origem da gente, como em Agricola, 11 (ver p. 72). Percebemos que a descrição inicia-se com truces "ameaçadores", um dos dois adjetivos para oculi, opção de Tácito que associa a característica guerreira à natureza de todos os membros dessa gens; e encerra-se com et tantum ad impetum valida, indicando que seus 
corpanzis são vigorosos apenas para a luta, uma predisposição natural à guerra, pois não suportam o trabalho com a mesma firmeza, e é exatamente nesse ponto que há a ligação entre a resistência dos germanos com a teoria sobre a interferência das condições climáticas e geográficas na constituição de características específicas. Como não habitam uma região quente, não toleram a sede e o calor intenso, mas acostumaram-se ao frio e à fome graças ao clima e ao terreno, e deste tópico, cuja ligação é justamente caelo solove, Tácito passa a tratar de questões geográficas e climáticas do local no parágrafo 5, introduzido por terra. Retomamos aqui então um assunto que discutimos mais acima, o procedimento de criação de elos temáticos no texto, que faz com que os temas se sigam uns aos outros de modo fluido e sem quebras.

Trüdinger (1918) chama-nos a atenção para a justaposição do tópico da resistência física com o da geografia e como a construção literal desse primeiro tópico assemelha-se em peças etnográficas, construção típica da escrita etnográfica e que indicaria a inserção de determinada obra nessa tradição. Em Histórias Filípicas de Pompeu Trogo "corpora ad inediam laboremque, animi ad mortem parati” segue-se à explicação geográfica e climática da Hispânia, e a salubridade própria do clima já prepara o leitor para a resistência física de seus habitantes, em De Bellum Iugurthinum, XVII, de Salústio, "genus hominum salubri corpore, velox, patiens laborum" está entre a questão geográfica e a climática, mas sem qualquer elo entre eles, e em Historiae, V, 6, de Tácito, “corpora hominum salubria, et ferentia laborum" está também entre esses dois tópicos e sem qualquer elo ou relação explícita entre eles. A diferença em Germania é a utilização desse expediente de composição literária adotado amiúde por Tácito ao longo dessa obra, que cose um tema a outro, consequentemente estabelecendo uma relação entre os temas.

Pelo curto espaço reservado à geografia, percebemos que Tácito não pretende detalhar as características do território de maneira científica; a língua do povo germano também não é 
uma preocupação desse historiador, pois apenas temos notícia de dois vocábulos: framea, no parágrafo 6 e glesum, no parágrafo 45. Trüdinger (1918) afirma que a natureza do Tácito etnógrafo se destaca mais se comparada com o maior dentre os etnógrafos gregos: Posidônio. De acordo com Trüdinger, o interesse de Posidônio é universal e científico, para ele, todas as pessoas são partes iguais do Todo; Posidônio aprofunda a análise sobre a organização política e vida social dos povos que observa, trata dos detalhes dos alimentos e sua preparação, das características do comer e beber, de costumes estranhos, como os duelos durante o banquete e o tratamento dado a inimigos mortos. Já Tácito acaba apresentando as condições políticas reais dos germanos a partir da descrição, em linhas gerais, da vida social desse povo: seus hábitos de guerra, morais, familiares, entre outros. Ou seja, de uma descrição que aparenta ser despretensiosa, Tácito delineia a essência germânica, o que faz os germanos serem o que são, apresentando suas bases.

Posidônio faz uma descrição clara e pictórica, tanto que é possível ver o cenário todo diante dos olhos. Quanto à habitação, Posidônio apresenta ao leitor claramente a forma, tamanho e material utilizado, enquanto Tácito não informa qual seja exatamente o material usado na construção das casas, nem detalhes de sua forma: a avaliação é estética (parágrafo 16). Trüdinger (1918) diz, por exemplo, ser inesquecível a representação de Posidônio do sacrifício feito pelos sacerdotes celtas, com todos os detalhes da aparência das sacerdotisas, o tamanho da caldeira e do processo de oferta do sacrifício; e afirma que certamente há momentos em Germania em que a clareza é alcançada, mas quase sempre se funde com efeitos retóricos.

Ainda na visão apresentada por Trüdinger (1918), Tácito, com uma formulação concisa e um estilo que projeta luz e sombra, criando antíteses espirituosas, quer agir na mente do leitor, já Posidônio é o espelho que reflete o mundo exterior, claro e nítido em seus 
contornos e cores, entretanto distante da objetividade dos antigos etnógrafos, pela construção de enargeias.

\section{I.4 Comparações entre romanos e germanos}

Ao longo de toda a obra, pudemos identificar apenas quatro passagens em que Tácito explicitamente faz comparação entre germanos e romanos. Há outras comparações no decorrer do texto, todas são genéricas e o segundo termo da comparação pode referir-se a quaisquer povos, mas é muito provável que o leitor julgue estar diante de um vitupério aos costumes romanos, posto que tais atitudes depreciativas eram vigentes em Roma à época de Tácito e que o ponto de vista do autor não escapa a sua posição no espaço e no tempo.

As comparações sutilmente tendem a favorecer os germanos, cujos costumes são melhores geralmente em decorrência de sua origem primitiva. Mas como vimos na primeira sessão desses comentários (p. 62), o louvor e idealização do estado natural, que inevitavelmente critica a ostentação e hábitos desregrados e corruptos da vida em grandes cidades como Roma, é uma das teorias e preceptivas de textos etnográficos.

Também é um traço típico de peças etnográficas gregas a descrição de um outro povo com base em seu próprio como uma maneira de o escritor melhor se fazer entender pelos seus leitores. Mas nem sempre esta oposição era feita de forma neutra. Na História de Diodoro, supracitada, percebemos que as comparações estabelecidas entre gregos e egípcios, curiosamente, buscam o enaltecimento destes últimos; sobre a última seção, destinada aos costumes e modos dos egípcios, Fraser diz: 
Esta seção, a mais significante para nossa avaliação de Hecateu, mostra inegavelmente que uma proposta do trabalho era contrastar as duas culturas, grega e egípcia, em detrimento da primeira.

Portanto, ainda que o povo romano fosse nomeado como o segundo membro desta comparação, estes trechos poderiam ser entendidos como se referindo a este elemento constituinte da tradição etnográfica.

As comparações explícitas são as seguintes:

6. (...) equi (...) sed nec variare gyros in morem mostrum docentur: in rectum aut uno flexu dextros agunt, ita coniuncto orbe ut nemo posterior sit. Os cavalos (...) não são adestrados a dar voltas para todos os lados como é hábito nosso: seguem em linha reta ou com uma curva à direita, de tal forma que, fechado o círculo, ninguém fique para trás.

11. (...) nec dierum numerum, ut nos, sed noctium computant.

Não contam, como nós, o número de dias, mas sim de noites.

16. vicos locant non in nostrum morem conexis et cohaerentibus aedificiis: suam quisque domum spatio circumdat, sive adversus casus ignis remedium sive inscrita aedificandi.

Estabelecem povoados não com edificações contíguas e conjugadas, segundo é nosso costume, mas cada qual circunda sua casa com um espaço, como prevenção contra incêndio ou por falta de habilidade de construir.

25. Ceteris servis non in nostrum morem, descriptis per familiam ministeriis, utuntur: suam quisque sedem, suos penates regit. 
Possuem escravos, que não são, como é nosso costume, designados para serviços domésticos. Cada um governa sua casa e moradia.

Contudo, são as comparações genéricas as mais incisivas. Como exemplo citamos duas passagens do parágrafo 19: Nemo illic vitia ridet (Lá ninguém ri dos vícios) e (...) ibi boni mores valent quam alibi bona leges (e bons costumes ali valem mais que boas leis em outro lugar). Outros trechos há que, ainda que não sejam comparações, mostram que o contato com os romanos lhes ensina hábitos do centro urbano que podem ser prejudiciais à manutenção dos bons costumes provindos da simplicidade primitiva tão digna de louvor, fazendo dos romanos os "vilões corruptores", como se pode perceber no parágrafo 5, onde Tácito diz que as nações mais próximas à fronteira, pelo hábito do comércio, vendem o ouro e a prata por um bom preço, conhecem o dinheiro romano (nostrae pecuniae agnoscunt) e escolhem, enquanto as pessoas que habitam as regiões mais distantes usam o modo mais simples e tradicional de permuta de mercadorias; e também no parágrafo 15 , em que há a afirmação de que os romanos já os ensinaram a aceitar dinheiro (iam et pecuniam accipere docuimus).

Pelo exposto, não é possível afirmar categoricamente que o objetivo de Tácito tenha sido o de criticar os romanos em favor dos germanos pela comparação entre ambos os povos, pois ele não fornece base para esse tipo de constatação. Como afirma Rives (TACITUS, 2002, p. 51): “Tácito não opõe simplesmente morais germani a imorais romanos, já que ele critica seu modo de viver pelo menos tanto quanto o louva". E certamente podemos coletar em Germania passagens que trazem uma crítica de seu autor a respeito dos costumes do povo estudado. No parágrafo 11 temos:

illud ex libertate vitium, quod non simul nec ut iussi conveniunt, sed et alter et tertius dies cunctatione coeuntium absumitur. 
É um vício derivado de sua liberdade não se encontrarem ao mesmo tempo, como se convocados, e assim um dia a mais, e ainda um terceiro, é consumido pela delonga dos participantes.

No parágrafo 15, Tácito diz que quando os germanos não vão para a guerra, eles se dedicam muito às caçadas, porém vivem mais na ociosidade, entregues ao sono e à comida, enquanto o cuidado da casa, dos penates e dos campos fica a cargo das mulheres, dos velhos e dos mais incapazes da família, mostrando assim um traço de seu caráter que, de fato, pode ser encarado como um vício.

Mesmo assim, Germania apresenta muito material que não tem relação com questões morais e não pode ser explicado simplesmente como suplemento, conforme aponta Rives (TACITUS, 2002).

Mas devemos lembrar que apesar de ser possível ler Germania como um elogio aos germanos e um vitupério aos romanos, podemos também vê-la como uma obra que defende a teoria da excelência do estado primitivo ou como uma obra que se supõe defensora dessa teoria apenas para poder criticar os romanos, enfim, muitas outras hipóteses que já foram levantadas e defendidas por estudiosos são factíveis e serão tratadas na terceira parte destes comentários. 
Capítulo II. Sobre a construção da periegese em Germania

\section{1 Das características}

Em 27, 2 de Germania inicia-se o catálogo das nações germanas com o seguinte parágrafo servindo-lhe de abertura:

nunc singularum gentium instituta ritusque, quatenus differant, quae<que> nationes e Germania in Gallias commigraverint, expediam.

Agora apresentarei os ritos e as convenções de cada povo, até que ponto diferem entre si, e quais nações migraram da Germânia para as Gálias.

Segundo Thomas (2009), este princípio tem um forte tom didático, cuja estrutura nunc + objeto direto ou subordinada substantiva objetiva direta + expediam é uma técnica apropriada a inícios didáticos e encontrada em Varrão (De lingua latina $\mathrm{V}$, 1, 7: nunc singulorum verborum origines expediam) antes de tratar da etimologia de cada palavra. Mas esta estrutura é muito recorrente em poesia, primeiro em De rerum natura de Lucrécio (2.626; 4.633-4; 6.239-45, 495-7, 639-41, 680-2, 738-9, 1090-3) e depois em Geórgicas e Eneida de Virgílio (G. 4.149-50; En. 6.756-9; 7. 37-40; 11. 314-15). Citamos como exemplos dois trechos de Eneida e um trecho de Geórgicas com o intuito de apresentar o modelo de estrutura imitada por Tácito e seu contexto de utilização; Eneida VI, 756-9, introduz um desfile de líderes italianos e romanos: nunc age, Dardaniam prolem quae deinde sequatur | gloria, qui maneant Itala de gente nepotes, | inlustris animas nostrumque in nomen ituras | expediam dictis et te tua fata docebo; Eneida VII, 37-40 vem no início de um livro que será concluído com um catálogo de tribos da Itália: nunc age, qui reges, Erato, quae tempora, 
rerum | quis Latio antiquo fuerit status, aduena classem | cum primum Ausoniis exercitus appulit oris, | expediam; e Geórgicas IV, 149-50 inicia um catálogo sobre as qualidades das abelhas: nunc age, naturas apibus quas Iuppiter ipse | addidit expediam.

A introdução da segunda metade de Germania feita desta maneira, seguindo uma tradição muito presente na épica para dar início aos catálogos, sugere ao leitor o conteúdo que se seguirá. E Tácito empregará novamente este expediente em Anais, IV, I. 1, para inserir uma digressão sobre uma vida:

nunc originem, mores et quo facinore dominationem raptum ierit, expediam Agora apresentarei sua origem, seus costumes e por qual crime ele tomaria para si o poder absoluto.

E também em Histórias, I, LI. 1:

nunc initia causasque motu Vitelliani expediam

Agora apresentarei o início e as causas do motim de Vitélio

A organização dessa segunda metade de Germania é muito diferente da primeira. Aqui Tácito segue as convenções da tradição periegética ao conduzir o leitor a um "tour" pela Germânia, para o qual Rives chama a atenção (TACITUS, 2002). Uma natio segue-se a outra ligada brevemente com a anterior e essa passagem ocorre quando já foram feitos comentários sobre uma determinada natio e tratar-se-á da seguinte, que é aquela cuja localização é a mais próxima à vista anteriormente. Como notamos, por exemplo, no início de Germania, 30 "Para além destes povos, os catos começam seu assentamento (...)” e 32 “Os usípios e os tencteros habitam próximo aos catos, às margens do Reno, cujo leito já basta como fronteira”. 
Em contraste com a generalização da primeira metade, conclui Rives, a segunda metade de Germania está completamente voltada para as particularidades (TACITUS, 2002). Tácito afirma que pretende apresentar "os ritos e as convenções de cada povo, até que ponto diferem entre si”, entretanto, as diferenças entre eles não são muitas. Ficamos sabendo, portanto, que: os catos deixam o cabelo e a barba crescerem assim que se tornam rapazes e só os cortam quando matam um inimigo e essa prática é empregada poucas vezes por outras populações dos germanos (parágrafo 30); a infantaria dos catos é tão excelente quanto a cavalaria dos tencteros (parágrafo 32); os reudignos, os aviões, os anglos, os varinos, os eudoses, os suardones e os nuítones, têm em comum o culto à deusa Nerto, a mãe terra (parágrafo 40) e os hábitos dos estios são um tanto quanto peculiares a esse povo. E em muitos parágrafos, como no 33, 34 e 37, Tácito não tem quase nada a dizer sobre as tribos em questão e as poucas informações não dizem respeito ao proposto por ele mesmo na introdução dessa seção. Concordamos com Rives (TACITUS, 2002) então quando afirma que Tácito “cria a impressão que as diferenças entre as várias tribos germânicas são insignificantes em comparação com sua natureza comum, e que a segunda parte é essencialmente uma lista de todas as tribos da Germânia”. E Rives, usando uma genealogia moderna, ainda acrescenta que o que Tácito faz de fato é descrever uma gente e então listar suas espécies, assim ele complementa sua descrição do caráter dos germanos com uma demonstração de seu número e extensão. Essa explicação torna a periegese de Germania apenas um catálogo acessório, mas para os estudiosos cuja interpretação sobre a finalidade do texto recai em sua função de manual de guerra, a primeira parte é o complemento, uma contextualização geral sobre a vida social dos germanos e o ponto central seria o mapa explicativo de nationes que Tácito desenha a seguir. 
Pela leitura dessa segunda metade de Germania pudemos notar que a preocupação maior se concentra na localização das nationes germanas e em questões de guerra, como suas batalhas e consequências e hábitos guerreiros.

\section{2 Digressões históricas em Germania}

Em Roma, a construção de textos etnográficos destinava-se a compor obras de história, como digressões, e essa tradição já remontava a historiadores gregos. Com Germania, Tácito "quebra" essa tradição ao retomar a forma de composição utilizada originalmente para etnografias e inverte os papéis usuais de história e etnografia, a monografia é etnográfica e a história é digressão.

A primeira digressão histórica em Germania é construída no parágrafo 33, por meio da qual se introduz no material etnográfico acontecimentos históricos envolvendo nationes germanas e sua relação com o Império romano. Tácito parece aludir ao fato da destruição dos brúteros e sua expulsão por nações vizinhas para tratar de Roma e dos limites do império (THOMAS, 2009); após mencionar o ocorrido, o historiador faz uma reflexão sobre a causa: “seja pela aversão a sua soberba, seja pelo atrativo dos despojos, seja por um certo favorecimento dos deuses para conosco, porque certamente não invejam a visão da batalha". Mas, na verdade, o motivo não importa, o que interessa é que mais de sessenta mil germanos, ou seja, inimigos, morreram sem qualquer esforço da parte dos romanos, apenas para o deleite de seus olhos, e isso deve ser de fato magnífico, independente da situação na qual se encontrasse o Império romano. 
No caso, os germanos impunham há tempos um árduo obstáculo à expansão territorial romana e a ruína de uma parte desse tão potente adversário pelo mesmo adversário parece providencial e Tácito, como em prece aos deuses, diz, por nossa versão, “eu rogo que esta situação permaneça e se prolongue entre os povos, se não por amizade a nós, seguramente por ódio a eles”, pois onde a aliança com outros povos não prevalecer, que reine a discórdia entre eles, o que levou à destruição dos brúteros; no entanto, a oração a seguir, o ablativo absoluto urgentibus imperii fatis (quando os destinos do Império o ameaçam) parece indicar a iminência do declínio do Império, quer pela ameaça inimiga quer por guerras civis, mas como aponta Thomas (2009) é uma tendência universal da mentalidade literária romana ver o declínio e a deterioração como forças naturais. Esse período em Germania retoma uma construção utilizada por Tito Lívio em Ab Urbe Condita V, 22, 8 (postremo iam fato quoque urgente) ao relatar a queda dos veios e o declínio do mundo etrusco após todos seus anos de grandeza e riqueza, e também para se referir às grandes derrotas militares romanas em Ália em V, 36, 6 (iam urgentibus Romanam urbem fatis) e em Canas em XXII, 43, 9, por Virgílio em Eneida XI, 587 (quandoquidem fatis urgetur acerbis) ao falar sobre a morte de Camila e II, 653, e por Lucano X, 30. Em todas essas passagens, exceto em Lucano, o destino apresenta-se como um iminente desastre. Rives mostra-nos, entretanto, que apesar de esta interpretação negativa ter muitos pontos a favor, é questionável (TACITUS, 2002); primeiramente porque mesmo que os germanos fossem considerados poderosos, como Tácito os apresenta no parágrafo 37, eles não eram infalíveis, pelo que também nos informa o autor na referida passagem. Eles são frágeis pela mesma característica que os torna grandes: sua liberdade; em 37.3 é a liberdade dos germanos, mais dura que a soberania de Arsace, o que ensinou aos romanos mais lições que antigos fortes inimigos, no entanto, essa liberdade, excessiva e carente de disciplina, com exceção dos catos (parágrafo 30.2), os torna vulneráveis às disciplinadas tropas de Roma. 
Mas refletindo sobre o parágrafo 33, nós percebemos que ainda que Tácito não tenha afirmado a inefabilidade germana e tenha apontado uma fraqueza guerreira desse adversário, proveitosa a triunfos romanos, uma das nationes, a dos catos, está livre dela e não é possível afirmar a crença do historiador na vitória, e conseqüente conquista, romana. A maneira como a descrição é conduzida enfatiza a força bélica germânica contra a romana, acrescendo-se a isso as vantagens que os próprios romanos fornecem a esses adversários ao se fragilizarem pela discórdia interna e guerras civis: "até que por ocasião de nossa discórdia e dos confrontos tomaram de assalto os quartéis de inverno das legiões". Essa descrição parte do ponto "Já os germanos", com o que se vai dizer ser esse o povo que apresenta perigo, pois diferentemente do oriente, que "além da morte de Crasso" nada mais significativo poderia empreender “depois de este mesmo ter perdido Pácoro e ter sido subjugado por Ventídio", os germanos “tendo derrubado ou aprisionado Carbão, Cássio, Aurélio Escauro, Servílio Cepião e Máximo Málio", uma considerável lista de comandantes, "tiraram cinco exércitos consulares do povo romano de uma só vez e destruíram ainda Varo e com ele três legiões de César", feito incrível aos olhos do leitor; e quando Tácito relata a contrapartida, os sucessos dos romanos sobre os germanos, as vitórias são poucas, sem qualquer detalhe sobre as perdas do inimigo e todas tiveram conseqüências desfavoráveis para o vencedor "Não foi impunemente que C. Mário os derrotou na Itália, o divino Júlio nas Gálias e Druso, Nero e Germânico em sua própria casa” e, além do mais, “A grande ameaça de Caio César logo transformou-se em zombaria”.

O segundo ponto trazido por Rives a se opor a essa interpretação negativa é o de que o pessimismo de Tácito não era constante nem total, sendo muito mais patente em Anais que em suas primeiras obras (TACITUS, 2002), hipótese cuja procedência exemplifica-se com o otimismo disseminado em Agricola sobre as benesses aguardadas no governo de Trajano:

Trajano está aumentando, diariamente, a felicidade desta época; e a confiança pública aprendeu não somente a ter esperança e orar, mas a 
receber a certeza da concretização de suas preces e assim fortaleceu-se (parágrafo 3).

Mas a ele (Agricola) não fora permitido sobreviver até a luz desta época ditosa e ver Trajano governar - uma consumação daquilo que ele anteviu em nossa audiência assim como em prece e profecia (parágrafo 44).

E seria pouco provável que um ano depois, ao escrever Germania, Tácito tivesse perdido toda a fé na força militar romana. Todavia, como o próprio autor de Agricola afirma no parágrafo 3 dessa obra "mas assim como é verdade que é próprio da natureza da fraqueza humana a cura operar mais lentamente que a doença e o corpo demorar a crescer e decair rapidamente, também é mais fácil aplacar o espírito dos homens e seu entusiasmo a revivêlos". A reanimação é um processo lento e diante de tão forte inimigo como os germanos e da fraqueza do Império, ocasionada por esse mesmo em virtude de guerras civis, o destino próximo dos romanos é preocupante.

E, por último, há o argumento de que o contexto em que se insere tal oração não favorece uma leitura negativa, já que Tácito apresenta a destruição dos brúteros positivamente, como um presente dos deuses, e dentro dessa visão seria pouco plausível que a sequência não fosse positiva. Esse argumento é utilizado por Benario (1968).

Nós não pensamos que a sequência ao relato da derrota dos brúteros por tribos vizinhas, seguida por um pedido (esperança) do autor para que esse fato sempre se repetisse entre povos inimigos, devesse ser obrigatoriamente positiva ou otimista; pois, como acreditamos que seja, esse fato histórico apenas foi trazido à baila por Tácito a fim de demonstrar a preocupação diante do destino do Império frente às complicações impostas pelos germanos e pelos próprios romanos, para quem a Fortuna não poderia oferecer nada melhor que a discórdia entre os inimigos naquele momento e, portanto, tal discórdia é comemorada e 
desejada, algo positivo que vem, e se anseia que venha, somente por existir alguma preocupação a que remediar. Outrossim, é possível, e provável, que essa preocupação aparente de Tácito tenha um caráter irônico. Syme volta sua interpretação para esse aspecto em 1936 (In: BENARIO, 1968, p. 39): “é talvez permitido ler, não tanto como uma preocupação com o destino futuro do Império e esperança que os inimigos de Roma estejam sempre divididos, mas como ironia e indignação por tal política dever ser recomendada no momento".

Benario (1968) apresenta um resumo dos pontos de vista que marcaram o intenso debate de estudiosos sobre essa questão e afirma, logo no início, que não acredita que Tácito estivesse pessimisticamente adiantando a queda de Roma. A discussão centra-se no entendimento do período urgentibus imperii fatis dentro do parágrafo 33 de Germania e Benario diz que sua interpretação é influenciada pela ideia comum de que o pessimismo é uma constante na obra desse historiador latino. O primeiro estudioso a se posicionar sobre esse tópico é Reitzenstein em 1914, quem expõe uma visão totalmente positiva sobre a leitura da passagem. Para ele, o momento da composição de Germania era favorável, já que o Império, pela primeira vez desde César, estava renovado sob o comando do general Trajano; a virtus romana e o fatum imperii Romani eram incontroláveis e esse fatum iria dominar os germanos, justamente porque ele conduzia Roma adiante, e o ódio dos germanos entre si naquele momento seria particularmente valioso. Pensamos que se a crença na inefabilidade da capacidade de conquista do Império estivesse na mente Tácito, não haveria necessidade de se desejar, de modo tão urgente e apelativo, que os inimigos matassem uns aos outros, Roma se valeria a si própria e não teria absolutamente nada a temer, nem os germanos; e algo melhor a Fortuna poderia sim conceder aos romanos que não a discórdia entre o povo inimigo que resiste à conquista a duzentos e dez anos, sua conquista. 
Andresen refutou essa interpretação de Reitzenstein, segundo Benario (1968, p. 38), focado em uma pequena parcela da extensa contribuição desse estudioso, e voltou-se ao sentido oposto da leitura do período em questão, a de que ali Tácito demonstra seu medo de que a máquina do estado possa não resistir à pressão de um povo como os germanos, visão com a qual estamos de acordo.

A seguir, em 1928, R. Heinze também rejeita a interpretação otimista de Reitzenstein e insiste que Tácito teme o momento em que os bárbaros, unindo suas forças, atacarão o Império. Quanto a essa interpretação, não vemos no tex to de Germania abertura para embasar tal conjectura.

Sabemos, também por Benario (1968, p. 41), que em sua ampla obra intitulada Tacito, E. Paratore posiciona-se a favor da visão pessimista; estamos de acordo com Paratore ainda por sua ideia de que o final do parágrafo 33 é a chave para a obra inteira, pois, de fato, a interpretação deste trecho não pode estar em desacordo com a interpretação da obra. Mas essa leitura pessimista está fundamentada também na construção da historiografia romana segundo V. Pöschl ${ }^{23}$, cuja concepção de historiografia baseia-se em três elementos: o fato de que as causas morais são responsáveis pela grandeza e declínio político, o surpreendente pessimismo sobre o destino de Roma e o sentimento de responsabilidade e culpa presentes naqueles romanos que se preocupam com a história de seu povo. Concepção da historiografia romana que se opõe àquela que defende a crença geral na imortalidade de Roma.

Por haver Tácito utilizado uma construção com recorrente sentido sombrio na literatura, principalmente por Tito Lívio, cujo relato era bem conhecido a Tácito e a seu público, segundo Rives, estaria o autor de Germania estabelecendo uma relação com a tradição literária (TACITUS, 2002). Pelas reflexões feitas acima, concluímos que essa relação não é de contradição, e sim de proximidade, já que Tácito imprime à passagem uma

\footnotetext{
${ }^{23}$ Cf. BENARIO, 1968, p. 42
} 
significação na mesma linha de seu uso freqüente, mas não diríamos negativa simplesmente, pois o historiador mostra preocupar-se com a situação delicada em que o Império se encontra, e isso serve de alerta ao leitor. Ademais, retomar a derrota em Ália retratada por Tito Lívio, por exemplo, implica lembrar que, embora traçada pelo destino, a causa desse evento reside realmente nas falhas morais romanas, como sugere Rives, ou seja, o destino dos romanos reflete suas virtudes e falhas (TACITUS, 2002).

Não discutiremos aqui a propriedade da leitura deste trecho latino urgentibus imperii fatis, que é uma emenda proposta por Beato Renano, enquanto os manuscritos dividem-se em urgentibus iam, in urgentibus e in gentibus, como informa Rives (TACITUS, 2002). Assim como a maioria dos comentadores, consideramos a passagem um ablativo absoluto e não um objeto indireto do verbo praestare, uma opção que condiz com a tradição literária e também está mais de acordo com a prática taciteana, como nos lembra Rives, verificada em Histórias I, 22, 1 urgentibus etiam mathematicis e Anais VI, 4, 3 Urgente Agrippa e XIII, 15, 3 Urgentibusque Agripinnae minis (TACITUS, 2002).

Como o parágrafo 33, o parágrafo 37 de Germania também constitui uma digressão histórica. O trecho de 37.2 sescentesimum et quadragesimum annum urbs nostra agebat cum primum Cimbrorum audita sunt arma Caecilio Metello AC Papirio Carbone consulibus lembra, segundo Thomas (2009), o Prefácio, 4 de Ab Urbe Condita de Tito Lívio supra septingentesimum annum em que o autor expressa sua intenção de traçar a história romana desde seu início, a qual remonta para além do ano 700. Pensamos que Tácito inicia desta forma esse período para, retomando a ideia expressa no texto de Lívio, apresentar toda a complexa relação de Roma com os germanos a partir do primeiro contato entre eles, relato que se refere a um período de duzentos e dez anos encapsulado em uma digressão de 167 palavras. Thomas (2009) nos chama a atenção para a resistência de Tácito ao prosaico por 
haver ele incluído o marcador de ano consular Caecilio Metello ac Papirio Carbone consulibus no final da sentença, quando esse normalmente inicia o período.

Germania 37.3, já discutido acima (p. 94), mostra que libertas, o ideal romano de outrora, representa enorme ameaça quando em posse do adversário. É essa libertas que faz o povo germano ser superior a todos os outros inimigos de Roma. E para Thomas (2009), a digressão histórica construída no parárafo 37 encerra-se com um epigrama que captura a postura ineficaz de Domiciano em 83 "nos últimos tempos tivemos mais triunfos que vitórias sobre eles". 


\section{Capítulo III. A Germania como um todo}

\section{1 Interpretações sobre sua finalidade}

Variadas hipóteses são feitas por estudiosos de Germania sobre sua finalidade, alguns acreditam que seja criticar a moral decadente romana pela oposição aos bons costumes dos primitivos germanos, outros, que seja instruir, outros ainda, que este seja um texto satírico para ironizar o fracasso dos romanos em conquistar a região. Mendell (1957), por exemplo, não pensa que o objetivo com essa obra tenha sido o de apresentar os germanos como 'bons selvagens', modelos para os depravados romanos:

Em Germania há uma possibilidade menor de se permitir esta tendência (ácido vitupério do presente), mas está suficientemente em evidência para ter levado mais de um crítico a colocar Germania na categoria dos escritos satíricos e a acreditar que seu principal objetivo era mostrar o contraste entre o pervertido romano e o nobre selvagem. Esta teoria dificilmente pode ser aceita: o fato é que Tácito não faz nada além de apresentar a situação como era, quando ele conta sobre ficar sentado ano após ano no senado e ver os melhores dentre seus amigos conservadores perseguidos pelo imperador enquanto arrogantes sem valor se desenvolviam.

Também desta ideia compartilha Leoni, de acordo com o exposto no prefácio à tradução de Germania de Stevenson (1952), versão brasileira mais recente da obra. No entanto, ao invés da finalidade política proposta por Mendell, Leoni vê nesta obra de Tácito 
uma finalidade meramente informativa, pois o interesse do autor de Germania, segundo ele, residia no "conhecimento real" dos povos germânicos:

Pelo que diz respeito, porém, à Germânia, não me parecem absolutamente acertadas as observações comuns lidas em todos os tratados de literatura latina e que se repetem com monótona precisão: Tácito quis comparar os costumes corrompidos dos romanos com os primitivos e rudes, mas sadios, dos antigos povos germânicos. (...) Não é a comparação, mas o conhecimento real daqueles povos o que interessava a Tácito: na Germânia não encontramos uma tese política, sim uma finalidade informativa.

A ausência de prefácio, normalmente presente nas obras de historiografia, colabora para a existência de interpretações diversas, pois é neste momento que o historiador define a matéria a ser tratada, explica sua importância, reflete sobre a história e sobre a metodologia historiográfica e explicita sua posição, como nos lembra Rives (TACITUS, 2002). Como exemplos, citamos o prefácio de Ab Urbe Condita de Tito Lívio, o prefácio da Guerra de Jugurta, de Salústio e Agricola de Tácito. No primeiro, Tito Lívio denuncia a modalidade de história que praticará, a universal:

(1) Conseguirei a recompensa do trabalho se registrar a história do povo romano, desde os primórdios da Cidade ${ }^{24}$

E ainda teorizando a história, escreve:

\footnotetext{
${ }^{24}$ Facturusne operae pretium sim si a primordio Vrbis res populi Romani perscripserim (...). In: NOVAK, M. DA G.; NERI, M. L.; PETERLINI, A. A. (org.). Historiadores latinos: antologa bilíngue. 3. ed. São Paulo: Martins Fontes, 1999.
} 
(10) O que é particularmente salutar e fecundo no conhecimento dos fatos é olhar atentamente as lições de cada exemplo, constantes de um documento claro: aí se pode encontrar o que imitar para si e para sua república; aí, o que evitar - indigno pelo começo, indigno pelo desfecho. ${ }^{25}$

No prefácio de Guerra de Jugurta, em IV. 1, Salústio faz sua proposição:

Tenho em mente escrever sobre a guerra que o povo romano travou com Jugurta, rei dos númidas, primeiro porque foi grande e cruel, e a vitória foi cheia de alternativas; depois, porque foi então que pela primeira vez se resolveu enfrentar a arrogância da nobreza (...) 3. Mas antes de me dispor a tal narrativa farei um pequeno retrospecto que irá esclarecer e melhor evidenciar o conhecimento de todos os fatos. ${ }^{26}$

E em Agricola, Tácito elabora um prefácio onde reflete sobre a virtude, a tirania, a história e a liberdade política.

Virtudes são mais apreciadas naquelas épocas em que surgiram, mas nestes tempos, mesmo para escrever sobre a vida de um homem que já está morto, eu tive de pedir permissão.

\footnotetext{
${ }^{25}$ Hoc illud est praecipue in cognitione rerum salubre ac frugiferum, omnis te exempli documenta in inlustri posita monument intueri; inde tibi tuaeque rei publicae quod imitere capias, inde foedum inceptu foedum exitu quod uites. In: NOVAK, M. DA G.; NERI, M. L.; PETERLINI, A. A. (org.). Historiadores latinos: antologa bilíngue. 3. ed. São Paulo: Martins Fontes, 1999.
}

${ }^{26}$ SALÚSTIO. A conjuração de Catilina. A guerra de Jugurta. Tradução de A. S. Mendonça. Petrópolis: Vozes, 1990. 
(...) a perseguição atingiu não apenas os autores, mas também seus livros.

(...) Eles imaginaram, sem dúvida, que naquelas labaredas desapareceriam a voz do povo, a liberdade do Senado e a consciência da humanidade.

e assim como as gerações passadas testemunharam os maiores excessos da liberdade, nós temos os extremos da escravidão.

Mas depois de tudo eu não devo me arrepender da tarefa de registrar nossa passada escravidão e testemunhar nossas bênçãos presentes, mesmo com uma língua destreinada e vacilante.

Quanto à interpretação de Germania como texto que visa ao rebaixamento dos romanos pela comparação com os nobres germanos, esta embasa-se nos contrastes traçados ao longo do texto por Tácito entre romanos e germanos, mas principalmente naqueles entre germanos e outro(s) povo(s) que não é (são) nomeado(s) e que pode ser tomado por Roma, pois são muito mais freqüentes e incisivos àqueles poucos em que explicitamente se diz in morem nostrum (6.3) ou in nostrum morem (16.2), como vimos na quarta parte da primeira sessão de nossos comentários (p.86 e 87). Mas como também já sabemos, o enaltecimento do estado primitivo era constante em textos etnográficos e a comparação do povo sobre o qual se escreve com o seu próprio servem para fornecer subsídios para a compreensão dos leitores. Entretanto, por escolher se enquadrar nesta tradição, Tácito poderia estar acobertando suas reais intenções de criticar os maus hábitos romanos pelo elogio da moral germana.

A falta de prefácio, supramencionada, combinada com o fato de que na tradição romana etnografias eram tipicamente digressões em histórias e não monografias, sugeriu a alguns estudiosos, de acordo com Rives (TACITUS, 2002), a ideia de que Tácito escrevera Germania como um estudo preliminar para Histórias e não como uma obra independente 
(RIVES, 1999, p. 48-49). Um destes pesquisadores foi Paratore (1962) ${ }^{27}$, mas esta hipótese não recebeu aceitação geral, visto que a apresentação dos germanos nas duas obras é marcadamente diferente, como vimos na segunda parte da primeira seção desses comentários (p. 76).

Perret sugere precaução ao avaliar as informações em Germania, pois estas podem corresponder a um fato verdadeiro sobre os germanos, comprovados pela arqueologia, por exemplo, ou a um lugar comum da tipologia etnográfica, usado para falar de um povo sobre o qual não se tem notícias autênticas, com base no que foi observado de um outro povo TACITE, 1949). Tácito diz que os germanos cultuavam Mercúrio (parágrafo 9), e assim faziam os gauleses de César (VI, XVIII, 1) e os trácios de Heródoto (V, 7); também diz que os germanos deliberavam em dois momentos, primeiramente bêbados e depois sóbrios, tal como os persas de Heródoto (I, 133). No entanto, a recorrência de um mesmo costume em mais de um povo não significa, necessariamente, que a informação seja autêntica a apenas um deles. Como bem nos lembra Perret, a etnografia moderna ensina que hábitos muito parecidos são observados em povos bem diferentes e distantes (TACITE, 1949).

Muitas notícias em Germania têm sua autenticidade questionada por causa de discrepâncias criadas pelo próprio autor do texto, segundo Perret (TACITE, 1949, p. 23), a saber: em IX, 3, Tácito nos faz crer que os germanos, por não entalharem estátuas cultuais, tinham de seus deuses uma noção livre de todo antropomorfismo (ceterum nec cohibere parietibus deos neque in ullam humani oris speciem assimulare ex magnitudine caelestium arbitrantur), mas em XLIII, 4-5 ele fala de deuses que eram venerados como jovens homens (ut iuvenes venerantur); em IX, 3 ele nos conta que os germanos não possuíam templos, mas no livro I, LI, 2 dos Anais há o relato da destruição de um desses templos; em V, 4 ficamos sabendo que moedas preferem e em XLII, 2 que, com prata, se pode contar com eles, quando

\footnotetext{
${ }^{27}$ Non vidi
} 
já foi dito que os germanos não se importam com ouro ou prata (parágrafo 26). Perret levanta a hipótese de que Tácito teria sido vítima de seu julgamento moralizante e criticado a riqueza ostentatória dos templos de seus concidadãos (TACITE, 1949). Nós pensamos que estas passagens tidas como contraditórias podem ser, apenas, aparentemente contraditórias, por terem outro significado em um contexto mais amplo.

Outra razão para Tácito ter elegido a etnografia para servir de estrutura para Germania, de acordo com Rives, teria sido a oportunidade para discutir assuntos morais e sociais, pois esse gênero, ou como pensamos que seja, espécie historiográfica, tradicionalmente servira como fórum para esse tipo de discussão (TACITUS, 2002). Afirma Rives (TACITUS, 2002, p. 51): “A etnografia funcionou quase desde seu surgimento como um trampolim para observações sobre a civilização e a corrupção que ela poderia vincular”. E a corrupção moral, como percebemos ao longo de todos os seus escritos, é uma preocupação recorrente de Tácito. Ainda segundo Rives, as observações de Tácito, principalmente aquelas sobre os costumes sexuais (parágrafos 18 e 19), levou alguns a proporem que seu objetivo em Germania era confrontar a degeneração de seus concidadãos com uma imagem imaculada dos germanos, mas esta ideia como interpretação geral do texto seria insuficiente (ver capítulo I. 4 deste trabalho). Consideramos esta interpretação, da maneira como é apresentada, sobre o que teria levado Tácito a escolher a etnografia, superficial e incompleta, já que o fato deste autor ter escolhido outras espécies historiográficas, antes e após a escrita de Germania, para compor as demais obras não o impediu de levantar, refletir e criticar hábitos morais, ou seja, a estrutura etnográfica era dispensável. Entretanto, se a intenção de Tácito fosse, como pode ter sido, disfarçar seus julgamentos morais sobre os romanos sob o véu das características típicas da tradição etnográfica, encontraríamos mais pertinência nessa justificativa pela opção da etnografia. 
Levando em consideração o contexto histórico em que se insere essa obra, algumas hipóteses sobre a intenção de Tácito ao elaborar um estudo dedicado ao povo germano em particular são levantadas. Germania é escrita em 98 d. C., dois anos após a morte de Domiciano, quem se dizia conquistador da Germânia, e quando Trajano comandava as tropas no Reno. Mas a tentativa de se perfazer a conquista do território germânico já vinha de tempos atrás e a cada derrota de um imperador, maior tornava-se o desafio e a glória resultantes dessa dominação. De 12 a. C. a 9 d. C., sob Augusto, foram empreendidas batalhas na tentativa de conquistar a Germânia. Mas após o massacre das legiões de Varo em 9 d. C. criou-se uma política de restrição da expansão imperial, a qual foi desobedecida por Cláudio e outros após a dinastia flávia. O título Germanicus então, que foi primeiramente atribuído a Druso pelo senado, em reconhecimento aos seus feitos na região, foi adotado por todos seus descendentes imperiais, Cláudio, Calígula e Nero, e tornou-se um sinal de status imperial. E Tácito, em Histórias I, 62, nos relata que em 69 d. C. as legiões do Reno conferiram a seu general Vitélio, após proclamarem-no seu imperador, o título Germanicus (nomen Germanici Vitellio statim additum).

Ao longo do parágrafo 37 de Germania, Tácito aponta para a ameaça que os germanos representaram para a expansão romana durante os duzentos e dez anos de tentativa nesse sentido, pois sua liberdade os impelia a resistir à subjugação; e afirma ainda que "nem os samnitas, nem os cartagineses, nem os hispanos, nem os gauleses, nem os partos nos deram mais lições".

Rives nos informa que alguns estudiosos, como Reitzenstein em $1914^{28}$, argumentaram que essa obra era um panfleto político, cuja intenção era chamar a atenção para a ameaça dos não-conquistados germanos e requerer de Trajano a concretização das promessas de Domiciano (TACITUS, 2002). Já Syme (1958) pensa que "Não cabia ao

\footnotetext{
${ }^{28}$ REITZENSTEIN, R. (1914) Bemerkungen zu den kleinen Schriften des Tacitus. In: Nachrichten von der königlichen Gesellschaft der Wissenschaften zu Göttingen, Phil.-hist. Klasse. p. 226-76. (Non vidi)
} 
consular Cornélio Tácito bancar o mentor de um imperador militar. (...) Era melhor para um senador abster-se de dar conselhos sobre política externa e militar. Ele poderia incorrer em erros de tática ou julgamento ou ambos".

Porém, o entrave militar foi tão grande e a conquista tão árdua de se perpetrar que marcou definitivamente a história romana, e para Rives talvez Tácito estivesse mesmo mais interessado na questão histórica resultante (TACITUS, 2002).

Ainda consideraremos outro ponto de vista sobre a obra. Ao descrever a região da Germânia e os costumes da vida social de seus habitantes, Tácito teria "conquistado" esse território, feito o que todos os imperadores até então haviam falhado em conseguir, por incorporá-lo ao mundo literário romano. Essa linha de raciocínio provém de Nicolet (1991), quem propôs que o controle simbólico do espaço poderia ser na época tão importante para os romanos quanto a verdadeira conquista. Para chegarmos a essa conclusão, basta a lembrança da propaganda política de Domiciano sobre a conquista da Germânia na cunhagem de suas moedas, ao criar duas novas províncias da Germânia e ao trocar o nome do mês de setembro para "germânico", informação esta provinda da vida de Domiciano XIII, 3, de Suetônio: "Tendo assumido para si o epíteto "Germânico" após dois triunfos, renomeou o mês de setembro e outubro a partir de sua denominação "Germânico" e "Domiciano", porque tomou o poder com um e nasceu com o outro" ${ }^{29}$. Entretanto, não pensamos ser adequada a aplicação do princípio de Nicolet a essa questão, apesar de acreditarmos ser uma possibilidade válida. Se o controle simbólico do local fosse realmente mais importante que a conquista de fato, os romanos não teriam tentado conquistar a Germânia com tanto empenho. Foi por todas as tentativas terem sido debalde que apenas restou a opção de se forjar a imagem de uma realidade outra, a fim de receber os louros. Independente disso, o historiador Tácito

\footnotetext{
${ }^{29}$ Tradução nossa do latim: post autem duos triumphos Germanici cognomine assumpto Septembrem mensem et Octobrem ex appellationibus suis Germanicum Domitianumque transnominauit, quod altero suscepit imperium, altero natus esset.
} 
seguramente conseguiu ter o controle sobre a Germânia, pois a recriou dentro do universo da literatura, em um aparente retrato fiel.

Por fim, concluímos que a variada gama de possibilidades de leitura de Germania são consequências do prisma pelo qual cada estudioso a observou e/ou acreditou que devesse ser observada. Por não poderem comprovar a impropriedade de outro ponto de vista, criaram um leque de possibilidades das quais podemos nos utilizar para observarmos Germania de vários ângulos, condição que só existe porque a obra é de tal forma engendrada que fornece oportunidade para tanto.

\section{2 Germania e Agricola: um programa comum}

Como foi visto acima, há estudiosos que identificam Germania, e também Agricola, como projetos preliminares de Tácito, nos quais ele experimentou as técnicas que necessitaria para obras mais ambiciosas. Em Agricola, Tácito faz uma mistura insólita de encômio e história, assim como cria Germania com duas partes distintas, que representam, na verdade, uma combinação da tradição etnográfica com a tradição periegética. A diferença entre uma e outra obra é que na primeira, encômio e história misturam-se ao longo do texto, e na segunda, etnografia e periegese estão claramente separadas.

Rives aponta para a dificuldade de se determinar a extensão para a qual Tácito teve precedentes para essa combinação de Germania, indicando que o relato de Heródoto dos citas (IV, 5-82) fornece um paralelo geral, mas sua organização é muito diferente, e conclui que a etnografia africana de Salústio em Bellum Iugurthinum, XVII-XIX, que termina com um 
breve resumo geográfico, estabeleça talvez um paralelo mais próximo, ainda que em uma escala muito menor (TACITUS, 2002).

Tácito utilizou temas e gêneros que não eram novos, entretanto foi um escritor experimental e inovador pela maneira como os trabalhou, criando obras totalmente inusitadas. Para Momigliano (2004, p. 163), não foram apenas Agricola e Germania suas obras experimentais; a experimentação é uma característica desse historiador e perpassa por todas suas obras "até em seus escritos históricos mais maduros" e que isso o tornou "um dos historiadores da antiguidade mais experimentais", comparável somente a Xenofonte, que tentou a biografia, a novela histórica, a história militar com elementos autobiográficos, a simples narrativa histórica e a coleção de ditames filosóficos. E Momigliano (2004) ainda afirma: "Superficialmente, Tácito não é multifacetado. Ele tentou apenas a biografia, a etnografia, a discussão histórica sobre o declínio da eloqüência e, finalmente, a simples narrativa analista. Mas quase todos os seus experimentos são complexos”.

Concordamos com Momigliano nesse ponto, que a experimentação é uma característica que Tácito imprime em todas as suas obras, não só em Germania e Agricola, as quais são comumente vistas dessa forma, talvez pelo grau de inovação ser mais presente, principalmente em Germania. No entanto, nenhum escrito de Tácito é exatamente aquilo que se espera que seja; os Anais não são uma simples narrativa analítica, aproximam-se muito das Histórias e contam até com digressões, já as Histórias apresentam um cenário de guerra civil em que os líderes militares não mais importantes, ou até poderíamos dizer com Momigliano, menos importantes, que os soldados, os provinciais e a plebe romana.

Para Syme (1958), o objetivo de Agricola está além de sua preocupação com a vida e elogio ao sogro de Tácito: “É um documento da literatura política romana, um manifesto para o imperador Trajano e a nova aristocracia imperial”. Por Rives (TACITUS, 2002) somos 
informados da também interpretação política de Agricola e Germania de Nesselhauf ${ }^{30}$, quem argumentou vigorosamente que essas duas obras compartilhavam um programa comum; com Agricola Tácito visava celebrar as conquistas de seu sogro, as quais Domiciano havia intencionalmente desvalorizado para que elas não ofuscassem sua própria vitória na Germânia, e com Germania Tácito buscava refutar as reivindicações de Domiciano pela descrição dos germanos como eles realmente eram. Pelo prefácio de Agricola, que vimos na seção anterior, percebemos a forte desaprovação de Tácito com relação às atitudes déspotas de Domiciano e poderíamos chegar à interpretação de Nesselhauf se lembrarmos do que Tácito disse sobre a função da história em Anais III, 65: "Estou persuadido de que o principal objetivo da história é o de preservar as virtudes do esquecimento e unir às palavras e ações perversas o medo da infâmia e da posteridade".

No entanto, Rives (TACITUS, 2002) chama a atenção para Germania, 30, quando Tácito trata da surpreendente e admirável natio dos catos: "Este povo possui corpos mais robustos, membros trabalhados, feição ameaçadora e maior vigor de espírito. Eles têm grande raciocínio e sagacidade, que os destaca dentre os germanos"; como os catos eram objeto das campanhas de Domiciano, a intenção não poderia ser desacreditá-lo, já que diante de tão amedrontador e poderoso inimigo a vitória sobre ele tornaria mais glorioso o venccedor. Então, Rives sugere que se entenda esse programa comum como um louvor a Trajano, um homem virtuoso como Agrícola e que empregara seus esforços para a glória de Roma; assim, uma obra etnográfica sobre o inimigo a ser derrotado daria a Trajano um panorama geral da questão e depois engrandeceria sua conquista.

\footnotetext{
${ }^{30}$ NESSELHAUF, H. (1952). Tacitus and Domitian. In: Hermes, n. 80, p. 222-45, reprinted in: V. Pöschl (ed.). Tacitus. p. 208-40.
} 


\section{CONSIDERAÇÕES FINAIS}

Germania escapa a uma definição genérica rígida, dada a variada riqueza de sua composição e unicidade na literatura historiográfica. Sua estrutura fundamental é construída com base na tradição etnográfica: a primeira metade, que se estende do parágrafo 1 ao 27 , aproxima-se mais de uma monografia etnográfica e a segunda, que se estende do parágrafo 28 ao 46, segue a linha periegética. Mas a etnografia, a despeito da origem grega do nome, não foi considerada entre os antigos gregos e romanos um gênero literário e desenvolveu-se principalmente como acessório de obras históricas, as digressões etnográficas. Desta forma, os moldes de Germania são sobremaneira incomuns à produção literária de então, e mesmo comparando-a às monografias tradicionais, como Aigyptiaca de Helânico de Lesbos e Lydiaka de Xanto, essa obra de Tácito diferencia-se pela carência de material mítico e geográfico. Em linhas gerais, e pelo que já foi discutido, pensamos que Germania seja uma monografia histórica com viés etnográfico.

A primeira seção de Germania apresenta os principais tópicos constantes em um texto etnográfico: as origens de um povo, suas características físicas e costumes religiosos, sociais e militares; e as fronteiras do território, sua natureza e topografia, seu clima e recursos. Ademais, faz uso de teorias típicas dessa tradição, como o reflexo no tipo físico e nas características psicológicas de um povo das peculiaridades da região que habita, e uso também de especificidades da escrita etnográfica. Elementos típicos tanto em monografias quanto em digressões etnográficas. Já a segunda seção de Germania traz uma lista das nationes da gens germana. Por que não pensar então em Germania como uma digressão para Histórias de Tácito, já que seu início é abrupto, sem qualquer proêmio, e sua natureza monográfica é insólita? A abertura de Germania retoma a abertura da monografia histórica De 
Bello Gallico de César; o retrato dos germanos no livro IV das Histórias dista muito de sua caracterização em Germania e, além do mais, a experimentação é uma constante no conjunto de obras de Tácito, como bem vemos em Agricola, uma mistura de encômio e história. Segundo aponta Rives, Germania não é a anomalia que pode parecer à primeira vista, mas claramente apresenta as mesmas preocupações literárias, morais e políticas que caracterizam suas outras obras (TACITUS, 2002).

Portanto, como monografia etnográfica, diversas hipóteses sobre a finalidade da obra foram levantadas por estudiosos, algumas mais prováveis, outras menos. A hipótese aventada por Leoni na introdução à mais recente versão acadêmica em português de Germania, feita no Brasil por Stevenson em 1952, por exemplo, é muito pouco provável. Ele considera que a finalidade de Germania seja meramente informativa, pois o interesse de Tácito residia no “conhecimento real” dos povos germânicos, algo que não combina com o estilo taciteano apresentado em suas outras obras. Entretanto, a grandeza dessa obra menor de Tácito reside, principalmente, no modo de costura do texto e arquitetura do todo, que sustenta um amplo número de possibilidades de leitura. Pensamos que uma boa interpretação para a obra, se nos fosse questionado, resultaria da combinação das hipóteses, a nosso ver, mais prováveis: Tácito estaria interessado em tratar essa questão histórica marcante, o grande entrave militar imposto aos romanos pelos germanos, e teria escolhido a etnografia para servir de estrutura a Germania pela oportunidade que dava de discutir assuntos morais e sociais de modo mais velado e porque, ao mesmo tempo, explicaria a causa de tão significativo impasse pela análise das características desse povo, que ensinara mais lições a Roma que qualquer outro inimigo, o que serve de alerta. Ao final, Tácito teria "conquistado" os germanos ao inclui-los na literatura romana.

Há, outrossim, a presença de outras espécies historiográficas e gêneros literários, como a épica, que aparecem normalmente pela retomada por Tácito da construção de algum trecho e 
da ideia de alguma passagem e de sua inserção no corpo de Germania. O objetivo disso é trazer de pronto à mente do leitor a memória do trecho original e sua significação; e com isso também se vincula o texto a esse gênero, como à elevação e caraterísticas próprias da épica. 


\section{BIBLIOGRAFIA}

\section{Edições de Germania e demais obras de Tácito}

TACITUS. Agricola, Germania, Dialogus. Translated by M. Hutton, W. Peterson. Cambridge: Harvard University Press, 2006. 357 p.

. Germania, Agricola, Dialogus de oratoribus. Lipsia: Teubner, 1964. 128 p. Ericus Koestermann edidit. Vol. II.

. Germânia (De origine et situ germanorum). Tradução de João Penteado Erskine Stevenson. São Paulo: Brasil editora, 1952. (Biblioteca de autores célebres, 24).

. Oeuvres completes de Tacite. Traduites en français avec une introduction par J.

L. Burnouf. Paris: Garnier, [s.d.].

\section{Outras fontes antigas}

ATHENAEUS. The Deipnosophists. Cambridge: Harvard University Press, 1957.

CAESAR. The Gallic War. Cambridge: Harvard University Press, 1986.

DIODORO DE SICILIA. Biblioteca Histórica. Madrid: Editorial Gredos, 2001.

MÜLLER, C. (ed.). Geographi graeci minoris. Paris: Firmin-Didot, 1882. 
HERODOTUS. The Histories. New York: W. W. Norton \& Company, 1992.

JUSTINO. Epítome de las "Historias Filípicas" de Pompeyo Trogo. Prólogos. Pompeyo

Trogo: Fragmentos. Madrid: Editorial Gredos, 1995 (Biblioteca Clásica Gredos, 212).

LIVY. Livy (In fourteen volumes). Cambridge: Harvard University Press, 1988.

LUCRÈCE. De la nature. Paris: Les Belles Lettres, 1935.

POLYBIUS. The Histories. Cambridge: Harvard University Press, 1954.

POSIDONIUS. I- The Fragments. Cambridge: Cambridge University Press, 1989. 2 ed.

(Cambridge classical texts and commentaries, v. 13). Edited by L. Edelstein; I. G. Kidd.

SALLUST. Sallust (Complete Work). Cambridge: Harvard University Press, 1985.

SUETONIUS. Suetonius. Vol. II. Cambridge: Harvard University Press, 1992.

VIRGIL. Eclogues, Georgics, Aeneid I-VI. Cambridge: Harvard University Press, 1994. v. 1. Aeneid VII-XII, The minor poems. Cambridge: Harvard University Press, 1986. V.

2.

\section{Trabalhos modernos}

BENARIO, H. W. Tacitus and the Fall of the Roman Empire. In: Historia: Zeitschrift für Alte Geschichte, Bd. 17, H. 1, p. 37-50, Jan. 1968. 
FETTES, J. Tacitus, Germania 19.1. In: The Classical Quaterly, New Series, v. 27, n. 2, p. 469-470, 1977.

FRASER, P. M. Aspects of alexandrian literature. In: Ptolemaic Alexandria. Oxford: Clarendon Press, 1972. p. 495-553.

GERBER, A.; GREEF, A. Lexicon Taciteum. Hildesheim: Georg Olms, 1962.

GUDEMAN, A. The sources of the Germania of Tacitus. In: Transactions and Proceedings of the American Philological Association, v. 31 (1900), p. 93-111.

JACOBY, F. Die Fragmente der Griechischen Historiker. Leiden: E. J. Brill, 1986.

LEE, G. M. Tacitus, Germania 36.1. In: The Classical Quaterly, New Series, v. 18, n. 2 (Nov., 1968), p. 382-383.

MARINCOLA, J. (Ed.) A companion to Greek and Roman historiography. Oxford: Blackwell Publishing, 2007.

MELLOR, R. Tacitus. New York: Routledge, 1993.

MENDELL, C. W. Tacitus: The man and his work. New Heaven: Yale University Press, 1957. $397 \mathrm{p}$.

MOMIGLIANO, A. As raízes clássicas da historiografia moderna. Bauru: EDUSC, 2004.

NICOLET, C. Space, Geography, and Politics in the Early Roman Empire. Michigan: The University of Michigan Press, 1991.

NORDEN, E. Die Germanische Urgeschichte in Tacitus Germania. Leipzig: B. G. Teubner, 1920. 
NOVAK, M. DA G.; NERI, M. L.; PETERLINI, A. A. (org.). Historiadores latinos: antologia bilíngue. 3. ed. São Paulo: Martins Fontes, 1999.

OAKLEY, S. P. Style and language. In: WOODMAN, A. J. (Ed.). The Cambridge

Companion to Tacitus. Cambridge: Cambridge University Press, 2009. p. 195-212.

SYME, R. Tacitus. Clarendon Press: Oxford, 1958.

TACITE. La Germanie. Texte établi et traduit avec une introduction par Jacques Perret. Paris: Les Belles Lettres, 1949.

TACITUS. Germania. Translated with introduction and commentary by J. B. Rives. Oxford: Clarendon Press, 2002. 346 p.

THOMAS, R. F. The Germania as literary text. In: WOODMAN, A. J. (Ed.).The Cambridge Companion to Tacitus. Cambridge: Cambridge University Press, 2009. p. 59-73.

TRÜDINGER, K. Studien zur Geschichte der griechisch-römischen Etnographie. Basel: Emil Birkhäuser, 1918. 